Natural Science Research Laboratory

\title{
Special Publications
}

Museum of Texas Tech University

Number 69

29 November 2018

\section{Bats OF SAINT LUGIA, Lesser ANTILles}

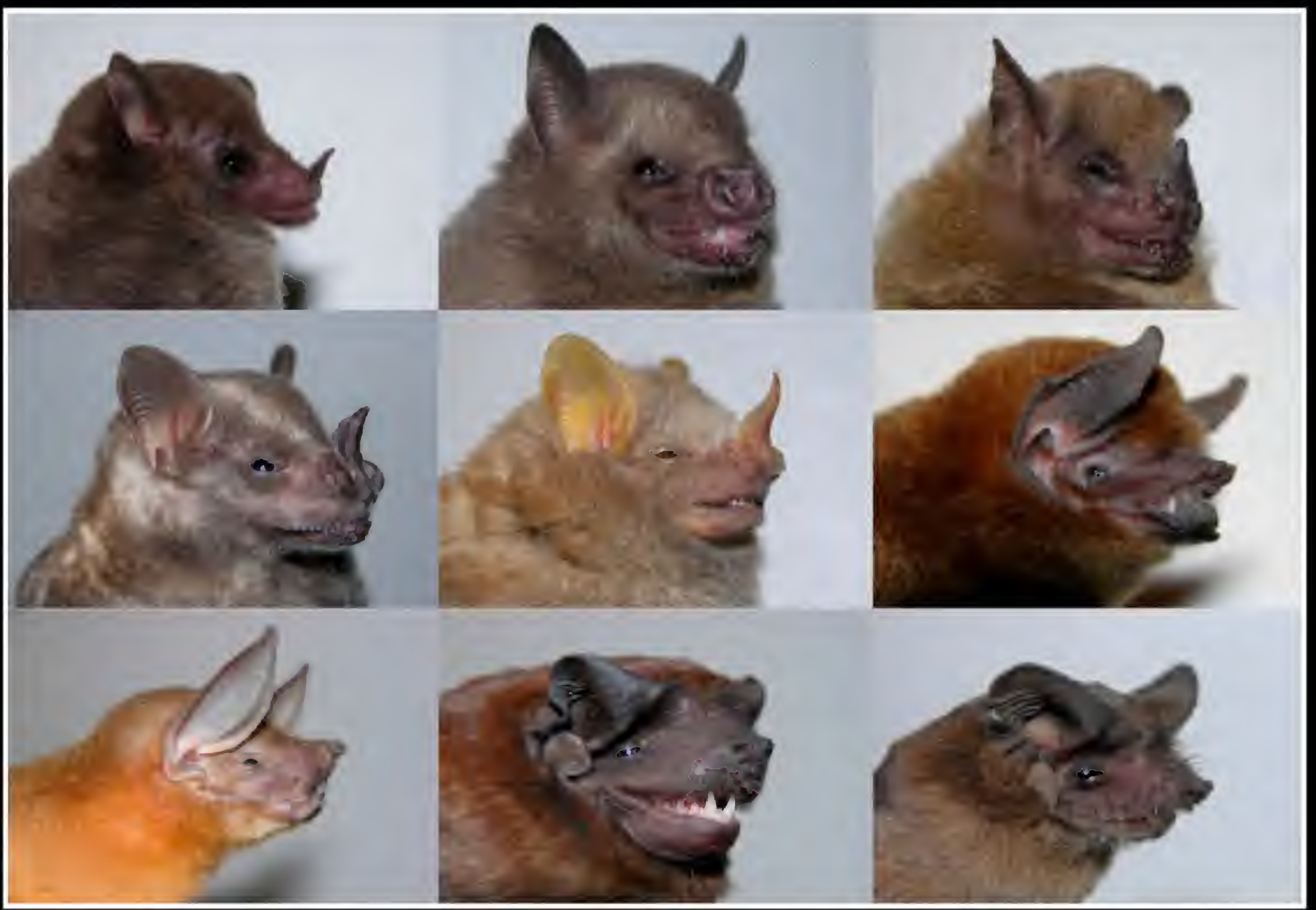

Scott C. PEDERsen, GaRy G. KWIEcinski, Hugh H. Genoways, Roxanne J. LaRsen, Peter A. Larsen, Carleton J. Phillips, and Robert J. Baker 
Front cover: The bats of Saint Lucia (from upper left to lower right): (row 1) Monophyllus plethodon, Brachyphylla cavernarum, Sturnira paulsoni; (row 2) Artibeus jamaicensis $\times$ schwartzi, Ardops nichollsi, Pteronotus davyi; (row 3) Noctilio leporinus, Molossus molossus, and Tadarida brasiliensis. Photographs by Gary G. Kwiecinski. 


\title{
SPECIAL PUBLICATIONS
} Museum of Texas Tech University

Number 69

\author{
Bats of Saint Lucia, Lesser Antilles
}

Scott C. Pedersen, Gary G. Kwiecinski, Hugh H. Genoways, Roxanne J. Larsen, Peter A. Larsen, Carleton J. Phillips, and Robert J. Baker 
Layout and Design: $\quad$ Lisa Bradley

Cover Design: $\quad$ Gary G. Kwiecinski

Production Editor: $\quad$ Lisa Bradley

Copyright 2018, Museum of Texas Tech University

This publication is available free of charge in PDF format from the website of the Natural Sciences Research Laboratory, Museum of Texas Tech University (nsrl.ttu.edu). The authors and the Museum of Texas Tech University hereby grant permission to interested parties to download or print this publication for personal or educational (not for profit) use. Re-publication of any part of this paper in other works is not permitted without prior written permission of the Museum of Texas Tech University.

This book was set in Times New Roman and printed on acid-free paper that meets the guidelines for permanence and durability of the Committee on Production Guidelines for Book Longevity of the Council on Library Resources.

Printed: $\quad 29$ November 2018

Library of Congress Cataloging-in-Publication Data

Special Publications of the Museum of Texas Tech University, Number 69

Series Editor: $\quad$ Robert D. Bradley

Bats of Saint Lucia, Lesser Antilles

Scott C. Pedersen, Gary G. Kwiecinski, Hugh H. Genoways, Roxanne J. Larsen, Peter A. Larsen, Carleton J. Phillips, and Robert J. Baker

ISSN 0149-1768

ISBN 1-929330-36-7

ISBN13 978-1-929330-36-2

Museum of Texas Tech University

Lubbock, TX 79409-3191 USA

(806)742-2442 


\title{
Bats of Saint Lucia, Lesser Antilles
}

\author{
Scott C. Pedersen, Gary G. Kwiecinski, Hugh H. Genoways, Roxanne J. Larsen, Peter A. Larsen, \\ CARLETON J. PHILLIPS, AND ROBERT J. BAKER
}

\begin{abstract}
Eight species of bat have been previously recorded from the island of Saint Lucia: Noctilio leporinus, Monophyllus plethodon, Artibeus jamaicensis, Brachyphylla cavernarum, Ardops nichollsi, Sturnira paulsoni, Molossus molossus, and Tadarida brasiliensis. Herein, we add a ninth species to the fauna-Pteronotus davyi. These nine species represent nine genera from four families: Noctilionidae, Mormoopidae, Phyllostomidae, and Molossidae. This fauna includes four trophic guilds: N. leporinus (piscivore/insectivore), M. plethodon (nectarivore/pollenivore), A. jamaicensis $\times$ schwartzi, B. cavernarum, A. nichollsi, and S. paulsoni (frugivores), and P. davyi, $M$. molossus, and T. brasiliensis (insectivores). Based on its geographic location, the bat fauna of St. Lucia is enigmatic in regard to species dispersal along the Lesser Antillean archipelago. Natalus stramineus and M. martiniquensis are present on Martinique immediately to the north, and Micronycteris buriri, P. fuscus, Glossophaga longirostris, and Artibeus lituratus are found on St. Vincent directly to the south, yet these six species are conspicuously absent on St. Lucia. Moreover, the St. Lucian population of Artibeus resides at the northern edge of a fascinating hybrid zone involving three species, $A$. jamaicensis, A. planirostris, and A. schwartzi. In light of these observations, we provide a framework for analyzing the biogeographical patterns of the regional fauna to see if there is something about St. Lucia that is unique. We posit that a number of complex geological and ecological factors account for the depauperate bat fauna observed on the island as well as the formation of the Artibeus hybrid zone in the southern Lesser Antilles.

Key words: biological invasion, Chiroptera, environmental disruption, hybrid swarm, Mammalia, natural dispersal, natural history, propagule, Pteronotus davyi, reproduction, Saint Lucia, species richness
\end{abstract}

\section{INTRODUCTION}

The first report of a bat from St. Lucia was by Dobson (1878) based on an adult male Molossus molossus in the British Museum (Natural History), which had been purchased from Miss R. Alexander. Subsequently, seven additional species of bat were collected on St. Lucia by several individuals, notably: $\mathrm{H}$. S. Branch in 1901 (NMNH) and J. L. Peters in 1925; J. Knox Jones, Jr., and C. J. Phillips in 1967 (KU); and J. J. Gulledge in 1971 (AMNH). Their voucher specimens are well reported in the literature (Dobson 1878; Miller 1902, 1913a, 1913b; Allen 1908, 1911; Andersen 1908; Shamel 1931; Jones and Schwartz 1967; Koopman 1968; Jones and Phillips 1970; Jones 1978; Swanepoel and Genoways 1978). In this study, we added the ninth species to the fauna-Pteronotus davyi.

Perhaps the most remarkable aspect of the bats of St. Lucia is that the resident population of Artibeus includes hybrids between $A$. jamaicensis and $A$. schwartzi (P. Larsen et al. 2010). Indeed, the island is located at the northern edge of an active hybrid zone among multiple species of Artibeus and therefore traditional taxonomic assignment of species-level status is problematic. The fauna also includes $S$. paulsoni, a species endemic to three southern Lesser Antillean islands, and $A$. nichollsi, endemic to the Lesser Antilles but not 
found on the southern islands of Barbados and Grenada. Two species-B. cavernarum and M. plethodon - are Antillean endemics with geographic ranges extending from Puerto Rico (Monophyllus appearing only as a fossil) in the Greater Antilles southward to the islands of St. Vincent and Barbados. Of those species occurring on St. Lucia, three ( $N$. leporinus, P. davyi, and $M$. molossus) have entered the Lesser Antilles directly from the South American mainland or via Trinidad, whereas the fourth species (T. brasiliensis) entered the islands from either the west via the Yucatan Peninsula or Nicaragua, or from Florida in the north.
Members of our research team first visited St. Lucia 26 to 28 August 1967 when C. J. Phillips and the late J. K. Jones, Jr., worked two sites in Dauphin and Gros Islet quarters. Subsequently the island was visited 24 to 26 May 1987, when H. H. Genoways and C. J. Phillips focused on the collection of Artibeus near Marigot Bay. We returned to the island to net additional bats on the following dates: 15 to 20 June 2007; 29 July to 3 August 2008; and 13 to 16 March 2009. It is the combination of these data that we report herein to elucidate the composition and relationships of the chiropteran fauna of St. Lucia.

\section{Methods ANd Materials}

Geophysical description of the study area.-The Lesser Antilles is a chain of volcanic islands that lie along the eastern edge of the Caribbean plate. This archipelago was initially formed by volcanic eruptions more than five million years ago (Newman 1965; Lindsay et al. 2002) and extends from the Greater Antilles, nearly to the coast of South America. Islands in the southern half of the Lesser Antilles were composed primarily of volcanic ejecta (Fig. 1).

Saint Lucia was formed approximately 2 million years ago, and its geological history has received considerable attention (Lindsay et al. 2002). The semicircular depression around the Soufrière- the Qualibou depression - was thought by many to be an ancient caldera (Wohletz et al. 1986). However, given that the spectacular Gros and Petit Piton were the remnants of two large dacitic lava domes formed no more than 300 thousand years ago, Roobol et al. (1983) and Wright et al. (1984) interpreted the Qualibou depression not as a caldera, but rather a large gravity slide. Another extremely violent phase of island building occurred at the Soufrière Volcanic Centre 40 to 20 thousand years ago when a series of major eruptions produced pyroclastic flows that surged southwards thus forming that southern end of the island (Wright et al. 1984; Lindsay et al. 2002). Wohletz et al. (1986) proposed that these eruptions came from the Qualibou depression itself, whereas others (Roobol et al. 1983; Wright et al. 1984) thought that these eruptions came from vents in the Central Highlands (Mt. Grand Magazin and Piton St. Esprit). There was a massive phreatic eruption in
1766 (Lefort de Latour 1787) and a flurry of phreatic activity from 1839 to 1843 (Breen 1844).

Saint Lucia is located in the Lesser Antilles, a chain of islands that extends from Sombrero to the north and to Grenada in the south. Saint Lucia is situated in the southern portion of this archipelago, $33.5 \mathrm{~km}$ south of Martinique and $46 \mathrm{~km}$ north of St. Vincent (Fig. 1). St. Lucia is $43.5 \mathrm{~km}$ long and $22.5 \mathrm{~km}$ wide. With a land area of 616 square $\mathrm{km}$, it is one of the larger islands in the Lesser Antilles. St. Lucia is characterized by very rugged mountainous terrain, dominated by a central ridge running almost the full length of the island, slowly rising to Mount Gimie (958 m) in the south. From this central ridge, valleys extend to either coast, some of which are broad with relatively large areas of flat land presently occupied by banana (see following section for scientific names of plant species discussed in text) plantations, including those at Cul-de-Sac and Roseau.

The island has a tropical marine climate characterized by a relatively uniform dry season from January to April and a rainy season from May to August, with usually sunny, warm weather from September to October. The mean annual temperature is approximately $26^{\circ} \mathrm{C}$ at sea level. Annual rainfall varies from 1.52 to $1.57 \mathrm{~m}$ in the north to 2.54 to $3.68 \mathrm{~m}$ in the mountainous interior of the south (Toussaint et al. 2009).

Historically, tropical storms and hurricanes are infrequent, with the majority passing to the north of Saint Lucia. From 1780 to 2010, 16 hurricanes and 46 


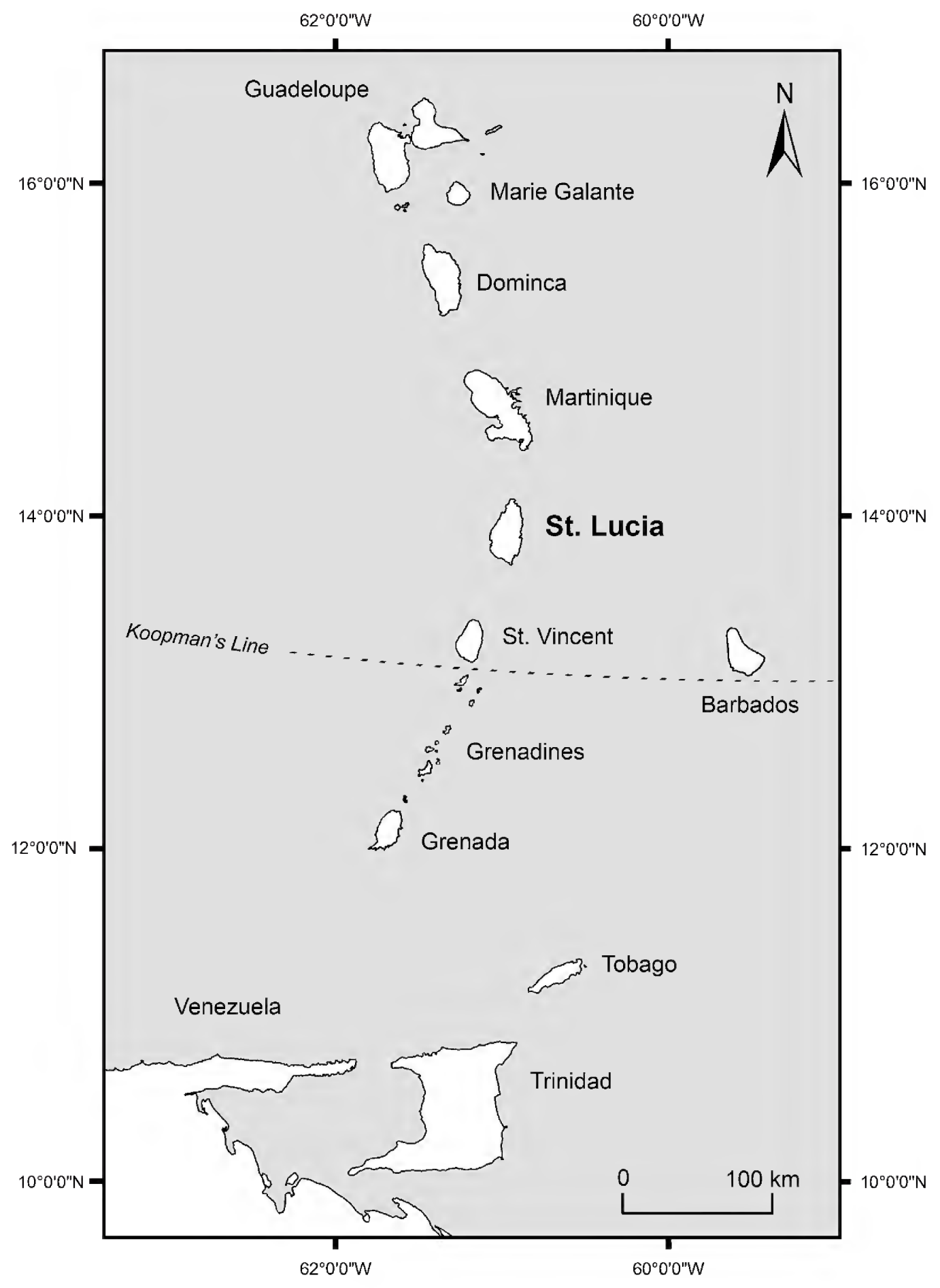

Figure 1. Map of the southern Lesser Antilles, Trinidad, and northern South America, showing the position of the island of Saint Lucia in relation to other islands and landmasses in the region. 
Special Publications, Museum of Texas Tech University

tropical storms have impacted the island. The strongest hurricane to hit St. Lucia in recent history was Hurricane Allen, a Category 4 storm $(202 \mathrm{~km} / \mathrm{hr}$ maximum wind speed), which passed just south of the Hewanorra International Airport on 4 August 1980. St. Lucia received catastrophic damage including: destruction of the banana crop, extensive damage to forests, the leveling of homes, and the deaths of at least 16 people. Hurricane Dean, a Category 2 hurricane $(175 \mathrm{~km} / \mathrm{hr}$ maximum wind speed), passed between St. Lucia and Martinique on 17 August 2007, after our 2007 field season. Martinique sustained the most damage from this storm, but St. Lucia lost $75 \%$ of its banana crop, which was a severe blow to the island's economy (Caribbean Hurricane Network 2015). Natural disturbances, such as landslides and hurricanes, explain why relatively few of the forest areas display a classic climax structure (Tomblin 1981; Daltry 2009; Graveson 2009).

Nearly $35 \%$ of St. Lucia is still under some form of forest cover that has been described in detail (Beard 1949; see also Clarke 2009; Daltry 2009; Graveson 2009; Morton 2009; Graveson and Smith 2013). The rain forests (moist forest) covered $20 \%$ of the island and occupied the higher elevations (typically above 250 $\mathrm{m}$ ) of the central spine of mountains extending from the Castries Water Works Reserve and Piton Flore area in the north across the narrow Barre de l'Isle corridor to the large blocks of forest to the south exemplified by the Edmund Forest Reserve (Isaac and Bourque 2001). These forests were characterized by trees such as candlewood, acomat boucan, bois de masse, laurier canelle, and bwapen mawon. Plantations of non-native trees, such as blue mahoe and Caribbean pine, have been placed around the boundaries of the forest reserves.

Further down the slopes was the lower montane rain forest, which was well developed on St. Lucia, with trees reaching $30 \mathrm{~m}$ in height in some areas. These forests were found in the lower reaches of Barre de l'Isle Ridge, Piton Flore, Dennery Water Works Reserve, Au Leon Peak, and Raillon Negres. Common trees of this forest type included bois de masse, balata chien, candlewood, bois cote, mountain palmetto, and palétuvier. This secondary rain forest was surrounded by disturbed habitat associated with abandoned agricultural lands, forest logged for timber, and areas damaged by tropical storms and hurricanes in the past. Breadfruit trees were often seen growing in these areas along with pioneer trees such as gumtree, maho kochon, and bwa kannon.

Of lesser importance to bats are the dry scrub woodlands that occupy the low-lying areas along the east and west coasts and the northern part of the island. In several places, these areas are degraded through human activity such as agriculture, grazing, roads, and settlements (Gonzalez and Zak 1996). The largest trees in these areas are white cedar and bay leaf, but two introduced trees dominate these woodlands, logwood and acacia. Among the bushes and small trees common in this habitat were rough-leaf velvetseed, blacktorch, and cup tree.

Plant names.-The following are the common and scientific names of plants discussed in the text: Acacia (Acacia nilotica), Acomat Boucan (Sloanea caribaea), Almond (Prunus dulcis), Balata Chien (Pouteria pallida), banana (Musa sp.), Bay Leaf (Pimenta racemosa), Bitterwood (Simarouba amara), Blacktorch (Erithalis fruticosa), Blue Mahoe (Hibiscus elatus), Bois Cote (Tapura latifolia), Bois de Masse (Licania ternatensis), Breadfruit (Artocarpus altilis), Buttercup Tree (Cochlospermum vitifolium), Bwa Kannon (Cecropia schreberiana), Bwapen Mawon (Magnolia dodecapetala), Candlewood (Dacryodes excelsa), Caribbean Pine (Pinus caribbea), Cocoa (Theobroma cacao), Coconut (Cocos nucifera), Cup Tree (Wedelia calycina), Guava (Psidium guajava), Guinep (Melicoccus bijugatus), Gumtree (Sapium caribaeum), Lansan (Protium attenuatum), Laurier Canelle (Phoebe elongata), Limes (Citrus latifolia), Logwood (Haematoxylum campechianum), Maho Kochon (Sterculia caribaea), Mango (Mangifera indica), Mountain Palmetto (Euterpe globosa), Nutmeg (Myristica fragrans), Palétuvier (Tovomita plumieri), pepper plant (Piper sp.), Rough-leaf Velvetseed (Guettarda sacabra), Soursop (Annona muricata), Swizzlestick Tree (Quararibea turbinata), Tree Ferns (Cyathea arborea), and White Cedar (Tabebuia heterophylla or T. pallida).

Collection of specimens. - We explored and collected specimens from two caves in 2007, Grace Cave and Soufrière Cave. However, field collection and sampling was accomplished primarily by ground level mist netting. We set 127 mist nets at 21 unique 
localities (Barre de l'Isle was sampled twice), during four different time periods: 24-26 May 1987; 14-20 June 2007; 28-31 July and 1-3 August 2008; and 12-16 March 2009. These nets were set at elevations ranging from 1 to $550 \mathrm{~m}$ and were equally distributed above and below $250 \mathrm{~m}$ in elevation. They were also equally distributed on the western (wet) and eastern (dry) halves of the island. Netting was conducted in a variety of habitats including naturally vegetated ravines or ghuts, access roads, trails, rivers, ponds, fruit plantations, forest plantations and reserves, botanical gardens, and other covered flyways. At each netting site, five to eight mist nets $(2.8,6,9,12$ or $18 \mathrm{~m}$ length by $2.8 \mathrm{~m}$ height) were set at 20 to $100 \mathrm{~m}$ intervals depending on local landscape features, i.e., width of access roads or rivers, forest edge, vegetated dry and wet ghuts, small fruit plantations, and freshwater ponds. Nets were opened near sunset (1800-1900 hr) and closed between 2200 and $2300 \mathrm{hr}$ each night, depending on weather and bat activity. Bats caught in nets were placed in holding bags until the end of the netting each night. Bats were subsequently examined for: weight $(\mathrm{g})$, length of forearm $(\mathrm{mm})$, reproductive condition, tooth wear, presence of ectoparasites, and scars.

For comparisons with our 1987 and 2007-2009 collections on St. Lucia, we drew additional netting data from similar survey efforts on both Martinique (Catzeflis et al., personal communication) and St. Vincent (Kwiecinski et al. 2018). These data were parsed into island-wide bat diversity and the diversity observed at netting locations that were located away from known roosts. The latter varied amongst the three neighboring islands (Martinique, 24; St. Lucia, 20; and St. Vincent, 28) as did the number of bats that were netted at these particular locations $(1,859,1,520$, and 1,679, respectively). However, netting locations on wet and dry (west versus east) sides of these islands $(\sim 13: 11$, $10: 10,14: 14)$ and the distributions of net sites above and below $250 \mathrm{~m}$ are comparable (12:12, 10:10, 14:14).

Minitab 16 (2010) provided standard statistics for each sample set examined and paired t-tests were utilized to test for differences between groups. Species curves were generated in JMP 12 (2015) and R was used in the multiple regression analysis ( $\mathrm{R}$ Development Core Team 2008).

Museum voucher specimens. - During the 20072009 surveys, we captured 1,624 bats, 1,248 of which were captured/released. We deposited 376 voucher specimens in the mammal collections of the Museum of Texas Tech University. We examined 72 bats (UNSM) that had been collected by two of the authors (HHG and CJP) in 1987. We examined 122 additional specimens that were collected before 1987 that were deposited in other museums: American Museum of Natural History, 2; Kansas Museum of Natural History, 32; and National Museum of Natural History, 88 (see Appendix). There are no fossil records of bats from this island.

\section{Systematic Accounts}

The species accounts that follow are arranged in systematic order (Simmons 2005; Baker et al. 2016; Cirranello et al. 2016). Given that the nine genera of bats recorded from St. Lucia are monotypic on the island, we refer to these taxa by genus, where pragmatic. These data are drawn from both the authors' inventory efforts on St. Lucia and data from museum specimens. A list of specimens and a list of additional records are included. Weights were determined with a digital balance and recorded in grams (g). Forearms were measured with digital calipers and recorded in millimeters (mm). All measurements of embryos are crown-rump length $(\mathrm{mm})$. Testes were measured for length $(\mathrm{mm})$. Distances were recorded in kilometers $(\mathrm{km})$ or miles as they appeared on original specimen tags. All elevations are reported in meters (m), unless specified otherwise. Length of forearms and cranial measurements were taken from museum vouchers following Hall (1946), except greatest length of skull included incisors, and length of forearm was the distance from the olecranon process of the elbow joint to the tip of the carpals with wing in the retracted position. 
Family Noctilionidae

\section{Noctilio leporinus mastivus (Vahl, 1797) Greater Fishing Bat}

Specimens examined (6).-Anse La Raye: Anse

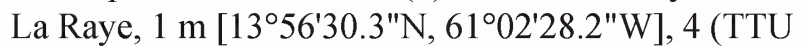
110080-83). Micoud: Canelles River, $1.5 \mathrm{~km} \mathrm{~S}$ Anse Ger, 10 m [134' $\left.59.6^{\prime \prime N}, 60^{\circ} 54^{\prime} 53.1^{\prime \prime W}\right], 1$ (TTU 110084). No Specific Quarter: no specific locality, 1 (NMNH 110922).

Additional records.- Soufrière: Edmund Forest Reserve (Clarke 2009). No Specific Quarter: no specific locality (Allen 1911).

This species represents a recent radiation within the genus Noctilio, having diverged from its sister species $N$. albiventris within the last million years (Pavan et al. 2013; Khan et al. 2014). Owing to the species' recent evolutionary history, studies focused on the intraspecific morphological and genetic variation of $N$. leporinus have resulted in conflicting taxonomic assessments. Davis (1973) identified three subspecies within $N$. leporinus $-N$. l. leporinus (distributed in South America east of the Andes Mountains, throughout Amazonia and the Guyana Shield); N. l. mastivus (distributed throughout Central America, the Caribbean, and in South America throughout Venezuela and along the western versant of the Andes Mountains into northern Ecuador), and N. l. rufescens (distributed in southern South America throughout Bolivia, Paraguay, northern Argentina and southern Brazil). However, genetic data presented in Pavan et al. (2013) and Khan et al. (2014) reveal two main lineages within $N$. leporinus, one corresponding to N.l. mastivus and the other to $N$. l. leporinus. To date, all specimens collected from within the range of $N$. l. rufescens are genetically indistinguishable from N. l. leporinus (Pavan et al. 2013; Kahn et al. 2014).

Phylogeographic data from $N$. leporinus indicates dual invasions into the Caribbean, with the Greater Antilles being colonized by Central American populations and the Lesser Antilles colonized by northern South American populations (Lewis-Oritt et al. 2001a, 2001b; Genoways et al. 2010; Pavan et al. 2013; Kahn et al. 2014). There was no clear genetic consensus regarding the appropriate subspecific taxonomy for southern
Lesser Antillean populations of $N$. leporinus. A putative hybrid zone between $N$. l. mastivus and N. l. leporinus was identified by Khan et al. (2014) in eastern Venezuela and the Guyana Shield, the regions from which southern Lesser Antillean populations presumably originated (Genoways et al. 2010; Khan et al. 2014). Additional research will be required to determine the extent of hybridization in mainland populations of $N$. leporinus and whether or not this hybrid zone has influenced southern Lesser Antillean populations. With respect to Caribbean $N$. leporinus, we recommend the usage of advanced genomic techniques to examine the evolutionary history of Greater Antillean and Lesser Antillean populations and to more precisely identify zones of secondary contact between $N$. l. mastivus and N. l. leporinus. Until such data become available, we provisionally retain $N$. l. mastivus for the St. Lucia population.

Table 1 presents length of forearm and seven cranial measurements for four males and two female Noctilio from St. Lucia. As is typical for this species, males averaged larger than females for all seven measurements. The average forearm and five of seven cranial measurements were not significantly different between the sexes. The zygomatic breadth and length of maxillary toothrow were significantly $(P \leq 0.05)$ larger in males than females. In comparison with measurements from other West Indian females (Davis 1973), measurements for females from St. Lucia were within ranges reported for the West Indies except breadth across the upper molars was smaller in the St. Lucia sample.

This species is widespread in the Antilles, being found in non-arid lowland and coastal regions and in major river basins (Hood and Jones 1984). H. S. Branch collected the oldest known specimen of Noctilio from St. Lucia in 1901 (NMNH 110922) from an unspecified locality. We collected Noctilio on St. Lucia at two localities, foraging over a coastal inlet in Anse La Raye on the west coast and the Canelles River on the east coast (Fig. 2).

At Anse La Raye, we placed three mist nets over the Petite Rivière de l'Anse La Raye, which was approximately $4 \mathrm{~m}$ wide, at the point it crossed under the coastal highway at the north edge of town (Fig. 3). Two 


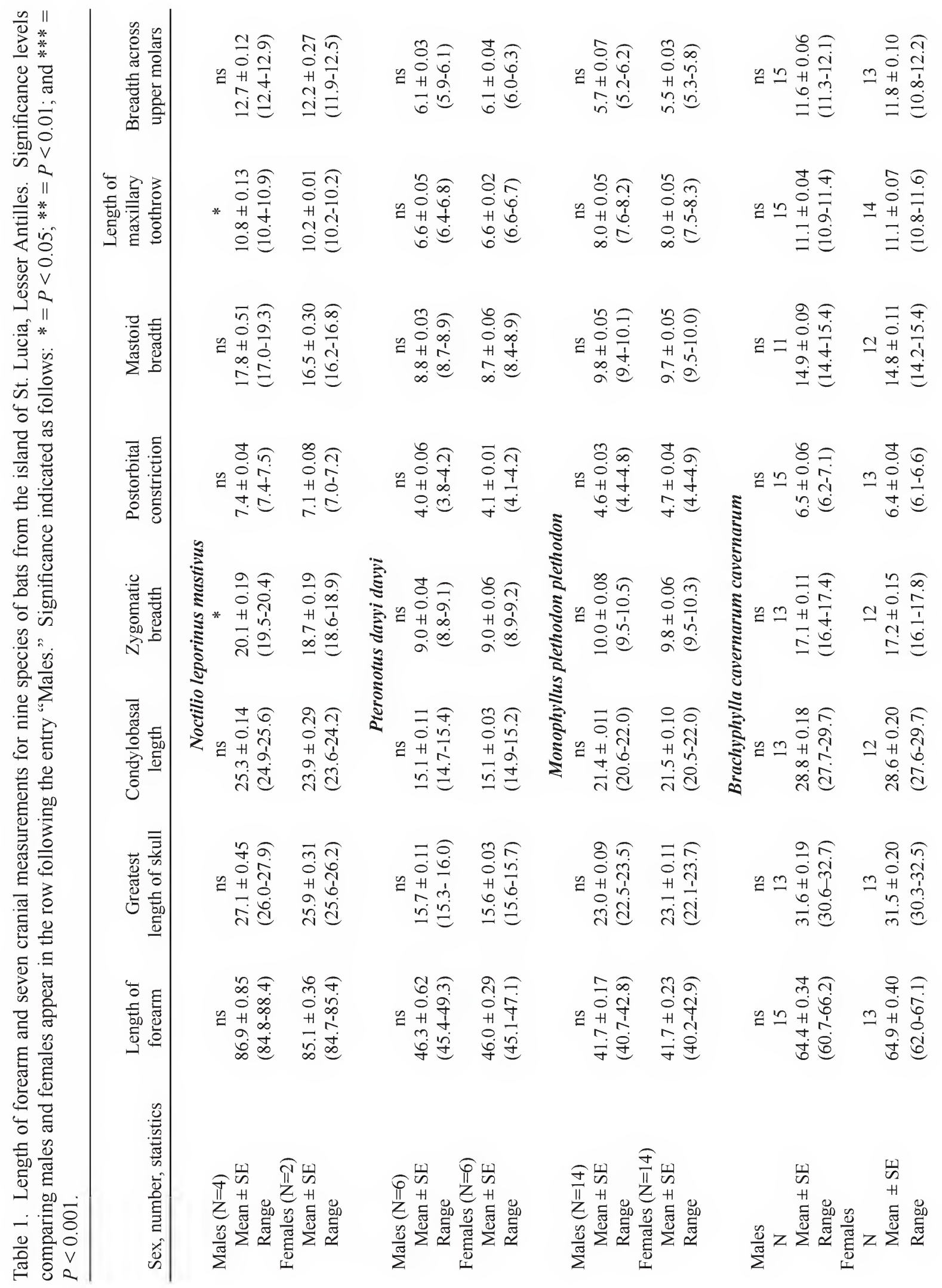




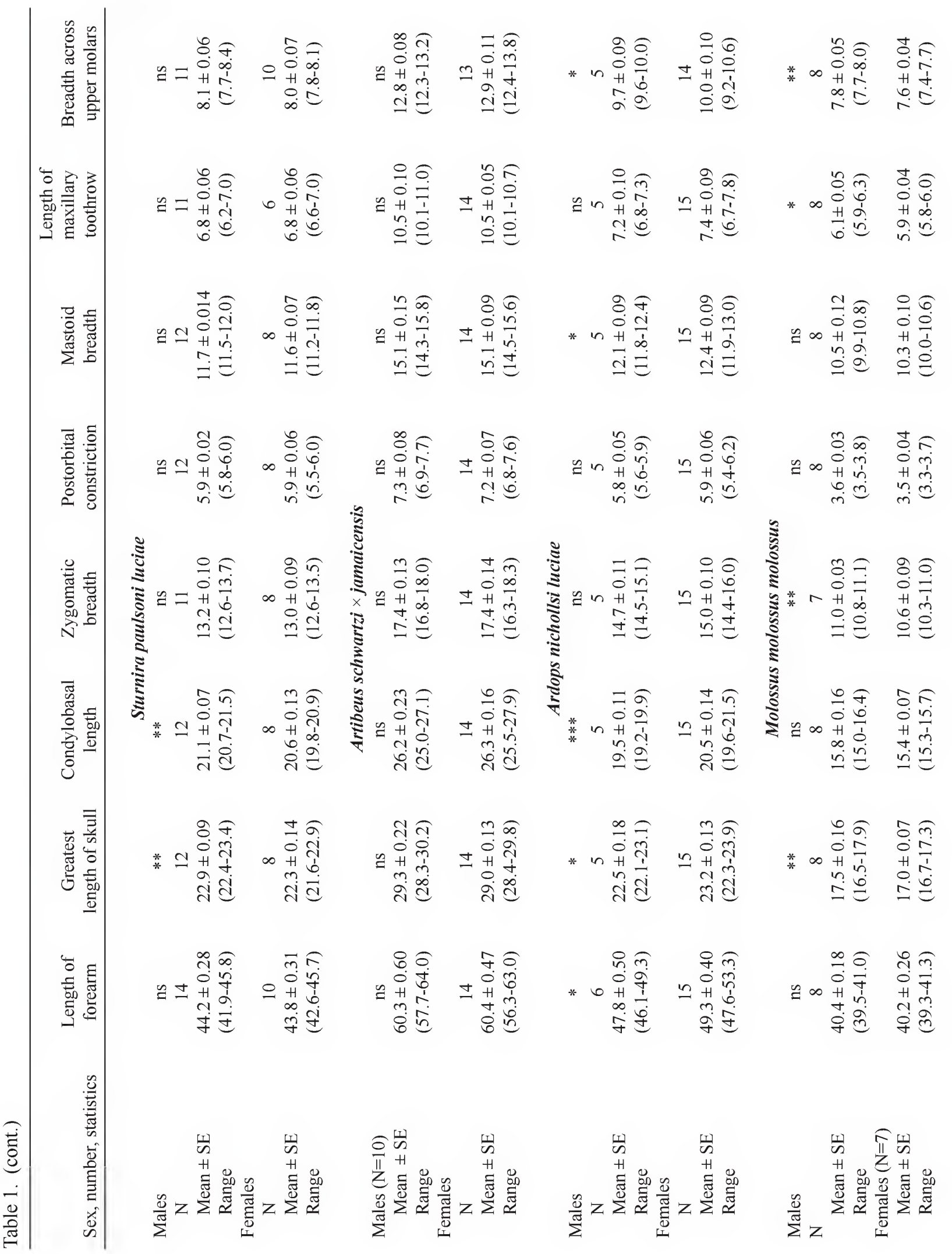




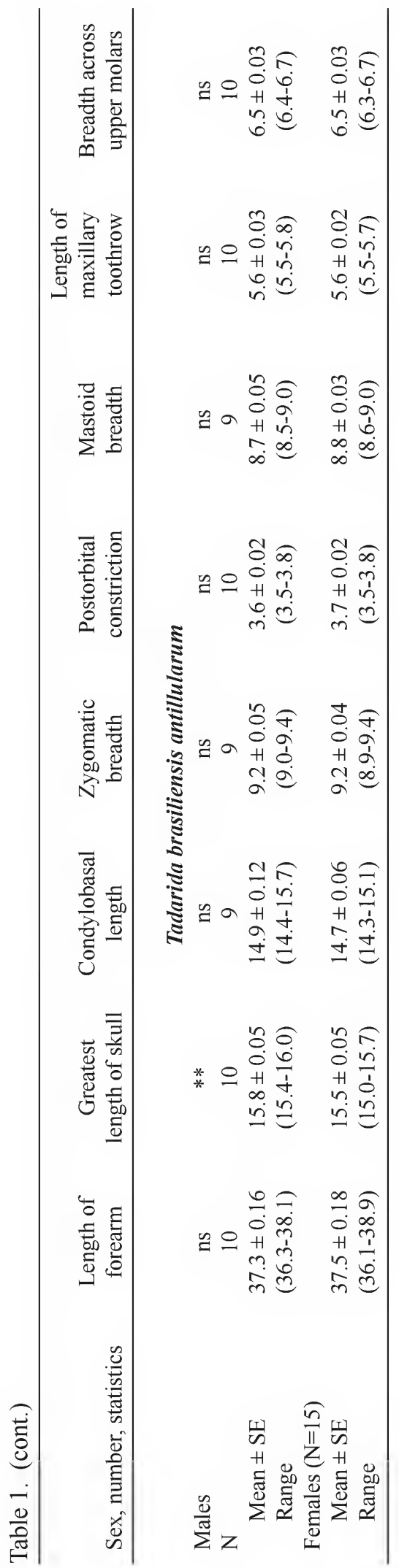

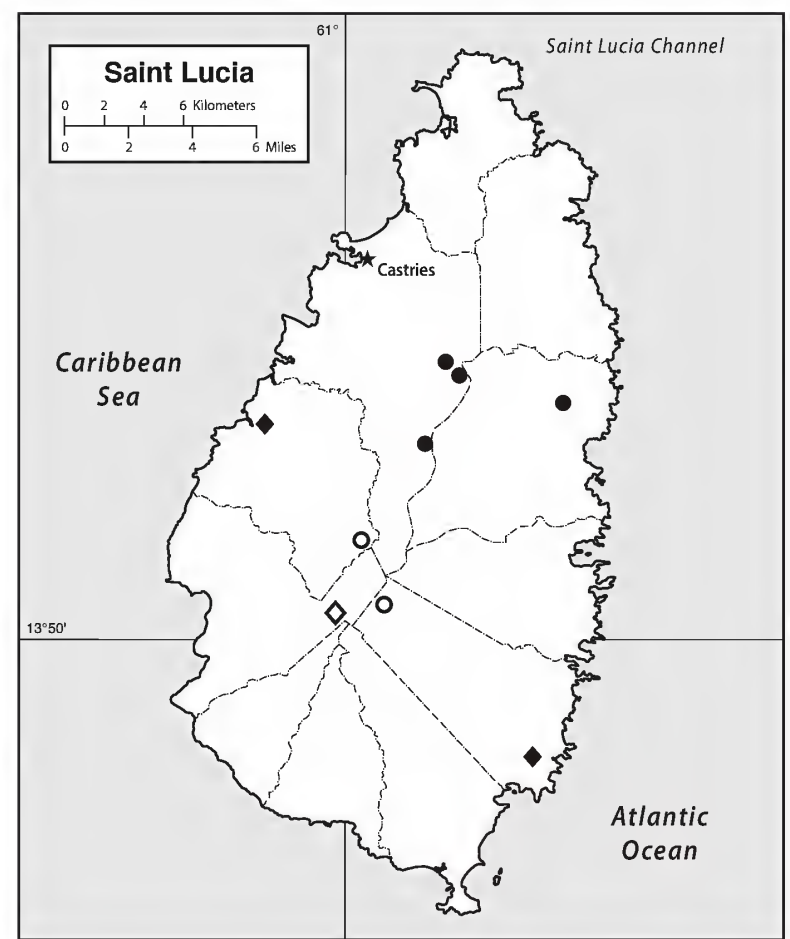

Figure 2. Map of the geographic distribution of Noctilio leporinus and Ardops nichollsi on the Lesser Antillean island of St. Lucia. Symbols represent: closed diamonds, specimens examined for Noctilio leporinus; open diamond, literature record of Noctilio leporinus; closed circles, specimens examined for Ardops nichollsi; open circles, literature records of Ardops nichollsi.

of the nets were placed at the east and west openings under the bridge to cover as much flight space under the bridge as possible. Beyond the bridge in both directions were concrete bridge abutments that were as high as $5 \mathrm{~m}$, and downstream from the bridge the river ran another $200 \mathrm{~m}$ before emptying into the harbor. Three Noctilio captured on this night were taken in these nets associated with the bridge. The third mist net was placed about $70 \mathrm{~m}$ upstream at the river's first fork. The fourth Noctilio of the evening was taken in this net. Eight Artibeus captured at this locality were taken in the same nets that caught the Noctilio.

Five mist nets were placed along the Canelles River upstream from the bridge where the river passed under the Micoud Highway. Two mist nets were placed across the river itself and three additional nets were used to bracket the gravel road adjacent to the river 


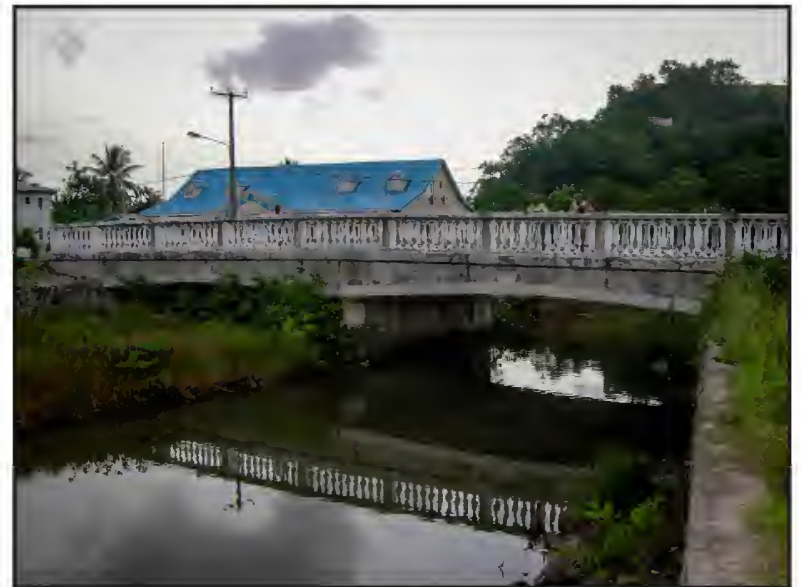

Figure 3. Photograph of Petite Rivière de l'Anse La Raye, Anse La Raye Quarter, St. Lucia. Three Noctilio leporinus were captured in mist nets set adjacent to this bridge.

where there were banana plants and scattered mango trees. Along the road and between the road and river was highly degraded dry scrub woodland, with shrubs and small trees. The riverbank was severely eroded with steep sides that made access to the river a challenge. A single Noctilio was captured in a $6 \mathrm{~m}$ mist net set across the river. Other species of bats caught along the road were A.jamaicensis $\times$ schwartzi, P. davyi, and M. molossus.

During the survey work by Clarke (2009) on St. Lucia, an adult female Noctilio was netted in wet forest at $550 \mathrm{~m}$ elevation at Edmund Forest Reserve. The bat was taken on a wide trail that lacked canopy cover. Numerous small streams flowed through the area, which was largely planted with blue mahoe and other non-native trees. This was an unusual record because the site was far from the coast and any large river or lakes.

Only one female Noctilio was taken during our work on St. Lucia. This individual was captured on the evening of 3 August 2008 and evinced no gross reproductive activity. Two adult males taken on this same night had testes lengths of 10 and 12, whereas both young adult males had testes lengths of 3 . Based on the summary of the reproductive cycle of this species by Hood and Jones (1984), August should be part of a period of reproductive inactivity for Noctilio.
This adult female weighed 51.7, whereas the two adult males weighed 65.0 and 65.8 and two young adult males weighed 52.5 and 53.8 .

Both color phases known in this species were collected on St. Lucia. The pelage of the female was an overall dark yellowish color, whereas three of the males exhibited russet venters.

\section{Family Mormoopidae \\ Pteronotus davyi davyi Gray, 1838 \\ Davy's Naked-backed Bat}

Specimens examined (21).-Castries: Barre de l'Isle Ridge, $0.5 \mathrm{~km} \mathrm{~S}, 1.3 \mathrm{~km}$ E Rivine Pois-

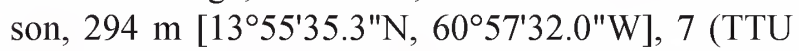
110296-99, 110305-07); Forestière Forest Trailhead, $0.5 \mathrm{~km} \mathrm{~S}, 0.5 \mathrm{~km}$ E Forestière, $300 \mathrm{~m}\left[13^{\circ} 58^{\prime} 11.2^{\prime \prime} \mathrm{N}\right.$, 6057'08.8"W], 1 (TTU 110295). Dennery: Au Leon Peak, $1 \mathrm{~km} \mathrm{~N}, 1.75 \mathrm{~km}$ E La Ressource, $319 \mathrm{~m}$ [135' 14.4"N, 6054'07.1"W], 5 (TTU 112640-44). Laborie: $1.25 \mathrm{~km} \mathrm{~N}, 0.75 \mathrm{~km}$ E Saltibus, $398 \mathrm{~m}$

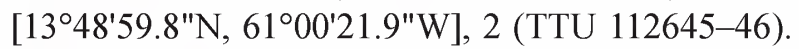
Micoud: Canelles River, $1.5 \mathrm{~km} \mathrm{~S}$ Anse Ger, $10 \mathrm{~m}$ [1346'59.6"N, 6054'53.1"W], 2 (TTU 110302-03); Forest Reserve, $2.5 \mathrm{~km} \mathrm{~N}, 8 \mathrm{~km} \mathrm{~W}$ Micoud, $283 \mathrm{~m}$ [1350'23.1"N, 6058'25.8"W], 2 (TTU 110300-01). Praslin: Raillon Negres, $1.2 \mathrm{~km} \mathrm{~N}, 2.3 \mathrm{~km} \mathrm{~W}$ Mon Repos, $255 \mathrm{~m}$ [135'ㄹ' 25.3"N, 6056'09.6"W], 1 (TTU 110304). Soufrière: Edmund Forest Reserve, $0.7 \mathrm{~km}$ $\mathrm{N}, 1.5 \mathrm{~km}$ E Fond St. Jacques, $550 \mathrm{~m}\left[13^{\circ} 50^{\prime} 27.9^{\prime \prime} \mathrm{N}\right.$, 6059'47.6"W], 1 (TTU 110308).

Additional records (Clarke 2009).-Anse La Raye: "Anse La Raye" [= Venus Estate] [converted from UTM, 135' $\left.14.7 " \mathrm{~N}, 61^{\circ} 01^{\prime} 12.1^{\prime \prime} \mathrm{W}\right]$. Castries: Barre de l'Isle Ridge, $0.5 \mathrm{~km} \mathrm{~S}, 1.3 \mathrm{~km}$ E Rivine Pois-

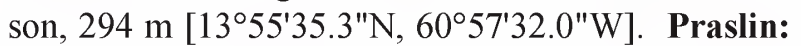
"Durocher" [= Morne Durocher] [converted from UTM, 1352'34.4"N, 6056'12.5"W].

Specimens captured/released (4).-Castries: Barre de l'Isle Ridge, $0.5 \mathrm{~km} \mathrm{~S}, 1.3 \mathrm{~km}$ E Rivine Poisson, 294 m [135' $\left.35.3^{\prime \prime} \mathrm{N}, 60^{\circ} 57^{\prime} 32.0^{\prime \prime} \mathrm{W}\right]$, 3. Laborie: $1.25 \mathrm{~km} \mathrm{~N}, 0.75 \mathrm{~km}$ E Saltibus, $398 \mathrm{~m}\left[13^{\circ} 48^{\prime} 59.8^{\prime \prime N}\right.$, 61ํำ'21.9"W], 1. 
Acoustic records.-Clarke (2009) recorded this species at four of his 16 field sites: Castries: Barre de l'Isle Ridge. Dauphin: Mount Gaiac. Praslin: Morne Durocher. Soufrière: Edmund forest.

In 2007, we collected Pteronotus davyi for the first time from St. Lucia (Fig. 4). This was not a surprise given that it is found on several islands in the region: Marie Galante (Masson et al. 1990; Timm and Genoways 2003), Dominica (Genoways et al. 2001), Martinique (Issartel and Lablanc 2004; Barataud et al. 2011), and Grenada (Genoways et al. 1998). However, our surveys failed to find this species on Barbados (Genoways et al. 2011), the Grenadines (Genoways et al. 2010), and St. Vincent (Kwiecinski et al. 2018). The congeneric Pteronotus fuscus was found immediately to the south on the island of St. Vincent where $P$. davyi has not been documented (Vaughan 1995; Vaughan and Hill 1996; sensu Kwiecinski et al. 2018).

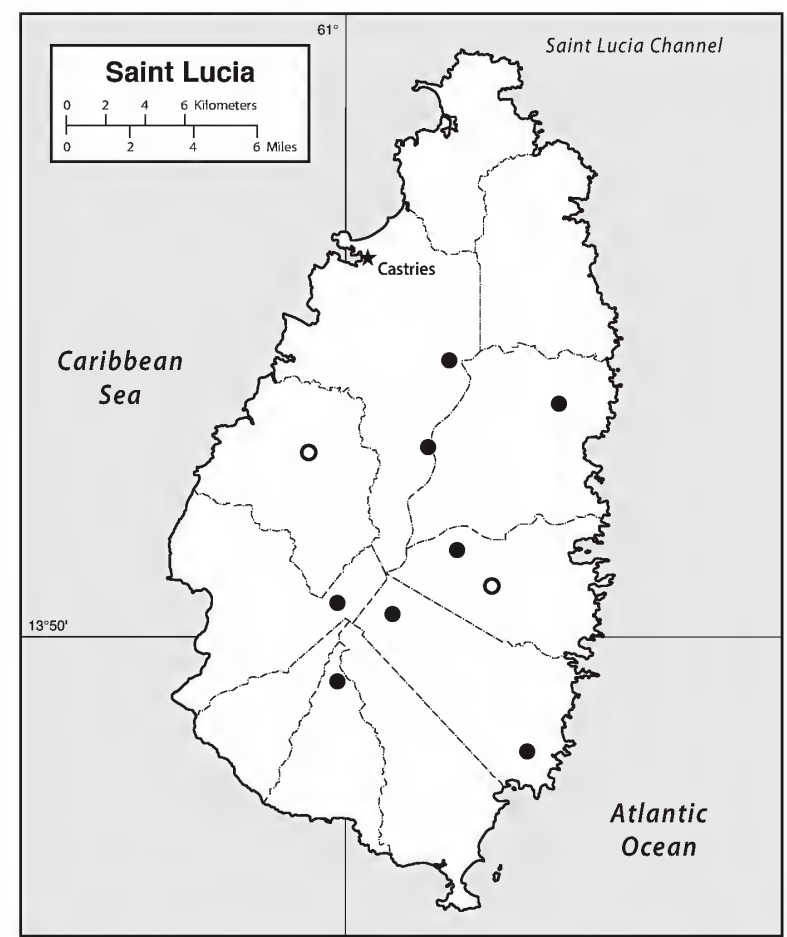

Figure 4. Map of the geographic distribution of Pteronotus davyi on the Lesser Antillean island of St. Lucia. Symbols include: closed circles represent specimens examined and open circles represent literature records.
Smith (1972) revised members of the family Mormoopidae. Although he noted some morphological differences among the populations, he assigned bats occurring in Nicaragua, Costa Rica, Venezuela, Trinidad, and on several of the Lesser Antilles to the nominate subspecies, $P$. d. davyi. Genoways et al. (2001) reported that individuals of this bat from the island of Dominica were significantly larger in greatest length of skull $(P \leq 0.01)$ and breadth of braincase $(P \leq 0.05)$ than a sample from Trinidad, which is the type locality for $P$. davyi. They also found that the sample from Trinidad was significantly larger than the material from Dominica in postorbital constriction $(P \leq 0.05)$. The inclusion of the St. Lucia material into this mix adds to the confusion. In length of forearm and five cranial measurements, the sample from St. Lucia averaged smaller than the samples from Dominica and Trinidad, whereas the sample from St. Lucia averaged the largest of the three populations for condylobasal length and postorbital constriction. Recently, Pavan and Marroig (2016) found that 14 individuals of $P$. davyi that we collected on St. Lucia were closely related to those on Trinidad and Dominica, that is, less than $1 \%$ sequence divergence in mitochondrial cytochrome- $b$ gene DNA sequence data. We thereby apply the name $P$. d. davyi to these island populations following both Smith (1972) and Pavan and Marroig (2016).

Table 1 presents length of forearm and seven cranial measurements for six male and six female Pteronotus from St. Lucia. Smith (1972) found little secondary sexual variation in any mormoopid. Our data support this finding with no significant difference being found between males and females in the eight measurements tested. Males averaged larger than females in two measurements (length of forearm and greatest length of skull) and females averaged larger in two measurements (postorbital constriction and mastoid breath), with the means for the four remaining measurements being the same for the sexes.

We netted at the Barre de l'Isle Ridge site on two occasions (19 June 2007 and 3 August 2008). This steep, narrow ridge extends from the northern highlands and rainforests of the central axis of mountains to the southern highlands with their rainforests and delineates the Atlantic from the Caribbean watersheds. At $294 \mathrm{~m}$, it is one of lower points along the divide, 
serving as a pass for the major east-west highway on the island. The ridge was covered with rainforest at its highest levels, which were flanked by well-developed lower montane rainforest, with trees reaching $30 \mathrm{~m}$ in height in some areas. Common trees of this forest type include candlewood, bois de masse, balata chien, bois cote, and palétuvier. We noted old tree stumps in the area, indicating at least some selective logging had occurred. In general, nets were set along the ridge top along an access road that led from a picnic area just south of the main highway then northward to the where the road dropped quickly down the eastern side of the ridge (Fig. 5). During our first visit to the site, we netted in fog. We captured the same six species of bats during both visits to the site. A total of 10 Pteronotus were obtained here, more than at any other place on the island. The other five species taken each year were the five species of fruit bats known from St. Lucia: $M$. plethodon (61), B. cavernarum (9), A. nichollsi (12), A. jamaicensis $\times$ schwartzi (129), and S. paulsoni (18).

The night of 16 March 2009, we worked along the top of a steep ridge that marked the northern limit of the Mabouya Valley. Au Leon Peak was one of the high points along this ridge. The ridge had been logged in the past and replaced with plantations of blue mahoe

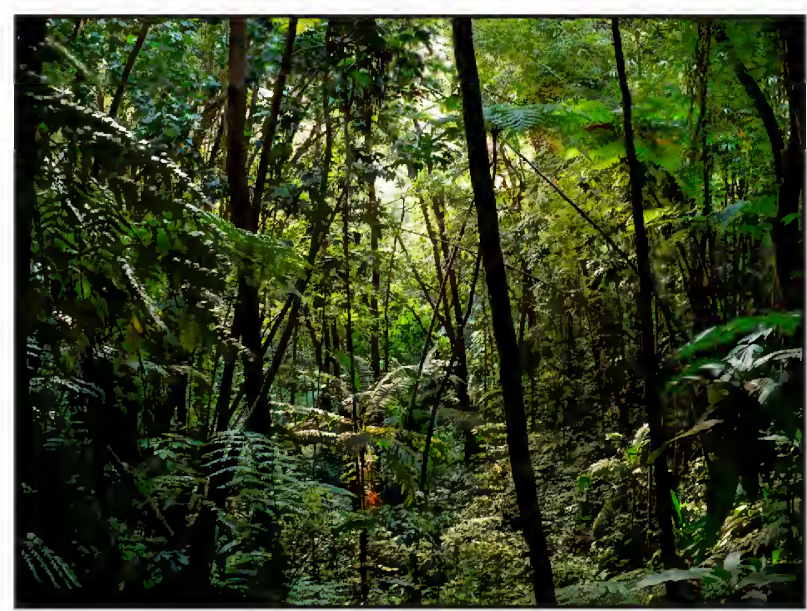

Figure 5. Photograph of the secondary tropical forest along Barre de l'Isle Ridge, Castries Quarter, St. Lucia. Ten Pteronotus davyi were captured along trails in this forest on two nights of mist netting. and Caribbean pine. The slopes in many places were relatively open with short $(1-1.5 \mathrm{~m})$ pioneer vegetation. We placed six nets along the access road and small paths that intersected the road. In some places, the high banks along the road formed a flyway for the bats. This was one of three places on the island that we caught seven species of bats in a single night. These included two insectivorous bats- $P$. davyi (5) and $M$. molossus (8) - and the five species of frugivores known from the island-M. plethodon (2), A. nichollsi (4), $B$. cavernarum (3), A. jamaicensis $\times$ schwartzi (18), and S. paulsoni (1).

Eight Pteronotus were captured on St. Lucia on 16 and 17 March 2009, of which four were pregnant females with embryos measuring $8,10,10$, and 14 , two were females evincing no gross reproductive activity, and two were scrotal males with testes measuring 3 in length. Clarke (2009) reported capturing one pregnant female on St. Lucia on 6 April. Only four males were obtained during our netting efforts between 17 and 20 June 2007, with three being scrotal males with testes of 3 in length and one male with testes in an inguinal position measuring 2 in length. Of six females captured on St. Lucia during our field studies 1 to 4 August 2008, four were lactating and two evinced no reproductive activity. Four males netted between 31 July and 4 August had testes in a non-scrotal position and had testes lengths of $1,2,3$, and 4 . The reproductive data from our study matches the seasonal monoestry cycle found in previous studies for this species (Wilson 1973; Adams 1989). Breeding occurs in January and February, with gestation through the spring dry season. Births were timed for the onset of the rainy season in May and June, with lactation occurring through July into early August. Near full-term embryos had a crown-rump length of 25 (Adams 1989).

Weights of Pteronotus recorded from St. Lucia were as follows: mid-March—pregnant females, 7.2, 7.4, 7.4, 7.5; non-reproductive females, 7.1, 7.4; scrotal males, 6.8, 6.9; mid-June-scrotal males, 7.7, 8.1, 9.1; non-scrotal male, 8.1 ; late July-early August - lactating females, 7.5, 7.8, 7.8, 7.9; non-reproductive females, 7.6, 7.6; non-scrotal males, 7.1, 7.5, 7.6, 8.9. 


\section{Family Phyllostomidae \\ Monophyllus plethodon plethodon Miller, 1900 Insular Single-leaf Bat}

Specimens examined (46).-Castries: Barre de l'Isle Ridge, $0.5 \mathrm{~km} \mathrm{~S}, 1.3 \mathrm{~km}$ E Rivine Poisson, 294 m [13ㄷ5'35.3"N, 6057'32.0"W], 2 (TTU 110009-10); Forestière Forest Trailhead, $0.5 \mathrm{~km} \mathrm{~S}, 0.5 \mathrm{~km}$ E For-

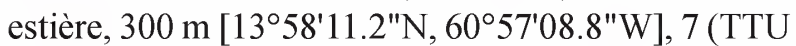
109988-109994); Marigot Bay, 1 (UNSM 16568); Piton Flore, Forestière Forest Trail, $1.2 \mathrm{~km} \mathrm{~S}, 1.9 \mathrm{~km}$ E Forestière, $300 \mathrm{~m}\left[13^{\circ} 57^{\prime} 51.6^{\prime \prime} \mathrm{N}, 60^{\circ} 56^{\prime} 24.0^{\prime \prime} \mathrm{W}\right]$, 1 (TTU 109995). Dennery: Au Leon Peak, 1 km $\mathrm{N}, 1.75 \mathrm{~km}$ E La Ressource, $319 \mathrm{~m}$ [135' $57^{\prime} 14.4^{\prime \prime} \mathrm{N}$, 6054'07.1"W], 2 (TTU 111488-89). Laborie: 1.25

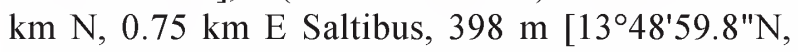
6100'21.9"W], 5 (TTU 111490-94). Micoud: Quilesse Forest Reserve, $2.5 \mathrm{~km} \mathrm{~N}, 8 \mathrm{~km}$ W Micoud, 283 m [1350'23.1"N, 6058'25.8"W], 7 (TTU 109997110003); Troumassee River, $1.3 \mathrm{~km} \mathrm{~W}$ Micoud, 40 m [134''13.9"N, 6054'53.7"W], 1 (TTU 109996). Praslin: Fox Grove Inn, $1.1 \mathrm{~km} \mathrm{~N}, 0.2 \mathrm{~km}$ W Mon Repos, $52 \mathrm{~m}\left[13^{\circ} 51^{\prime} 47.0^{\prime \prime N}, 60^{\circ} 54^{\prime} 22.8^{\prime \prime} \mathrm{W}\right], 1$ (TTU 110004); Raillon Negres, $1.2 \mathrm{~km} \mathrm{~N}, 2.3 \mathrm{~km} \mathrm{~W}$ Mon

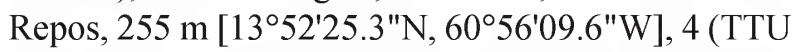
110005-08). Vieux Fort: Woodland Estate, $2.25 \mathrm{~km} \mathrm{~N}$, $1.3 \mathrm{~km} \mathrm{~W}$ Grace, $211 \mathrm{~m}\left[13^{\circ} 47^{\prime} 54.7^{\prime \prime} \mathrm{N}, 60^{\circ} 58^{\prime} 50.7^{\prime \prime} \mathrm{W}\right]$, 2 (TTU 110011-12). No Specific Quarter: no specific locality, 13 (NMNH 106090-94, 110901-05).

Additional records (Clarke 2009, unless otherwise noted).-Anse La Raye: Millet Forest [= Millet Bird Sanctuary] [converted from UTM, 13 $53^{\circ} 44.7^{\prime \prime} \mathrm{N}$, $60^{\circ} 59^{\prime} 50.2^{\prime \prime} \mathrm{W}$. Castries: Barre de l'Isle Ridge, 0.5 $\mathrm{km} \mathrm{S}, 1.3 \mathrm{~km}$ E Rivine Poisson, $294 \mathrm{~m}$ [converted from UTM, $\left.13^{\circ} 55^{\prime} 35.3^{\prime \prime} \mathrm{N}, 60^{\circ} 57^{\prime} 32.0^{\prime \prime} \mathrm{W}\right]$. Praslin: "Durocher" [= Morne Durocher] [converted from UTM, 1352'34.4"N, 6056'12.5"W]. No Specific Quarter: no specific locality (Miller 1902; Schwartz and Jones 1967).

Specimens captured/released (127).-Castries: Barre de l'Isle Ridge, $0.5 \mathrm{~km} \mathrm{~S}, 1.3 \mathrm{~km}$ E Rivine

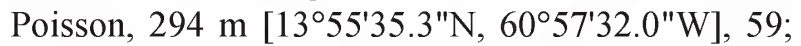
Forestière Forest Trailhead, $0.5 \mathrm{~km} \mathrm{~S}, 0.5 \mathrm{~km} \mathrm{E}$ Forestière, $300 \mathrm{~m}\left[13^{\circ} 58^{\prime} 11.2^{\prime \prime} \mathrm{N}, 60^{\circ} 57^{\prime} 08.8^{\prime \prime} \mathrm{W}\right]$, 3. Dennery: Dennery River, $0.25 \mathrm{~km} \mathrm{~S}, 2 \mathrm{~km} \mathrm{~W}$ Dennery, $11 \mathrm{~m}\left[13^{\circ} 54^{\prime} 34.6^{\prime \prime} \mathrm{N}, 60^{\circ} 54^{\prime} 16.2^{\prime \prime} \mathrm{W}\right], 1$.
Laborie: $1.25 \mathrm{~km} \mathrm{~N}, 0.75 \mathrm{~km}$ E Saltibus, $398 \mathrm{~m}$

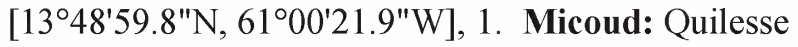
Forest Reserve, $2.5 \mathrm{~km} \mathrm{~N}, 8 \mathrm{~km} \mathrm{~W}$ Micoud, $283 \mathrm{~m}$ [13 50 '23.1"N, 6058'25.8"W], 52. Praslin: Raillon Negres, $1.2 \mathrm{~km} \mathrm{~N}, 2.3 \mathrm{~km}$ W Mon Repos, $255 \mathrm{~m}$ [13 $\left.3^{\circ} 52^{\prime} 25.3^{\prime \prime} \mathrm{N}, 60^{\circ} 56^{\prime} 09.6^{\prime \prime} \mathrm{W}\right]$, 3. Soufrière: Edmund Forest Reserve, $0.7 \mathrm{~km} \mathrm{~N}, 1.5 \mathrm{~km}$ E Fond St. Jacques, $550 \mathrm{~m}\left[13^{\circ} 50^{\prime} 27.9^{\prime \prime} \mathrm{N}, 60^{\circ} 59^{\prime} 47.6^{\prime \prime} \mathrm{W}\right]$, 6. Vieux Fort: Woodland Estate, $2.25 \mathrm{~km} \mathrm{~N}, 1.3 \mathrm{~km} \mathrm{~W}$ Grace, $211 \mathrm{~m}$ [13ํำ $\left.54.7^{\prime \prime} \mathrm{N}, 60^{\circ} 58^{\prime} 50.7^{\prime \prime} \mathrm{W}\right], 2$.

Miller (1902) originally described the Monophyllus on St. Lucia under the name Monophyllus luciae, based on 13 specimens collected by H. S. Branch in 1901 from two unspecified sites, one of which was in the Laborie Quarter. Schwartz and Jones (1967) revised $M$. plethodon, recognizing two extant subspecies, $M$. p. plethodon and M. p. luciae. Schwartz and Jones (1967) restricted the nominate subspecies to Barbados, whereas populations of M. plethodon from throughout the remainder of the Lesser Antilles, from Anguilla southward to St. Vincent, were assigned to M. p. luciae. A fossil from Puerto Rico was recognized under the name M. p. frater. When Schwartz and Jones (1967) studied M. plethodon, they stated: "It is purely on the basis of the holotype that we recognize M. p. plethodon as distinct from other Lesser Antillean populations." The holotype of M. p. plethodon was smaller than other specimens of M. plethodon, including the second specimen from Barbados. Schwartz and Jones (1967) were uncertain about their decision in recognizing both $M . p$. plethodon and M. p. luciae and opined that additional material from these islands could alter their decision. A genetic analysis of St. Lucian M. plethodon remains to be conducted.

With adequate samples available from both Barbados and St. Lucia, Genoways et al. (2011) examined the morphological variation between these populations. Surprisingly, the males from St. Lucia were significantly different from those on Barbados in five of seven measurements, whereas the females were significantly different in only two measurements and, in fact, females from these two islands averaged the same in four measurements. The males from St. Lucia were significantly smaller than those from Barbados in four (greatest length of skull, zygomatic breadth, postorbital constriction, and mastoid breadth) 
of the five measurements. Males from St. Lucia were significantly larger than those from Barbados in length of the maxillary toothrow. The females from St. Lucia were significantly larger than those from Barbados in two measurements - length of forearm and length of the maxillary toothrow. Based on these results, Genoways et al. (2011) concluded that M. plethodon from Barbados were not smaller than those on St. Lucia as supposed by Schwartz and Jones (1967). Recently, Kwiecinski et al. (2018) studying material from St. Vincent found that it further clouded the relationship between these subspecies. They found a tendency for the St. Vincent material to group with the St. Lucia material in some measurements, but the St. Vincent material was intermediate between the values from the other two islands. They concluded that there was "no continuing need to recognize the taxon Monophyllus plethodon luciae Miller 1902 and it should be placed as a junior synonym of Monophyllus plethodon plethodon Miller 1900." This is the taxonomic arrangement followed here.

On St. Lucia, there were no significant differences in length of forearm and seven cranial measurements between fourteen males and fourteen females (Table 1). The averages for length of forearm and maxillary toothrow were the same for both sexes, averages for greatest length of skull, condylobasal length, and postorbital constriction were larger in females than males, and zygomatic breadth, mastoid breath, and breadth across molars were greater in males than females.

During our study, this species represented $9.4 \%$ of all bat captures on St. Lucia and was captured from near sea level on the Dennery River $(11 \mathrm{~m})$ to our highest elevation sampled in the Edmund Forest Reserve (550 $\mathrm{m})$. The species was found in essentially all vegetation types unless the area was too highly disturbed (Fig. 6). We caught the greatest number of these bats (59 individuals in 11 nets) at the 14,000-ha Quilesse Forest Reserve (Fig. 7) that was situated above the Roseau River drainage. This interior plateau was covered in lower montane rain forest and drier deciduous forest where we found considerable amounts of fruit on the ground. In 2008, we placed 11 mist nets at this site with five placed along a trail above the Forestry Station and six placed across the entrance road and down a road leading to the nearby stream. A total of 294 bats were captured that evening (26.7 BNN), 59 of which were Monophyllus ( $20 \%$ of all captures at the site). The other species of bats taken at the site included: $A$. jamaicensis $\times$ schwartzi (212), S. paulsoni (18), P. davyi (2), M. molossus (2), and B. cavernarum (1).

The Forestière Forest Trailhead was at the edge of the Castries Waterworks Forest Reserve, which was established in 1916 (Beard 1949). The vegetation at this netting site was a mix of primary rainforest and lower montane rainforest, with such trees as candlewood, bois de masse, balata chien, and bois cote. We set six nets - two were set along trails into the forest and an $18 \mathrm{~m}$ long net was placed at the edge of the parking lot along the forest edge. The other three nets were placed in a banana plantation situated just outside of the Reserve. This was one of three netting sites where we captured seven species of bats-the highest number of species from our survey sites on St. Lucia. In addition to 10 Monophyllus, we netted six other species here:

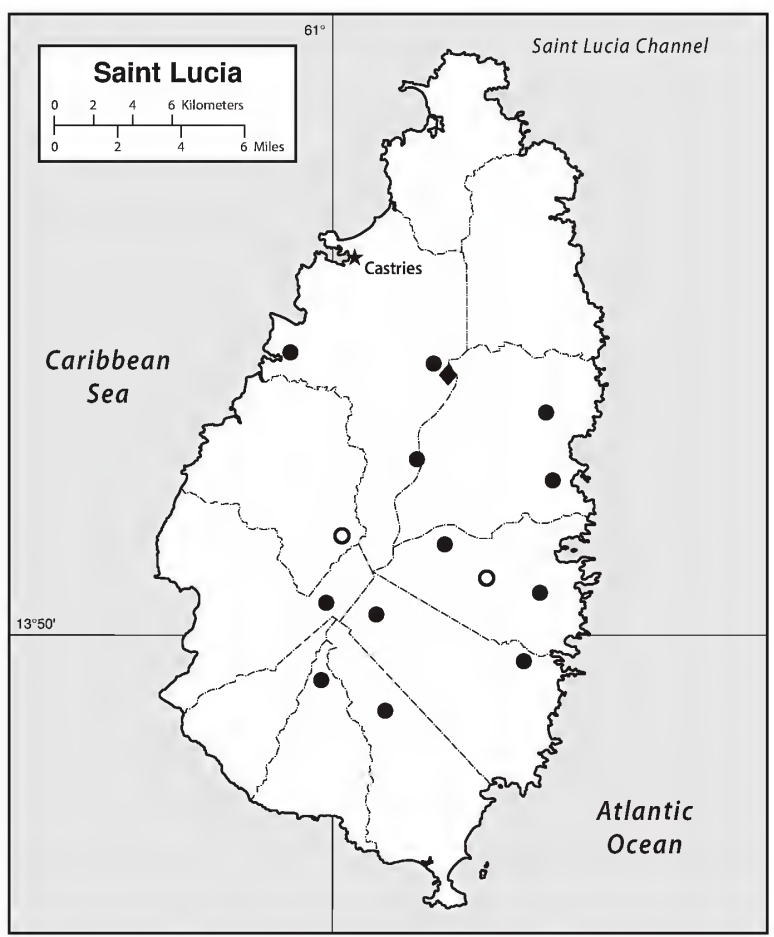

Figure 6. Map of the geographic distribution of Monophyllus plethodon on the Lesser Antillean island of St. Lucia. Symbols include: closed circles represent specimens examined and open circles represent literature records. 


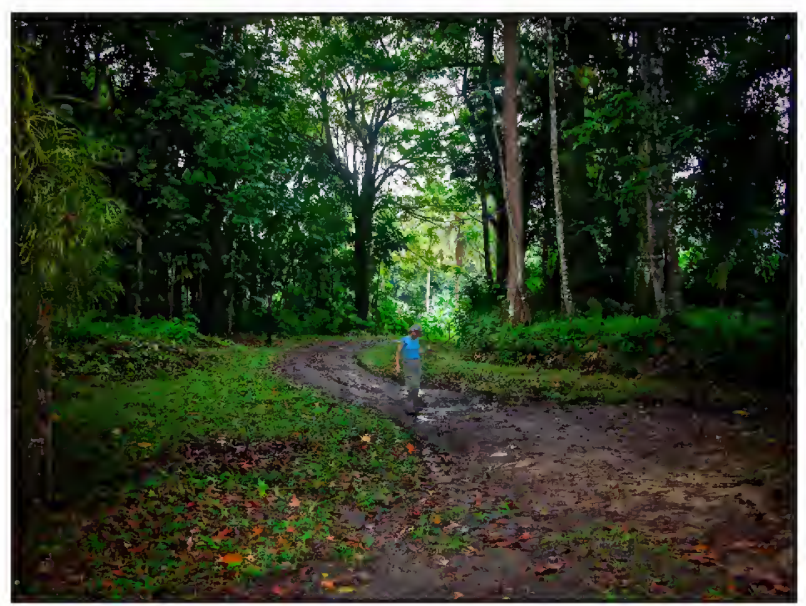

Figure 7. Photograph of the Quilesse Forest Reserve, Micoud Quarter, St. Lucia, showing the lower montane rain forest. We captured 59 Monophyllus plethodon in 11 mist nets in a single evening in this area.

P. davyi (1; this was the first specimen of the species obtained on St. Lucia), B. cavernarum (2), A. nichollsi (5), A. jamaicensis $\times$ schwartzi (66), S. paulsoni (1), and M. molossus (1).

Clarke (2009) reported that "at Durocher, a mesic forest site bordered by fruit plantations, mist nets intercepted a huge flock of these long-tongued bats and in less than three hours, 128 individuals were captured." It was our opinion that this was probably not a huge "flock" of bats but rather that his mist nets were set along a flyway between a colony of these bats and their foraging areas in the fruit plantations below.

On 4 February 1901, H. S. Branch collected 13 Monophyllus on St. Lucia, of which two were males and 11 were females. Both scrotal males had testes measuring 5. All females were pregnant carrying single embryos that averaged 15.2 (13-18) in crownrump length. On 16 and 17 March 2009, two females were collected that were carrying single embryos that measured 13 and 17 in crown-rump length. Six scrotal males were taken on these dates, five of the individuals having testes lengths of 3, 3, 3, 4, and 4. Clarke (2009) reported two palpably pregnant females were captured on 26 March and one pregnant female was captured on 1 April. Forty-eight Monophyllus were captured and examined during our survey between 17 and 20 June
2007, with 39 females and nine males constituting the sample. The reproductive status of the females was as follows: 5 pregnant; 8 lactating; 1 post-lactating; and 25 evinced no gross reproductive activity. One of the pregnant females was carrying an embryo that measured 21 in crown-rump length. Five of the males were scrotal and the other four had testes in an inguinal position. The scrotal males had testes lengths of $3,4,4$, 4 , and 4 and one of the non-scrotal males had a testes length of 2 . We examined 101 Monophyllus between 30 July and 4 August 2008, with 55 females and 46 males constituting the sample. The reproductive status of the females was as follows: 1 pregnant; 26 lactating; 4 post-lactating; 23 evincing no gross reproductive activity; and 1 subadult. Eight of the males had testes in a scrotal position and the other 38 had testes in an inguinal position. One of the scrotal males had a testes length of 3 and four of the non-scrotal males had testes lengths of $1,3,3$, and 3 .

Limited data indicate that Monophyllus might be monoestrous on St. Vincent (Kwiecinski et al. 2018). On Barbados, Genoways et al. (2011) did not have sufficient data to understand the entire reproductive cycle, but their data suggested a bimodal polyestrous cycle, or alternatively, populations belonging to different maternity colonies may not be synchronous in their reproductive cycles and young were produced over an expanded monoestrous cycle. On Dominica, Genoways et al. (2001) found that nine of 10 females were pregnant during the period of late March to late April, the embryos of which were near-term. Elements of these reproductive patterns were similar to what we have observed on St. Lucia-breeding occurred during the dry season in December and January with gestation taking place in February, March, and April. Parturition occurred in late April through early June as the wet season was beginning. Young bats started to fly as the wet season was reaching its height in July and August. However, five pregnant females captured in mid-June ( $13 \%$ of the females examined) and a pregnant female netted 1 August argue for a second wave of reproduction. It was unclear if the females had a postpartum estrus in March and April or if there was less synchronicity in breeding in Monophyllus than in many other phyllostomid bats in the region. Certainly, if there was a postpartum estrus, only a few females were participating. It appears that less than $10 \%$ of 
the females were pregnant during times when a second birth for the year would be expected. Additional records of this species through the months of July to September would be necessary to answer questions about its reproductive cycle.

Two pregnant females netted in mid-March weighed 13.2 and 14.5 , whereas six scrotal males from this time had a mean weight of 15.1 (13.7-15.9). Those Monophyllus taken on St. Lucia in mid-June had the following weights: five adult females revealing no gross reproductive activity, 13.2 (11.8-14.4); a pregnant female, 16.5; two lactating females, 12.9, 13.4; a post-lactating female, 13.2; five scrotal males, 14.7 (13.8-15.3); two non-scrotal males, 14.0, 14.7. Monophyllus taken on St. Lucia at the end of July and early August had the following weights: three adult females revealing no gross reproductive activity, 12.1, 13.4, 14.3; four lactating females, 12.3, 12.4, 13.7, 14.3; two post-lactating females, 12.7, 14.4; a scrotal male, 14.4; five non-scrotal males, 14.0 (12.6-15.2). Although our weight data were not extensive, males were heavier than females, on average.

\section{Brachyphylla cavernarum cavernarum Gray, 1834 Antillean Fruit-eating Bat}

Specimens examined (91).-Castries: Barre de l'Isle Ridge, $0.5 \mathrm{~km} \mathrm{~S}, 1.3 \mathrm{~km}$ E Rivine Poisson, 294

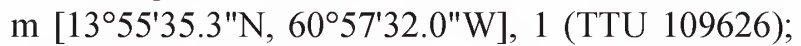
Forestière Forest Trailhead, $0.5 \mathrm{~km} \mathrm{~S}, 0.5 \mathrm{~km}$ E For-

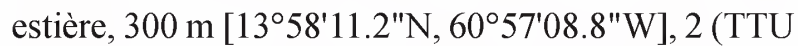
109624-25); 1.5 km E Marigot Bay, 4 (UNSM 16489 , 16563-65); Marigot Bay, 2 (UNSM 16569-70). Dau-

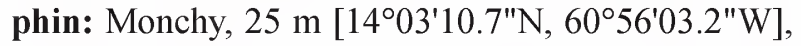
1 (TTU 111043). Dennery: Au Leon Peak, 1 km $\mathrm{N}, 1.75 \mathrm{~km}$ E La Ressource, $319 \mathrm{~m}\left[13^{\circ} 57^{\prime} 14.4^{\prime \prime} \mathrm{N}\right.$, 605'07.1"W], 3 (TTU 111044-46). Laborie: 1.25 $\mathrm{km} \mathrm{N}, 0.75 \mathrm{~km}$ E Saltibus, $398 \mathrm{~m}\left[13^{\circ} 48^{\prime} 59.8^{\prime \prime N}\right.$, $\left.61^{\circ} 00 ' 21.9^{\prime \prime} \mathrm{W}\right], 1$ (TTU 111047). Micoud: Quilesse Forest Reserve, $2.5 \mathrm{~km} \mathrm{~N}, 8 \mathrm{~km}$ W Micoud, $283 \mathrm{~m}$ [1350'23.1"N, 6058'25.8"W], 1 (TTU 109627). Soufrière: Diamond Botanical Garden, Diamond, 47

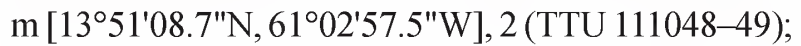
Edmund Forest Reserve, $0.7 \mathrm{~km} \mathrm{~N}, 1.5 \mathrm{~km}$ E Fond St. Jacques, $550 \mathrm{~m}\left[13^{\circ} 50^{\prime} 27.9^{\prime \prime} \mathrm{N}, 60^{\circ} 59^{\prime} 47.6^{\prime \prime} \mathrm{W}\right]$, 8 (TTU 109630-37); Soufrière Cave, Soufrière, $0 \mathrm{~m}$

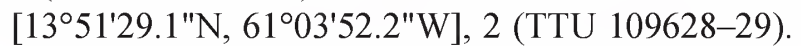

Vieux Fort: Grace Cave, 2.4 km N, 1 km W Grace, 165 $\mathrm{m}$ [134ㄱ'57.0"N, 6058'43.6"W], 8 (TTU 109638-45). No Specific Quarter: no specific locality, 56 (NMNH 106000-055).

Additional records.-Castries: Castries Waterworks Reserve, near Forestière $\left[\approx 13^{\circ} 58^{\prime} 13.3^{\prime \prime N}\right.$, $60^{\circ} 56^{\prime} 56.6 \mathrm{WW}$ (Arendt and Anthony 1986). No Specific Quarter: no specific locality (Miller 1913a; Koopman 1968; Swanepoel and Genoways 1978).

Specimens captured/released (9).-Castries: Barre de l'Isle Ridge, $0.5 \mathrm{~km} \mathrm{~S}, 1.3 \mathrm{~km}$ E Rivine Poisson, $294 \mathrm{~m}$ [13 $\left.55^{\circ} 35.3^{\prime \prime} \mathrm{N}, 60^{\circ} 57^{\prime} 32.0^{\prime \prime} \mathrm{W}\right]$, 8. Laborie: $1.25 \mathrm{~km} \mathrm{~N}, 0.75 \mathrm{~km}$ E Saltibus, $398 \mathrm{~m}\left[13^{\circ} 48^{\prime} 59.8^{\prime \prime} \mathrm{N}\right.$, $\left.61^{\circ} 00^{\prime} 21.9^{\prime \prime} \mathrm{W}\right], 1$.

The genus Brachyphylla is endemic to the Antilles and includes two species (Swanepoel and Genoways 1978). The northern species is B. nana, which occurs on Cuba, Grand Cayman, Middle Caicos, and Hispaniola. The larger of the two species, B. cavernarum, is known from Puerto Rico, the Virgin Islands, and the Lesser Antillean islands as far south as St. Vincent and Barbados. The members of the nominate subspecies occur on St. Croix in the Virgin Islands and throughout the Lesser Antillean islands south to St. Lucia and St. Vincent. The smaller subspecies, B. c. minor, occurs on Barbados (Genoways et al. 2011). A third subspecies, B. c. intermedia, was found on Puerto Rico and all Virgin Islands except St. Croix (Swanepoel and Genoways 1978). Although genetic analysis of St. Lucian B. cavernarum remains to be conducted, Carstens et al. (2004) reported a lack of mitochondrial DNA genetic variation in northern Lesser Antillean populations.

In the analysis of 12 cranial measurements presented by Swanepoel and Genoways (1978), the mean values of the St. Lucia population of Brachyphylla nearly matched those from the type locality of St. Vincent, except for palatal length of females, where the differential between the mean values of these two populations was $0.3 \mathrm{~mm}$ or less. The length of forearm and seven cranial measurements for fifteen males and fourteen females (Table 1) revealed no significant secondary sexual dimorphism. Average male measurements were larger for greatest length of skull, condylobasal length, postorbital constriction, and mastoid breadth, whereas 
average female measurements were larger for length of forearm, zygomatic breadth, and breadth across upper molars. There was no difference between male and female averages for length of maxillary toothrow. Swanepoel and Genoways (1978) found males to be generally larger than females and concluded that there was sufficient secondary sexual dimorphism to analyze the sexes separately. This conclusion was not supported by our data. However, there is significant secondary sexual dimorphism in the structure of the pelvis, to the extent that this character was utilized to establish sex-ratios and determine periodic utilization of a cave roost by this species at a fossil maternity colony on the island of Marie Galante (Pelletier et al. 2017).

Ten of our 44 captures of this bat were from within two caves: Soufrière Cave (2) at sea level and Grace Cave (8) at $165 \mathrm{~m}$. The remaining 34 individuals were netted in a variety of foraging areas from $25 \mathrm{~m}$ to $550 \mathrm{~m}$ (Fig. 8). Several of these are profiled below. The amount of insect remains found in the feces of this omnivorous bat increase substantially during the early dry season (December-January) on the island of Guadeloupe (Lenoble et al. 2014a).

Grace Cave (Fig. 9) served as a day roost for a colony of Brachyphylla. Reaching the cave required a descent of approximately $50 \mathrm{~m}$ down a very steep ravine from an unpaved road at the ridge top. The cave was located below a small waterfall on the rockstrewn ravine floor. The small stream running adjacent to the cave was thought to be a tributary of the Grande Rivière du Vieux Fort. Grace Cave was a solution cave approximately $15 \mathrm{~m}$ deep into the ravine wall and about $30 \mathrm{~m}$ wide along the stream. The dome of the ceiling varied from 3 to $5 \mathrm{~m}$ high above a mostly dry cobble floor. Because the colony was disturbed by our entry in the cave, we were unable to determine the size of the colony, but only Brachyphylla was observed in this roost.

We located a second day roost for Brachyphylla on St. Lucia in a sea cave located on the north side of the Soufrière Bay. This cave consisted of a tapering vertical fissure that was 3 to $4 \mathrm{~m}$ wide at its base and extended $14 \mathrm{~m}$ upwards. At the time Clarke visited (March 2009) "this roost consisted of several thousand, noisy, squabbling Antillean fruit bats, visually esti-

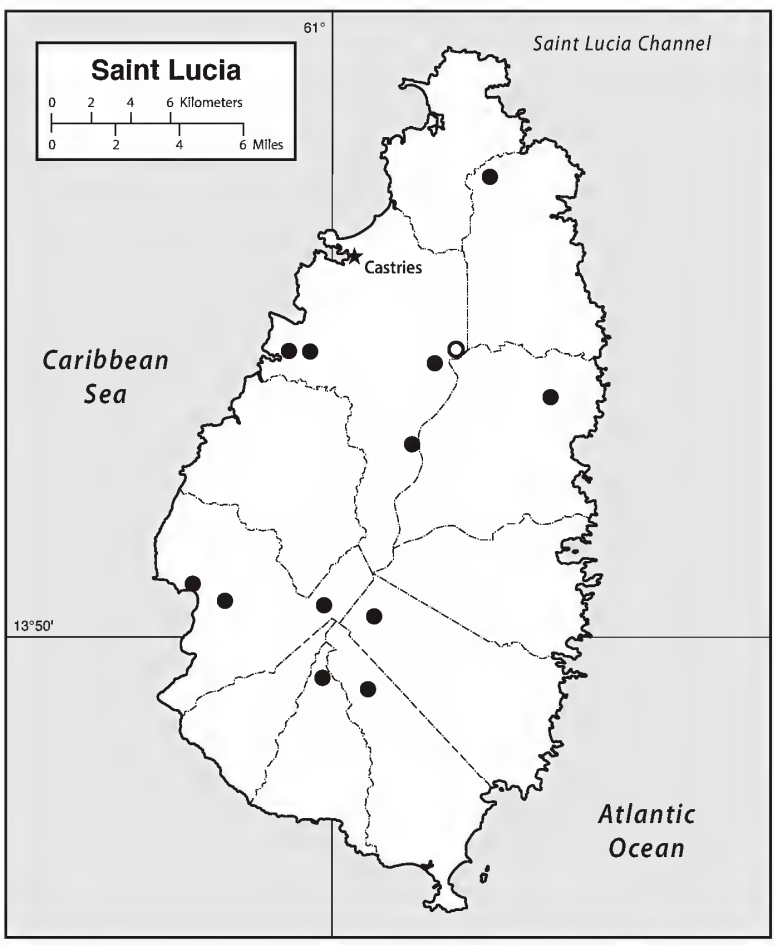

Figure 8. Map of the geographic distribution of Brachyphylla cavernarum on the Lesser Antillean island of St. Lucia. Symbols include: closed circles represent specimens examined and the open circle represents a literature record.

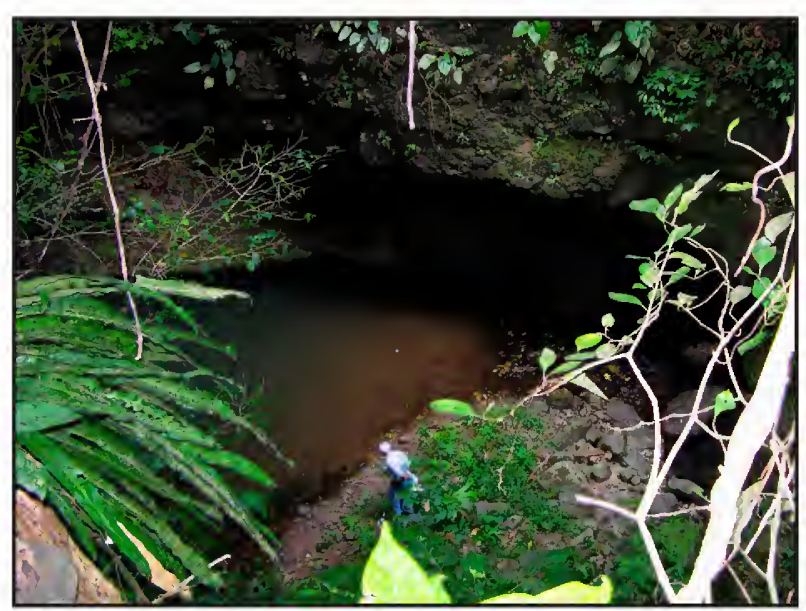

Figure 9. Photograph of the mouth of Grace Cave, Viex Fort Quarter, St. Lucia, taken from above on the bank of the small stream. The cave was occupied by a colony of Brachyphylla cavernarum. 
mated at $\sim 5,000$ individuals, but no other bats species were observed" (Clarke 2009).

In the Castries Waterworks Reserve, Arendt and Anthony (1986) located a colony of Brachyphylla in a large cavity within an acomat boucan tree. They reported: "Trunk circumference at breast height was 2.82 $\mathrm{m}$. Vertical distance to the cavity was $7.22 \mathrm{~m}$. Cavity height, width, and inside diameter were $2.74,0.24$, and $0.50 \mathrm{~m}$, respectively." They observed a juvenile St. Lucia boa (Boa constrictor orophias) feeding on the bats in the colony. A pregnant female bat weighing 67 $\mathrm{g}$ and a length of forearm of 63.1 was extracted from the mouth of the snake.

A sample of Brachyphylla was obtained during the period of 4 January to 10 February 1901 that included 15 females of which 14 were pregnant and one showed no gross reproductive activity. The 14 embryos carried by these females were relatively small, with an average crown-rump length of 8.4 (5-12). Two scrotal males taken during this time had testes measuring 6 and 8 in length, whereas 18 males had testes in an inguinal position and seven of those had testes lengths that averaged 4.6 (3-6). Two females captured on 4 March 1901 each carried a single embryo that measured 6 and 16 in crown-rump length. In mid-March (14-17), at the depth of the dry season, all seven females captured were pregnant, with six of the embryos having a mean crown-rump measurement of 21 (18-24). A scrotal male captured during this period had testes measuring 6 in length. Arendt and Anthony (1986) reported a pregnant female taken on 20 March 1984 , but they give no indication of the size of the fetus. By the onset of the rainy season in mid-June (17-20), all nine of the adult females captured were lactating. Nine adult males captured during this time were all judged to reproductively inactive, with testes in a non-scrotal position and measuring an average of 5 (3-6) in length. As the rainy season was approaching its height, eight adult females were captured one of which was lactating and the other seven evinced no gross reproductive activity. The one scrotal male taken had a testes length of 7 , whereas three males with testes in an inguinal position had lengths of testes of 4 , 4 , and 6 . The female reproductive cycle begins with breeding early in the dry season (December-January) and Krutzch and Nellis (2006) found spermatogenesis in males from September to December on St. Croix. Gestation would occur from January through April during the dry season, with parturition at the beginning of the wet season in May. Our latest record for a lactating female was 2 August, but some individuals probably lactate throughout August. There does not seem to be evidence of a post-partum estrus. We agree with Krutzch and Nellis (2006; see also Wilson 1973, 1979, and Swanepoel and Genoways 1983) that the reproductive cycle of $B$. cavernarum is best described as synchronous, seasonal monestry.

Six pregnant females taken in March had an average weight of 43.8 (40.4-49.4), whereas an adult male from this time weighed 40.9. In mid-June, six lactating females had a mean weight of 44.3 (42.1-46.7), whereas six non-reproductive males weighed an average 43.6 (39.4-50.3). A lactating female obtained in early August weighed 42.0 and five non-reproductive females had the same mean weight of 42.0 (38.4-45.1). In early August, a scrotal male weighed 47.7 and three males with testes in an inguinal position weighed 38.6, 45.4, and 45.6. Omitting the pregnant females, it appears that the sexes averaged approximately the same weights.

\section{Sturnira paulsoni luciae Jones and Phillips, 1976}

Paulson's Yellow-shouldered Bat

Specimens examined (31). - Castries: Barre de l'Isle Ridge, $0.5 \mathrm{~km} \mathrm{~S}, 1.3 \mathrm{~km}$ E Rivine Poisson, 294 m [135'ㄴ'35.3"N, 6057'32.0"W], 3 (TTU 110607-09); Forestière Forest Trailhead, $0.5 \mathrm{~km} \mathrm{~S}, 0.5 \mathrm{~km}$ E Forestière, $300 \mathrm{~m}\left[13^{\circ} 58^{\prime} 11.2^{\prime \prime} \mathrm{N}, 60^{\circ} 57^{\prime} 08.8^{\prime \prime} \mathrm{W}\right], 1$ (TTU 110596); 1.5 km E Marigot Bay, 1 (UNSM 16488); Piton Flore, Forestière Forest Trail, $1.2 \mathrm{~km} \mathrm{~S}, 1.9 \mathrm{~km}$ E Forestière, $300 \mathrm{~m}\left[13^{\circ} 57^{\prime} 51.6^{\prime \prime} \mathrm{N}, 60^{\circ} 56^{\prime} 24.0^{\prime \prime} \mathrm{W}\right], 2$ (TTU 110597-98). Dauphin: $0.5 \mathrm{mi}$ SE Boguis, $100 \mathrm{ft}$, 7 (KU 110135-41). Gros Islet: Union Agricultural Station, $100 \mathrm{ft}, 1$ (KU 110134). Laborie: $1.25 \mathrm{~km} \mathrm{~N}, 0.75$

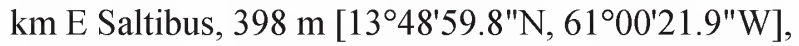
1 (TTU 113315). Micoud: Quilesse Forest Reserve,

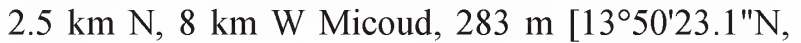
6058'25.8"W], 8 (TTU 109259-60, 110599-604). Praslin: Mamiku River, $1.1 \mathrm{~km} \mathrm{~N}, 0.2 \mathrm{~km}$ E Mon

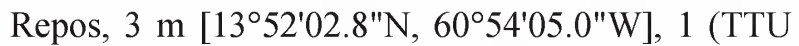
110605); Raillon Negres, $1.2 \mathrm{~km} \mathrm{~N}, 2.3 \mathrm{~km} \mathrm{~W}$ Mon

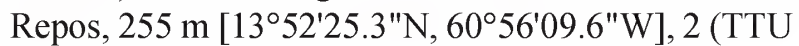


109255, 110606). Soufrière: Diamond Botanical Garden, Diamond, $47 \mathrm{~m}$ [13⒌ $\left.51^{\prime} 08.7^{\prime \prime} \mathrm{N}, 61^{\circ} 02^{\prime} 57.5^{\prime \prime} \mathrm{W}\right]$, 1 (TTU 109256). Vieux Fort: Woodlands Estate,

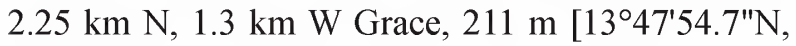
6058'50.7"W], 3 (TTU 109257-58, 110610).

Additional records (Clarke 2009, unless noted otherwise).- Anse La Raye: "Anse La Raye" [= Venus Estate] [converted from UTM, 13⒌ $55^{\prime} 14.7^{\prime \prime N}$, $\left.61^{\circ} 01^{\prime} 12.1 " \mathrm{~W}\right]$; Millet Forest [= Millet Bird Sanctuary] [converted from UTM, 135' $53^{\prime} 44.7^{\prime \prime} \mathrm{N}, 60^{\circ} 59^{\prime} 50.2^{\prime \prime} \mathrm{W}$ ]. Castries: Barre de l'Isle Ridge. Choiseul: River Dorée [converted from UTM, 134ㅇ' $05.1^{\prime \prime} \mathrm{N}, 61^{\circ} 01^{\prime} 54.6^{\prime \prime} \mathrm{W}$ ]. Micoud: Des Cartier Rainforest Trail [converted from UTM, 1350'24.2"N, 6048'45.9"W]. Praslin: "Durocher" [= Morne Durocher] [converted from UTM, 13 $\left.52^{\prime} 34.4^{\prime \prime} \mathrm{N}, 60^{\circ} 56^{\prime} 12.5^{\prime \prime} \mathrm{W}\right]$. Soufrière: Anse Chastanet [converted from UTM, 13 ${ }^{\circ} 52^{\prime} 00.9^{\prime \prime} \mathrm{N}$, $\left.61^{\circ} 04^{\prime} 10.3 " \mathrm{~W}\right]$. No Specific Quarter: no specific locality (Jones and Phillips 1970).

Specimens captured/released (45)._Castries: Barre de l'Isle Ridge, $0.5 \mathrm{~km} \mathrm{~S}, 1.3 \mathrm{~km}$ E Rivine

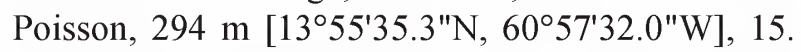
Piton Flore, Forestière Forest Trail, $1.2 \mathrm{~km} \mathrm{~S}, 1.9 \mathrm{~km}$ E Forestière, $300 \mathrm{~m}\left[13^{\circ} 57^{\prime} 51.6^{\prime \prime} \mathrm{N}, 60^{\circ} 56^{\prime} 24.0^{\prime \prime} \mathrm{W}\right]$, 2. Dennery: Au Leon Peak, $1 \mathrm{~km} \mathrm{~N}, 1.75 \mathrm{~km} \mathrm{E} \mathrm{La}$ Ressource, 319 m [135' $\left.14.4^{\prime \prime} \mathrm{N}, 60^{\circ} 54^{\prime} 07.1^{\prime \prime} \mathrm{W}\right], 1$. Micoud: Quilesse Forest Reserve, $2.5 \mathrm{~km} \mathrm{~N}, 8 \mathrm{~km}$

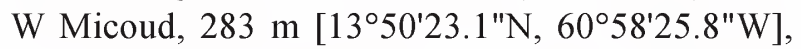
10. Praslin: Raillon Negres, $1.2 \mathrm{~km} \mathrm{~N}, 2.3 \mathrm{~km} \mathrm{~W}$ Mon Repos, 255 m [135' $\left.25.3^{\prime \prime} \mathrm{N}, 60^{\circ} 56^{\prime} 09.6^{\prime \prime} \mathrm{W}\right]$, 10. Soufrière: Edmund Forest Reserve, $0.7 \mathrm{~km} \mathrm{~N}$, $1.5 \mathrm{~km}$ E Fond St. Jacques, $550 \mathrm{~m}\left[13^{\circ} 50^{\prime} 27.9^{\prime \prime} \mathrm{N}\right.$, 605' $47.6 " \mathrm{~W}]$, 5. Vieux Fort: Woodland Estate,

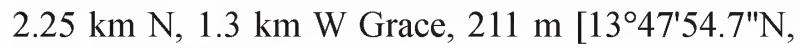
$60^{\circ} 58$ '50.7"W], 2.

Bats of the genus Sturnira are known from the Lesser Antilles from Montserrat (Pedersen et al. 1996) southward to Grenada (Genoways et al. 1998), but they are absent on Barbados and the Grenadines. Kwiecinski et al. (2018) recently reviewed the morphological (de la Torre 1966; de la Torre and Schwartz 1966; Jones and Phillips 1976; Genoways 1998) and molecular (Velazco and Patterson 2013) studies of Antillean Sturnira, which have resulted in major taxonomic changes. The morphological studies recognized two species occur- ring on the Lesser Antillean islands. The endemic $S$. thomasi was restricted to the islands of Guadeloupe and Montserrat, whereas several subspecies of $S$. lilium were found from Dominica southward to South America. The molecular study conducted by Velazco and Patterson (2013) resulted in a significantly different taxonomic arrangement with two endemic species occupying the Lesser Antillean islands. The northern endemic, $S$. angeli, was recognized on the islands of Montserrat, Guadeloupe, Dominica, and Martinique, whereas S. paulsoni was recognized on St. Lucia, St. Vincent, and Grenada. Kwiecinski et al. (2018) reviewed the discordance between the morphological and molecular data, but they "followed the taxonomy of the molecular study because it was comprehensive and most recently conducted." We have followed this arrangement herein as well using the scientific name $S$. p. luciae for the population on St. Lucia. We recommend additional genomic studies aimed at examining recently evolved reproductive and/or genetic isolating mechanisms in Caribbean Sturnira.

Our analyses of the length of forearm and seven cranial measurements for 14 male and 10 female Sturnira collected on St. Lucia revealed that males averaged larger than females for all measurements except length of maxillary toothrow, which was the same for both sexes (Table 1). The greatest length of skull and condylobasal length were significantly $(P \leq 0.01)$ larger in males, but no significant secondary sexual dimorphism was found in the remaining six measurements.

Five Sturnira were netted while foraging in dry forest on the Woodland Estate (Fig. 10). This site was along a ridge top above the coastal lowlands of southern St. Lucia. Native trees were bearing small fruits (18 June 2007) many of which were evident on the ground. Nets were placed across the Estate road, at the head of ravines intersecting the road, and around a stand of pepper plants. Only two other species were captured at this site $-M$. plethodon (4) and A. jamaicensis $\times$ schwartzi (34).

It was interesting to compare two sites that we worked on the successive nights of 29 and 30 July 2008 in the Quarter of Praslin. The Mamiku River site was the lowest elevation (3 m) where we caught Sturnira. The original vegetation in the area would have been dry 


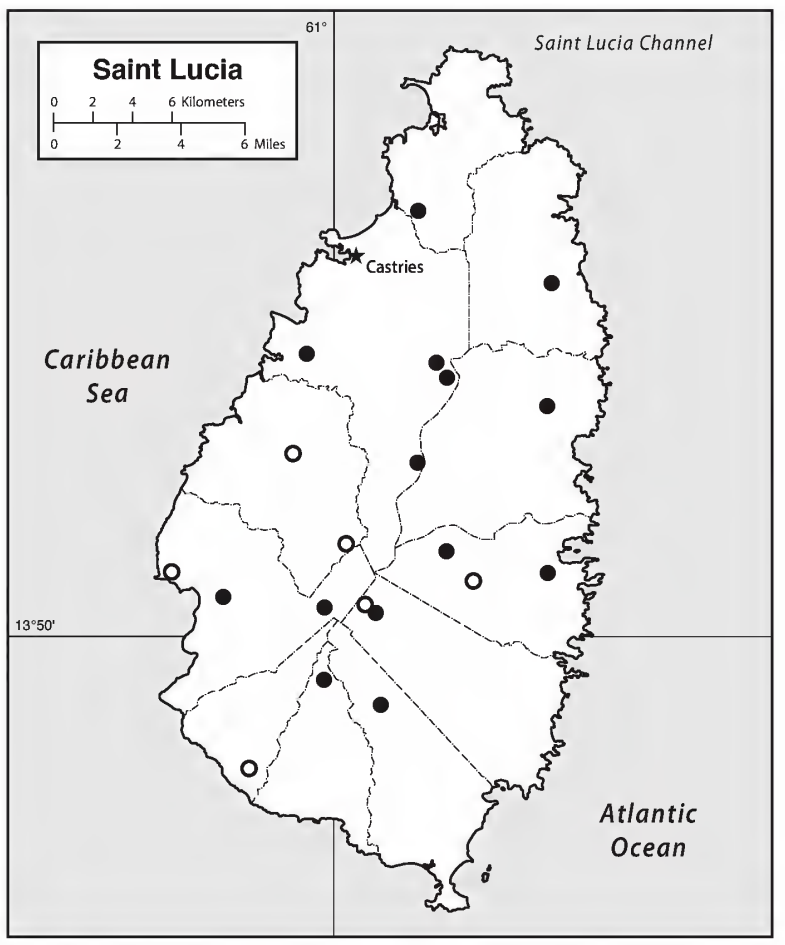

Figure 10. Map of the geographic distribution of Sturnira paulsoni on the Lesser Antillean island of St. Lucia. Symbols include: closed circles represent specimens examined and open circles represent literature records.

lowland scrub woodland, but much of this vegetation had been replaced by various buildings, a small resort, small banana plantations, ornamental plantings, a small botanical garden (Mamiku Garden), fruit trees such as guava, guinep, soursop, almond, and mango, and low brushy secondary forest trees. Some of the trees in Mamiku Garden that could be of value to bats include bay leaf, white cedar, and buttercup tree. A single net was placed across a large pond in the riverbed. Bat activity was quite low at this site. In addition to our capture of a single Sturnira, two other species of bat were netted at this site including A. jamaicensis $\times$ schwartzi (9), and M. molossus (3). About $5 \mathrm{~km}$ west of the Mamiku River location we netted at a much higher elevation $(255 \mathrm{~m})$ in lower montane rainforest near Raillon Negres. This habitat included common trees such as bois de masse, balata chien, candlewood, and bois cote. Forest edge species included pepper plant, gumtree, and bwa kannon. We netted 12 Sturnira in five mist nets that we had placed across the access road and in the adjacent forest. We netted Sturnira at elevations ranging from 3 to $550 \mathrm{~m}$, however, 57 of the 68 captures $(84 \%)$ were netted in a narrow band of elevations ( $200-300 \mathrm{~m}$ ), and $95 \%$ of captures were above $200 \mathrm{~m}$. This distribution coincides with that of wet/moist forests and their associated foraging opportunities located in the interior of the island. Four other species of bats were netted near Raillon Negres, including P. davyi (1), M. plethodon (7), A. jamaicensis $\times$ schwartzi (67), and M. molossus (1).

The Edmund Forest Reserve (Fig. 11) was the highest elevation site that we worked. Beard (1949) classified the vegetation in this reserve as secondary rainforest. On 1 August 2008, seven mist nets were located near the top of the forest road where it intersected with the access road to a radio tower. Many ornamental plants and cultivated fruit trees were associated with a building about $300 \mathrm{~m}$ below the intersection. Two additional nets were placed along what remained of a colonial era road that ascended the ridge before descending to the Caribbean side of the island. Of interest, this was one of the three sites where we netted seven of the nine species known from the island: $B$. cavernarum, $P$. davyi, M. plethodon, A. jamaicensis $\times$ schwartzi, S. paulsoni, M. molossus, and T. brasiliensis. If we include the Noctilio and Ardops captured by Clarke (2009) on the Des Cartier Rainforest Trail, all nine species of bat from the island were found within the Edmund Forest Reserve.

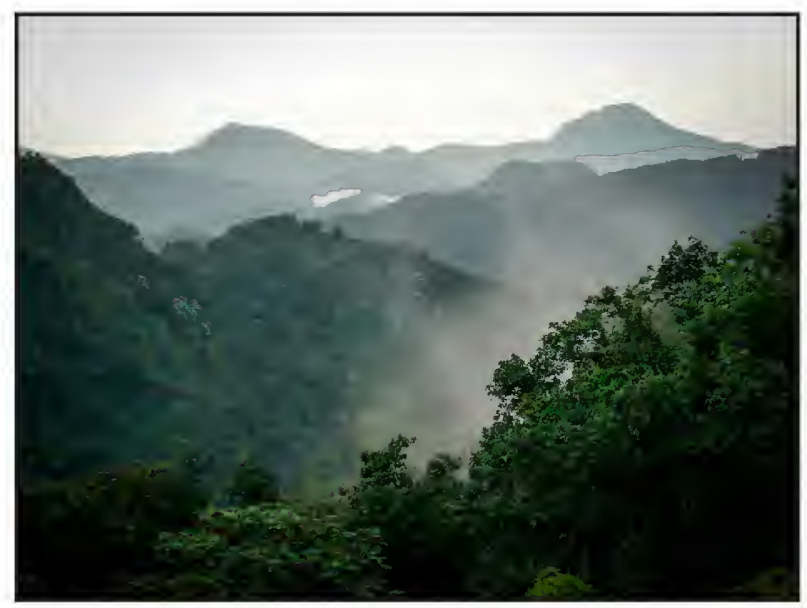

Figure 11. Photograph of the Edmund Forest Reserve, Soufrière Quarter, St. Lucia. The nine known species of bats occurring on St. Lucia were taken in this forest reserve. 
Between 15 and 17 March 2009, three Sturnira were captured, of which two were females - one was pregnant with an embryo that was 4 in crown-rump length and the other revealed no gross reproductive activity. The scrotal male had testes that measured 6 in length. A female taken on 24 May 1987 was lactating. In mid-June 2007 (17 to 20), 10 females were netted of which seven were lactating, two were pregnant, with one embryo measuring 8 in crown-rump length, and one was post-lactating. Three males had testes length measurements of 2,5 , and 8 , with the former being a subadult having testes in an inguinal position. During the peak of the rainy season in late July-early August, 23 females evinced no gross reproductive activity, eight were pregnant, with three of the embryos measuring 17,22 , and 24 in crown-rump length, and three females were lactating. Sixteen males were obtained during this period, with three having testes in scrotal position (one testes length of 6), and 13 with testes in inguinal position, average testes length of five individuals, 2.8 (2-4). A small sample of Sturnira was taken in the period of 26 to 28 August 1967 . Three females were included in the sample with two pregnant carrying embryos that measured 24 and 26 in crown-rump length and the third lactating. Five scrotal males had testes that averaged $5.6(4-7)$ in length.

Wilson (1979) believed that mainland populations of Sturnira followed a bimodal polyestrous reproductive cycle. Our data from St. Lucia would appear to fit this pattern. Our March sample was very small, but it did include one pregnant female. Most females had undergone parturition before our work in mid-June, with $70 \%$ of the females lactating, but two were pregnant, which we believe was the result of a postpartum estrus. During the rainy season in July and early August, eight females were pregnant and three were lactating, but about $67 \%$ of females showed no gross reproductive activity so the postpartum breeding did not include the entire population. Although the late August data for females was limited, they were still reproducing at that time. Most males at beginning of August appeared to be reproductively inactive, but the males in the late August sample appeared to be ready for sexual activity.

On St. Lucia, a pregnant female weighed 16.2, a non-pregnant female weighed 19.4 , and a scrotal male weighed 19.6 when captured between 15 to 17 March
2009. Two pregnant females weighed 19.0 and 25.2, seven lactating females had a mean weight of 18.0 (16.6-21.1), one post-lactating female had a weight of 20.0, and two scrotal males weighed 21.2 and 23.0 when netted 17 to 20 June 2007. From 30 July to 4 August 2008, nine non-reproductive females had a mean weight of 19.2 (17.8-22.7), a lactating female had a weight of 21.2, and five pregnant females had an average weight of $22.2(20.5-24.5)$. Weights of males from this time period were 18.3 for a scrotal male with weights of $16.2,18.2,18.4$, and 18.4 for four males with testes in a non-scrotal position. These data indicate that there was little difference in the weights of males and females when pregnant females were excluded from consideration.

\section{Artibeus jamaicensis $\times$ schwartzi Jamaican Fruit-eating Bat (hybrid)}

Specimens examined (242).-Anse La Raye: Anse La Raye; $1 \mathrm{~m}$ [13 $\left.{ }^{\circ} 56^{\prime} 30.3^{\prime \prime} \mathrm{N}, 61^{\circ} 02^{\prime} 28.2^{\prime \prime} \mathrm{W}\right]$, 8 (TTU 109409-16). Castries: Barre de l'Isle Ridge, $0.5 \mathrm{~km} \mathrm{~S}, 1.3 \mathrm{~km}$ E Rivine Poisson, $294 \mathrm{~m}$

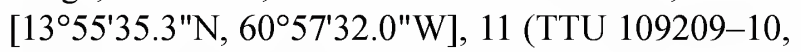
109248, 109440-44, 109518-20); Cul de Sac River, south bank, west slope of Barre de l'Isle Ridge [probably near Deglos at $\left.\approx 13^{\circ} 58^{\prime} 29.14^{\prime \prime} \mathrm{N}, 60^{\circ} 58^{\prime} 36.0^{\prime \prime} \mathrm{W}\right]$, 2 (AMNH 239588-89); Forestière Forest Trailhead, $0.5 \mathrm{~km} \mathrm{~S}, 0.5 \mathrm{~km}$ E Forestière, $300 \mathrm{~m}\left[13^{\circ} 58^{\prime} 11.2^{\prime \prime} \mathrm{N}\right.$, $\left.60^{\circ} 57^{\prime} 08.8^{\prime \prime} \mathrm{W}\right], 4$ (TTU 109434-37); Piton Flore, Forestière Forest Trail, $1.2 \mathrm{~km} \mathrm{~S}, 1.9 \mathrm{~km}$ E Forestière, 300 $\mathrm{m}$ [135' 51.6"N, 6056'24.0"W], 2 (TTU 109438-39); 1.5 km E Marigot Bay, 26 (UNSM 16490-92, 1654062); Marigot Bay, 36 (UNSM 16720-29,16731-49, 16782-88); Union Nature Trail, $0.6 \mathrm{~km} \mathrm{~N}, 0.5 \mathrm{~km} \mathrm{~W}$

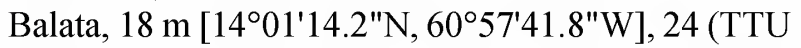
109205-06, 109237-41, 109417-33). Dauphin:

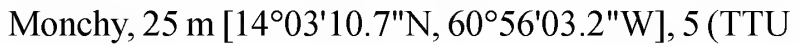
110989-93); Ruins of Marquis Estate, $1.6 \mathrm{~km} \mathrm{~N}, 0.8$ $\mathrm{km}$ E Boguis, $25 \mathrm{~m}\left[14^{\circ} 01^{\prime} 35.2^{\prime \prime} \mathrm{N}, 60^{\circ} 54^{\prime} 40.6^{\prime \prime} \mathrm{W}\right], 6$ (TTU 109207-08, 109242-43, 109445-46). Dennery: Au Leon Peak, 1 km N, 1.75 km E La Ressource, 319 $\mathrm{m}$ [13 $\left.{ }^{\circ} 57^{\prime} 14.4^{\prime \prime} \mathrm{N}, 60^{\circ} 54^{\prime} 07.1 " \mathrm{~W}\right], 8$ (TTU 110941-48); Dennery River, $0.25 \mathrm{~km} \mathrm{~S}, 2 \mathrm{~km}$ W Dennery, $11 \mathrm{~m}$ [135'ㄴ․․" N, 6054'16.2"W], 4 (TTU 109447-50). Gros Islet: Union Agriculture Station, $100 \mathrm{ft}, 13$ (KU 110159-69, 110172-73). Laborie: $1.25 \mathrm{~km} \mathrm{~N}, 0.75$ km E Saltibus, 398 m [134' $\left.59.8^{\prime \prime} \mathrm{N}, 61^{\circ} 00^{\prime} 21.9^{\prime \prime} \mathrm{W}\right]$, 
2 (TTU 110949-50). Micoud: Canelles River, $1.5 \mathrm{~km}$ S Anse Ger, 10 m [134' $\left.59.6^{\prime \prime} \mathrm{N}, 60^{\circ} 54^{\prime} 53.1^{\prime \prime} \mathrm{W}\right], 12$ (TTU 109474-85); Quilesse Forest Reserve, $2.5 \mathrm{~km} \mathrm{~N}$,

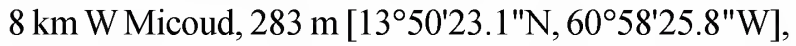
13 (TTU 109461-73); Troumassee River, $1.3 \mathrm{~km} \mathrm{~W}$ Micoud, 40 m [134' 13.9"N, 6054'53.7"W], 10 (TTU 109451-60). Praslin: Fox Grove Inn, 1.1 km N, 0.2 km

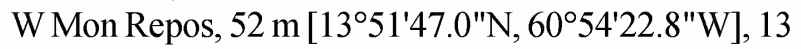
(TTU 109486-98); Mamiku River, $1.1 \mathrm{~km} \mathrm{~N}, 0.2 \mathrm{~km}$ E Mon Repos, 3 m [13 $\left.52^{\prime} 02.8^{\prime \prime} \mathrm{N}, 60^{\circ} 54^{\prime} 05.0^{\prime \prime} \mathrm{W}\right], 9$ (TTU 109499-507); Raillon Negres, $1.2 \mathrm{~km} \mathrm{~N}, 2.3 \mathrm{~km}$ W Mon Repos, 255 m [1352'25.3"N, 6056'09.6"W], 10 (TTU 109509-17, 116545). Soufrière: Diamond Botanical Garden, Diamond, $47 \mathrm{~m}\left[13^{\circ} 51^{\prime} 08.7^{\prime \prime} \mathrm{N}\right.$, $61^{\circ} 02 ' 57.5^{\prime \prime W}$ ], 5 (TTU 110951-55); Edmund Forest Reserve, $0.7 \mathrm{~km} \mathrm{~N}, 1.5 \mathrm{~km}$ E Fond St. Jacques, $550 \mathrm{~m}$ [1350'27.9"N, 6059'47.6"W], 12 (TTU 109521-32). Vieux Fort: Woodland Estate, $2.25 \mathrm{~km} \mathrm{~N}, 1.3 \mathrm{~km} \mathrm{~W}$

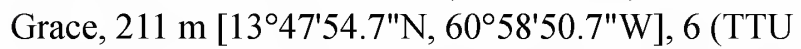
109244-47, 109533-34). No Specific Quarter: no specific locality, 1 (NMNH 106014).

Additional records (Clarke 2009, unless otherwise noted).-Anse La Raye: "Anse La Raye" [= Venus Estate] [converted from UTM, 13⒌'14.7"N, $\left.61^{\circ} 01^{\prime} 12.1^{\prime \prime} \mathrm{W}\right]$; Millet Forest [= Millet Bird Sanctuary] [converted from UTM, 135' $53^{\prime} 44.7^{\prime \prime} \mathrm{N}, 60^{\circ} 59^{\prime} 50.2^{\prime \prime} \mathrm{W}$ ]. Castries: Barre de l'Isle Ridge, $0.5 \mathrm{~km} \mathrm{~S}, 1.3 \mathrm{~km} \mathrm{E}$

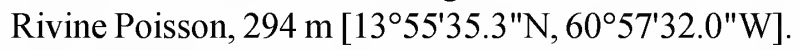
Choiseul: River Dorée [converted from UTM, $13^{\circ} 46^{\prime} 05.1$ "N, 6101'54.6"W]. Dauphin: Sorcière River [converted from UTM, $14^{\circ} 01^{\prime} 26.6^{\prime \prime} \mathrm{N}$, $60^{\circ} 54^{\prime} 33.2^{\prime \prime} \mathrm{W}$ ]. Laborie: near Piaye [converted from UTM, 134' $\left.05.1^{\prime \prime} \mathrm{N}, 61^{\circ} 01^{\prime} 54.6 " \mathrm{~W}\right]$. Micoud: Des Cartier Rainforest Trail [converted from UTM, $13^{\circ} 50^{\prime} 24.2^{\prime N}, 60^{\circ} 48^{\prime} 45.9^{\prime \prime} \mathrm{W}$ ]. Praslin: "Durocher" [= Morne Durocher] [converted from UTM, $13^{\circ} 52^{\prime} 34.4^{\prime \prime} \mathrm{N}$, $\left.60^{\circ} 56^{\prime} 12.5^{\prime \prime} \mathrm{W}\right]$. Soufrière: Edmund Forest Reserve. No Specific Quarter: no specific locality (Koopman 1968; Jones and Phillips 1970; Jones 1978).

Specimens captured/released (791).-Castries: Barre de l'Isle Ridge, $0.5 \mathrm{~km} \mathrm{~S}, 1.3 \mathrm{~km}$ E Rivine

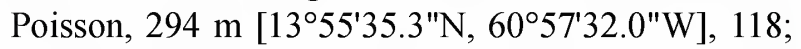
Forestière Forest Trailhead, $0.5 \mathrm{~km} \mathrm{~S}, 0.5 \mathrm{~km}$ E Forestière, $300 \mathrm{~m}\left[13^{\circ} 58^{\prime} 11.2^{\prime \prime} \mathrm{N}, 60^{\circ} 57^{\prime} 08.8^{\prime \prime} \mathrm{W}\right], 62$; Piton Flore, Forestière Forest Trail, $1.2 \mathrm{~km} \mathrm{~S}, 1.9 \mathrm{~km}$ E Forestière, $300 \mathrm{~m}\left[13^{\circ} 57^{\prime} 51.6^{\prime \prime} \mathrm{N}, 60^{\circ} 56^{\prime} 24.0^{\prime \prime} \mathrm{W}\right]$,
22; Union Nature Trail, $0.6 \mathrm{~km} \mathrm{~N}, 0.5 \mathrm{~km} \mathrm{~W}$ Balata,

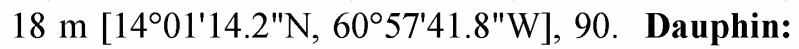

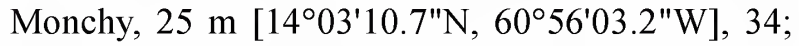
Ruins of Marquis Estate, $1.6 \mathrm{~km} \mathrm{~N}, 0.8 \mathrm{~km}$ E Boguis, $25 \mathrm{~m}\left[14^{\circ} 01^{\prime} 35.2^{\prime \prime} \mathrm{N}, 60^{\circ} 54^{\prime} 40.6^{\prime \prime} \mathrm{W}\right], 12$. Dennery: Au Leon Peak, 1 km N, 1.75 km E La Ressource, 319 m [13 $\left.57^{\prime} 14.4^{\prime \prime N}, 60^{\circ} 54^{\prime} 07.1 " \mathrm{~W}\right], 10$; Dennery River,

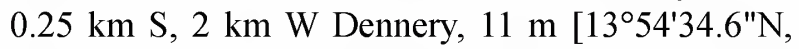
$\left.60^{\circ} 54^{\prime} 16.2^{\prime \prime} \mathrm{W}\right], 23$. Laborie: $1.25 \mathrm{~km} \mathrm{~N}, 0.75 \mathrm{~km}$

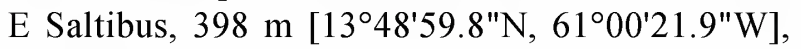
1. Micoud: Canelles River, $1.5 \mathrm{~km} \mathrm{~S}$ Anse Ger,

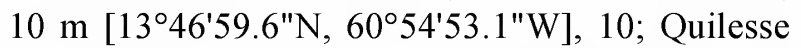
Forest Reserve, $2.5 \mathrm{~km} \mathrm{~N}, 8 \mathrm{~km} \mathrm{~W}$ Micoud, 283

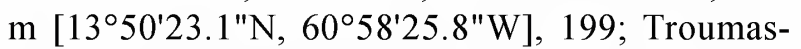
see River, $1.3 \mathrm{~km}$ W Micoud, $40 \mathrm{~m}\left[13^{\circ} 49^{\prime} 13.9^{\prime \prime} \mathrm{N}\right.$, $\left.60^{\circ} 54^{\prime} 53.7^{\prime \prime} \mathrm{W}\right], 73$. Praslin: Fox Grove Inn, 1.1

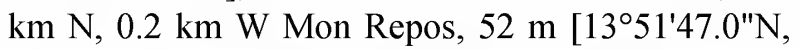
$60^{\circ} 54^{\prime 22.8 " W], ~ 5 ; ~ R a i l l o n ~ N e g r e s, ~} 1.2 \mathrm{~km} \mathrm{~N}, 2.3 \mathrm{~km} \mathrm{~W}$ Mon Repos, 255 m [135'ㄹ' 25.3"N, 6056'09.6"W], 57. Soufrière: Diamond Botanical Garden, Diamond, 47 $\mathrm{m}$ [13⒌ $\left.51^{\prime} 08.7^{\prime \prime} \mathrm{N}, 61^{\circ} 02^{\prime} 57.5^{\prime \prime} \mathrm{W}\right], 33$; Edmund Forest Reserve, $0.7 \mathrm{~km} \mathrm{~N}, 1.5 \mathrm{~km}$ E Fond St. Jacques, 550 m [13 $\left.50^{\circ} 27.9^{\prime \prime} \mathrm{N}, 60^{\circ} 59^{\prime} 47.6^{\prime \prime} \mathrm{W}\right]$, 14. Vieux Fort: Woodland Estate, $2.25 \mathrm{~km} \mathrm{~N}, 1.3 \mathrm{~km} \mathrm{~W}$ Grace, $211 \mathrm{~m}$ [13ํำ $\left.54.7^{\prime \prime} \mathrm{N}, 60^{\circ} 58^{\prime} 50.7^{\prime \prime} \mathrm{W}\right], 28$.

The St. Lucian population of Artibeus resides at the northern edge of a remarkable hybrid zone involving three species, $A$. jamaicensis, $A$. planirostris, and $A$. schwartzi (P. Larsen et al. 2010; also see $A$. schwartzi species account in Kwiecinski et al. 2018). This hybrid zone likely formed within the last $\sim 15,000$ years and was the result of primary contact among multiple genetic lineages of Artibeus that converged in the southern Lesser Antilles. Phillips et al. $(1989,1991)$ and Pumo et al. $(1988,1996)$ identified the presence of both A. jamaicensis and A. schwartzi mitochondrial haplotypes within the St. Lucian population of Artibeus. The most recent genetic and morphological data from St. Lucian specimens of Artibeus $(\mathrm{n}=17)$ was presented in P. Larsen et al. (2010) and these data consist of AFLPs, mitochondrial DNA sequence data, and 17 cranial and mandibular measurements. Collectively, these data indicated the presence of sympatric phenotypes of A. jamaicensis and A. schwartzi on St. Lucia as well as putative F1 and F2 hybrids. Nevertheless, the majority of specimens collected from St. Lucia exhibit morphological characteristics that are typical of 
A. jamaicensis (see below). When considering active hybridization between $A$. jamaicensis and $A$. schwartz $i$ (as hypothesized by Larsen et al. 2010), we posit that A. jamaicensis $\times$ schwartzi is the most appropriate taxonomic assignment for St. Lucian Artibeus, pending additional genomic and morphometric data.

The length of forearm and seven cranial measurements for 10 males and 14 females (Table 1) of these hybrid Artibeus revealed no sexual secondary dimorphism in the St. Lucia population. Average measurements for males were greater for greatest length of skull and postorbital constriction, average measurements for females were greater for length of forearm, condylobasal length, and breadth across upper molars, and average measurements were the same for zygomatic breadth, mastoid breadth, and length of maxillary toothrow.

Genoways et al. (2010) reviewed data concerning variation in the presence/absence of the upper M3 and lower $\mathrm{m} 3$ in Antillean populations of Artibeus but lacked information for those from St. Lucia. They concluded that the presence/absence of the upper M3 was a species-level character, whereas presence/absence of the lower $\mathrm{m} 3$ in this Artibeus complex was neither an indication of geographic variation nor a specieslevel character, but rather it was a low occurrence polymorphism. We examined 24 individuals from St. Lucia finding all lacking the upper M3. Populations of Artibeus from the Bahamas through the Greater Antilles and south at least far as Dominica in the Lesser Antilles to which we would now apply the name $A$. jamaicensis uniformly lacked the upper third molars. Populations on Trinidad are considered to be A. planirostris and $100 \%$ of the individuals examined have the upper M3 present. In the Grenada population, $89 \%$ of the individuals have the upper $\mathrm{M} 3$ indicating a strong relationship with $A$. planirostris, but also suggesting some genetic introgression from A. jamaicensis. Further north in the Grenadine Islands the overall rate of occurrence of the upper M3 was only $3.6 \%$, but the rate of occurrence of the upper M3 was higher again on St. Vincent (11.6\%), associating a low rate of occurrence of M3 with $A$. schwartzi. This places the population on St. Lucia with the characteristics of $A$. jamaicensis, which lies to the north. We do not have data for Martinique populations, but on the next island to the north, Dominica, 100\% of 97 individuals examined lacked the upper M3 (Genoways et al. 2010). This makes the population on St. Lucia the second along with Barbados (Genoways et al. 2010, 2011) in which molecular data would place them with a relationship with $A$. schwartzi (Pumo et al. 1988, 1996; P. Larsen 2007, 2010), whereas the upper M3 findings indicate a relationship with $A$. jamaicensis. We also examined these 24 individuals for the occurrence of the lower $m 3$, finding that 21 had both lower $\mathrm{m} 3$ present, two were missing both lower $\mathrm{m} 3$, and one individual was missing the left lower $\mathrm{m} 3$ (counted as an absence). This gives a result of $87.5 \%$ presence or $12.5 \%$ absence of the $\mathrm{m} 3$ in the St. Lucia population, which was a high rate for this polymorphism, matched or exceeded only by populations on Antigua, Barbuda, and St. Kitts (Genoways et al. 2010).

These hybrid Artibeus were the most commonly caught species during our 1987-2009 survey efforts, representing $65 \%$ of all captures. These bats were captured at all localities where nets were set, from 3 $\mathrm{m}$ (Mamiku River) to $550 \mathrm{~m}$ (Edmund Forest Reserve) (Fig. 12). The abundance of this species cannot be understated - of the 294 bats snared in 11 nets set at Quilesse Forest Reserve, 212 were Artibeus (72\%, 19.3 Artibeus per net), the greatest number of this species caught at a single location during our work.

On the first night of our 2007 (14 June) field season we caught 114 Artibeus and nine Molossus near the headquarters of the Forestry Department, Ministry of Agriculture, near Balata. We set three nets in the channel of the Choc River where there were standing pools of water. Six other nets were set along the Union Nature Trail including an area containing mango trees. The original vegetation in this area was lowland dry scrub woodland, but it has mostly been removed as the city of Castries has advanced in this direction.

We netted at two sites near Marigot Bay on the nights of 24-25 May 1987, during studies focusing on the genetics of this Artibeus complex (Pumo et al. 1988, 1996; Phillips et al. 1989, 1991). We obtained 26 individuals of Artibeus on the first night east of Marigot Bay and 36 the next night in the resort area adjacent to the bay. The general vegetation in the area was typical lowland dry scrub woodland. East of Marigot Bay, we set four nets in and around a banana plantation and the 


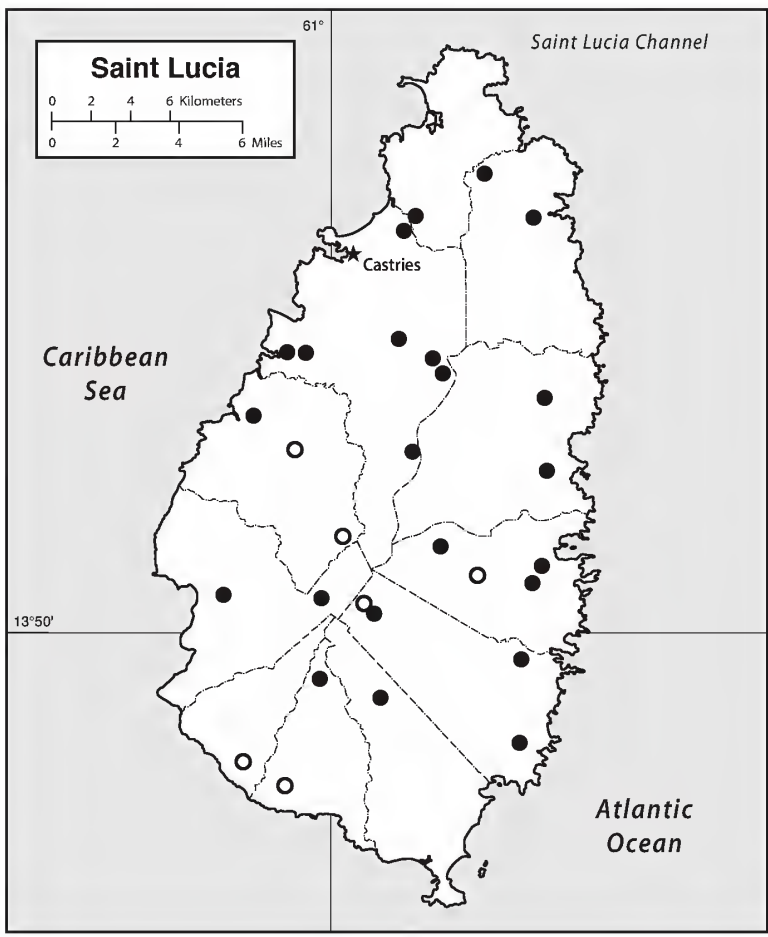

Figure 12. Map of the geographic distribution of Artibeus jamaicensis $\times$ schwartzi on the Lesser Antillean island of St. Lucia. Symbols include: closed circles represent specimens examined and open circles represent literature records.

adjacent woodland. In the settlement of Marigot Bay, ornamental and fruit trees were very common, including those that could be used by bats such as mango, nutmeg, coconut, almond, and soursop. Four nets were placed within resort grounds in association with mango and almond trees. Four other species of bats were taken at these related sites: $B$. cavernarum at both sites, $S$. paulsoni at the east Marigot Bay site, and M. plethodon and M. molossus at the bay only.

We collected 83 Artibeus on the night of 30 July 2008 along the Troumassee River near Micoud. The lowland dry scrub woodland in this area had been heavily impacted by land clearing and the development of commercial banana plantations. Five nets were placed within a dense banana plantation and across the Troumassee River, the banks of which were badly eroded, with tree roots protruding from the banks. Most of the Artibeus were netted in the plantation along with a single $M$. plethodon. Over the river, we caught $M$. molossus (40) and T. brasiliensis (1).
Clarke (2009) reported that on the 19 February, two females were taken that appeared to be in an early stage of pregnancy, and three "late stage" palpably pregnant females were captured on 1 April (2) and 7 April (1). We have collected extensive reproductive data for this species-14 to 17 March 2009, during the dry season; 24 to 26 May 1987; 17 to 20 June 2007, as the rainy season was getting underway; and 30 July to 4 August 2008, as the rainy season was moving toward its height. Pregnant females were collected in each of these survey periods. In the dry season sample from March, a third (20 of 63) of the females were pregnant, with the remaining 43 females revealing no gross reproductive activity. Seven of the embryos had a mean crown-rump length of 26.1 (15-40), with the largest embryo having a forearm length of 24 and a weight of 10.9. It was noteworthy that no lactating or post-lactating adults or subadults (male or female) were present during this period. This suggests that there must have been a suspension of reproductive activity by these bats earlier in the dry season possibly as early as November and December.

As the dry season was ending and the rain was coming on in late May, over 59\% (10 of 17) of the females were pregnant, with embryos that averaged 17.7 (7-32) in crown-rump length. One of the pregnant females with a 9 crown-rump length embryo was also lactating, indicating to us that at least some of females were undergoing a postpartum estrus and breeding. Of the seven remaining females, two were lactating and five revealed no gross reproductive activity.

During June, over $85 \%$ of the adult females (148 of 173) examined were pregnant. Fifteen of these embryos averaged 21.9 (6-33) in crown-rump length. Of the remaining adults, 17 were lactating, one was postlactating, and seven revealed no reproductive activity. We also netted 40 subadult females during this time frame. These bats were fully engaged in reproductive activity by the early rainy season in June. However, the presence of volant subadults and the observation that $4 \%$ of the netted individuals were not reproductively active suggests that at least one cohort of young had been produced before June.

As the rainy season was reaching its peak in late July and the beginning of August these bats seem to be scaling back on reproductive activity. Only $16 \%$ 
of the adult females were pregnant (39 of 258), while over $57 \%$ (148 of 258 ) evinced no gross reproductive activity. Two of the embryos of the pregnant females measured 7 and 29, with the male embryo of the latter bat having a length of forearm of 12 . The remaining adult females were lactating (51), post-lactating (18), and post-lactating and pregnant (2). One of the latter embryos was 16 in crown-rump length. The sample also included five female subadults and one neonate. Although breeding had clearly slowed, births have been recorded in August and lactating females have been found in August and September.

The majority of the adult males had testes in a scrotal position and were prepared for breeding in each of our survey periods-March, $87.5 \%$ (21 of 24); May, $58 \%$ (7 of 12); June, $96 \%$ (73 of 76); and July-August, $84 \%$ (192 of 229). Testes lengths of four scrotal males taken in March were 9, 10, 10, and 11; mean testes lengths of seven scrotal males taken in May were 7.2 (6-9.5) and of five non-scrotal males was 5.6 (5-6); mean testes lengths of 20 scrotal males taken in June was 8.1 (6-10); and mean testes lengths of 38 scrotal males taken in July-August was 9.2 (3-14) and of seven non-scrotal males was 3.7 (3-5).

A collection of these bats taken on 26 August 1967 is housed the University of Kansas. Included in this material are seven adult females that exhibited no gross reproductive activity. Six scrotal males in this sample had a mean length of testes of 9.5 (5-13).

Studies beginning with those of Wilson (1979) and Wilson et al. (1991) characterized the reproductive cycle of $A$. jamaicensis as bimodal polyestry. Our studies on Barbados (Genoways et al. 2011), Dominica (Genoways et al. 2001), Grenada (Genoways et al. 1998), and the Grenadines (Genoways et al. 2010) indicate that Artibeus, through this hybrid zone, exhibit a similar bimodal polyestry. Although it was difficult to parse out the exact peaks of the bimodal cycle in our data from St. Lucia, these bats clearly were engaged in a high rate of reproduction, with most females producing at least two young per year.

The mean weight of 24 non-pregnant females taken in March was 42.6 (34.7-53.3), whereas 12 pregnant females taken at this time had an average weight of 49.1 (38.2-60.9). The mean weight of 16 scrotal males from March was 40.1 (34.8-49.8) and three non-scrotal males had weights of $38.2,41.7$, and 45.5. The following weights were recorded for bats captured during June: non-pregnant females, 33.7, 34.4 ; 16 pregnant females, 48.0 (39.8-60.9); lactating females, 43.1, 45.6, 48.2; post-lactating female, 38.7; subadult females, $37.2,42.5$; 20 scrotal males, 40.1 (34.1-43.7); non-scrotal male, 36.4; and subadult males, 29.4, 32.3, 36.7. The following weights were recorded for bats captured during July-August: 14 nonpregnant females, 38.4 (33.0-43.2); pregnant females, $46.8,49.0$; pregnant/post-lactating females, 44.3, 54.4; 24 lactating females, $42.4(35.6-46.5)$; post-lactating females, 35.6, 38.6, 41.5, 41.8; subadult females, 34.7, $34.9,42.0$; 39 scrotal males, 40.4 (34.7-48.0); seven non-scrotal males, 38.2 (34.5-41.2); and subadult males, 27.6, 30.3. Excluding the pregnant females and subadults, there seems to be no consistent difference between the weights of the sexes.

No gross abnormalities were observed in any of these bats, however, three had well-defined patches of white hair on a shoulder (Barre de l'Isle Ridge and Mamiku River, 2008) or on the rump (Union Nature Trail, 2007).

\section{Ardops nichollsi luciae (Miller, 1902) Antillean Tree Bat}

Specimens examined (25). - Castries: Barre de l'Isle Ridge, $0.5 \mathrm{~km} \mathrm{~S}, 1.3 \mathrm{~km}$ E Rivine Poisson, $294 \mathrm{~m}$

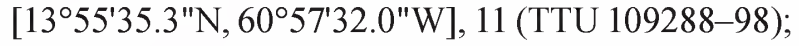
Forestière Forest Trailhead, $0.5 \mathrm{~km} \mathrm{~S}, 0.5 \mathrm{~km}$ E Forestière, $300 \mathrm{~m}\left[13^{\circ} 58^{\prime} 11.2^{\prime \prime} \mathrm{N}, 60^{\circ} 57^{\prime} 08.8^{\prime \prime} \mathrm{W}\right], 4$ (TTU 109281-84); Piton Flore, Forestière Forest Trail, 1.2 $\mathrm{km} \mathrm{S}, 1.9 \mathrm{~km}$ E Forestière, $300 \mathrm{~m}\left[13^{\circ} 57^{\prime} 51.6^{\prime \prime} \mathrm{N}\right.$, 6056'24.0"W], 3 (TTU 109285-87). Dennery: Au Leon Peak, $1 \mathrm{~km} \mathrm{~N}, 1.75 \mathrm{~km}$ E La Ressource, $319 \mathrm{~m}$

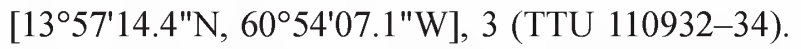
No Specific Quarter: no specific locality, 4 (NMNH 110917-20).

Additional records (Clarke 2009, unless otherwise noted).-Anse La Raye: Millet Forest [= Millet Bird Sanctuary] [converted from UTM, 13 ${ }^{\circ} 53^{\prime} 44.7^{\prime \prime} \mathrm{N}$, $\left.60^{\circ} 59^{\prime} 50.2^{\prime \prime} \mathrm{W}\right]$. Castries: Barre de l'Isle Ridge, 0.5 km S, 1.3 km E Rivine Poisson, 294 m [1355'35.3"N, 
$\left.60^{\circ} 57^{\prime} 32.0^{\prime \prime} \mathrm{W}\right]$. Micoud: Des Cartier Rainforest Trail [converted from UTM, 1350'24.2"N, 604 $48^{\prime} 45.9 \mathrm{~W}$ ]. No Specific Quarter: no specific locality (Miller 1902; Allen 1911; Jones and Schwartz 1967).

Specimens captured/released (4).-Castries: Barre de l'Isle Ridge, $0.5 \mathrm{~km} \mathrm{~S}, 1.3 \mathrm{~km}$ E Rivine Pois-

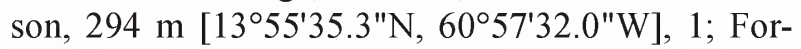
estière Forest Trailhead, $0.5 \mathrm{~km} \mathrm{~S}, 0.5 \mathrm{~km}$ E Forestière, $300 \mathrm{~m}\left[13^{\circ} 58^{\prime} 11.2^{\prime \prime} \mathrm{N}, 60^{\circ} 57^{\prime} 08.8^{\prime \prime} \mathrm{W}\right], 1$; Piton Flore, Forestière Forest Trail, $1.2 \mathrm{~km} \mathrm{~S}, 1.9 \mathrm{~km}$ E Forestière,

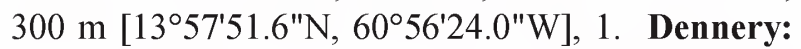
Au Leon Peak, 1 km N, 1.75 km E La Ressource, 319 $\mathrm{m}$ [13 $\left.57^{\circ} 14.4^{\prime \prime} \mathrm{N}, 60^{\circ} 54^{\prime} 07.1^{\prime \prime} \mathrm{W}\right], 1$.

Previously, Jones and Schwartz (1967) recognized five subspecies of Ardops nichollsi, where the subspecies luciae was comprised of specimens from St. Lucia and St. Vincent. In the most recent molecular and morphological analysis of Ardops, R. Larsen et al. (2017) found statistical support in a cyt- $b$ phylogeny for a sister relationship between St. Lucia and St. Vincent populations. However, those Ardops on St. Lucia ( $A$. $n$. luciae) had unique cyt- $b$ haplotypes that differed from all other Ardops. These data also provided evidence of a new subspecies from St. Vincent (A. $n$. vincentensis). Their AFLP data supported the later by identifying separate island-clades of Ardops from St. Lucia and St. Vincent (R. Larsen et al. 2017). Morphologically, specimens from St. Lucia had significantly larger cranial measurements than those from St. Vincent and were more similar in size to specimens from the northern islands (A. n. montserratensis, St. Martin through Guadeloupe). Together these findings provided strong support for the subspecies luciae on St. Lucia. The size of the Pleistocene island banks (Rojas et al. 2011; Baker et al. 2012) could have contributed to gene flow among populations of $A$. nichollsi in the northern Lesser Antilles but may have limited gene flow in populations distributed in the southern Lesser Antilles (St. Lucia and St. Vincent). In a 40,000-year fossil record on the small island of Marie Galante in the central Lesser Antilles, A. nichollsi does not appear until the Pleistocene-Holocene transition about 15,000 years ago (McCarthy and Henderson 1992; Stoetzel et al. 2016).

Table 1 presents length of forearm and seven cranial measurements for six male and 15 female Ardops from St. Lucia. There was considerable secondary sexual dimorphism in these bats on St. Lucia, as we have found in many other islands in the Lesser Antilles (Baker et al. 1978; Genoways et al. 2001; Kwiecinski et al. 2018). Females averaged larger than the males in all eight measurements. These differences were significant at $P \leq 0.05$ level for four measurements (length of forearm, greatest length of skull, mastoid breadth, and breadth across upper molars) and at the $P$ $\leq 0.001$ level for condylobasal length. The remaining three measurements (zygomatic breadth, postorbital constriction, and length of maxillary toothrow) did not test to be significantly different.

If we combine our capture data (2007-2009) with that of Clarke (2009), 41 of the 42 Ardops captured were netted at six locations within a very narrow range of elevations, 294-319 meters (Fig. 2).

We captured four Ardops at Piton Flore on the Forestière Forest Trail where it passes through an area of old secondary rainforest in the Castries Waterworks Forest Reserve. Some of the larger trees in this area were maho kockon, candlewood, bois de mass, bois cote, bitterwood, lansan, and swizzlestick tree. Five mist nets were set in this area of which two were placed across the trail, two in a ghut that intersected the trail, and one near the edge of the forest. Three other species taken here include M. plethodon (1), A. jamaicensis $\times$ schwartzi (24), and S. paulsoni (4).

Three females taken on 4 January 1901 (2) and 20 January 1901 (1) evinced no gross reproductive activity. A male collected on 4 February 1901 had testes in an inguinal position. On 17 March 2009, during the height of the dry season, we captured four Ardops of which one was pregnant with an embryo that measured 8 in crown-rump length and a second female revealed no gross reproductive activity. The two males taken on this evening had testes that measured 4 and 6 in length. A total of 14 Ardops were captured between 17 and 20 June 2007, which was a transition period from the dry season to the wet season on St. Lucia. Three females were obtained during this period-one was lactating, one was post-lactating, and one appeared to be reproductively inactive. Four scrotal males had a mean testes length of $5.6(5.0-6.0)$, whereas four males had testes in an inguinal position, with lengths of $4,4,4$, and 5. Seven males were netted on the night of 4 August 
2008, of which four had testes in scrotal position with length measurements of 4, 4, 4, and 5, whereas in the other three non-scrotal males two measured 3 and 5 in length. These reproductive data are inadequate for any comments on the reproductive cycle of Ardops, but the data were consistent with a bimodal polyestrous cycle proposed by Kwiecinski et al. (2018) for populations on St. Vincent.

A non-reproductive female taken in March weighed 17.1, whereas a pregnant female from this month weighed 20.5. Two males from March weighed 16.6 and 19.1. Three females taken in mid-June had the following weights: 19.1 (not reproductively active); 19.8 (lactating); and 22.0 (post-lactating). Eleven males taken in mid-June had a mean weight of 19.2 (17.5-21.4), whereas six males netted in early August had an average weight of 18.6 (17.9-19.9).

\section{Family Molossidae \\ Molossus molossus molossus (Pallas, 1776) Pallas's Mastiff Bat}

Specimens examined (61).-Castries: Castries, $25 \mathrm{ft}, 1$ (KU 110263); Forestière Forest Trailhead, $0.5 \mathrm{~km} \mathrm{~S}, 0.5 \mathrm{~km}$ E Forestière, $300 \mathrm{~m}\left[13^{\circ} 58^{\prime} 11.2^{\prime \prime N}\right.$, 6057'08.8"W], 1 (TTU 109927); Marigot Bay, 2 (UNSM 16566-67); Union Nature Trail, $0.6 \mathrm{~km} \mathrm{~N}$, $0.5 \mathrm{~km}$ W Balata, $18 \mathrm{~m}$ [14 $01^{\prime} 14.2^{\prime \prime} \mathrm{N}, 60^{\circ} 57^{\prime} 41.8^{\prime \prime} \mathrm{W}$, 9 (TTU 109918-109926). Dauphin: Ruins of Marquis Estate, $1.6 \mathrm{~km} \mathrm{~N}, 0.8 \mathrm{~km}$ E Boguis, $25 \mathrm{~m}$ [1401'35.2"N, 6054'40.6"W], 1 (TTU 109928); Mon-

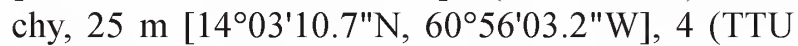
111450-53). Dennery: Au Leon Peak, 1 km N, $1.75 \mathrm{~km}$ E La Ressource, $319 \mathrm{~m}$ [135ํ'14.4"N, 6054'07.1"W], 1 (TTU 111454); Dennery River, $0.25 \mathrm{~km} \mathrm{S,} 2 \mathrm{~km} \mathrm{~W}$

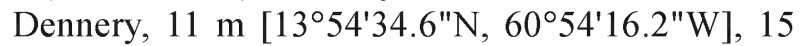
(TTU 109929-43). Laborie: $1.25 \mathrm{~km} \mathrm{~N}, 0.75 \mathrm{~km}$

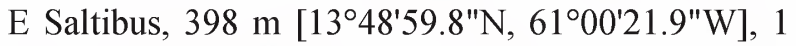
(TTU 111455). Micoud: Canelles River, $1.5 \mathrm{~km} \mathrm{~S}$

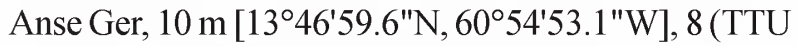
109948-55); Quilesse Forest Reserve, 2.5 km N, 8 $\mathrm{km}$ W Micoud, $283 \mathrm{~m}$ [1350'23.1"N, 6058'25.8"W], 1 (TTU 109947); Troumassee River, 1.3 km W Mi-

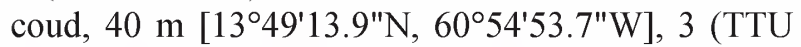
109944-46). Praslin: Mamiku River, 1.1 km N, 0.2

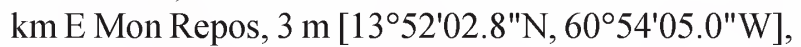
3 (TTU 109956-58); Raillon Negres, 1.2 km N, 2.3 km
W Mon Repos, 255 m [135'ㄹ․ㄹ"N, 6056'09.6"W], 1 (TTU 109959). Soufrière: Diamond Botanical Garden, Diamond, $47 \mathrm{~m}$ [1351'08.7"N, 61 $\left.{ }^{\circ} 02^{\prime} 57.5^{\prime \prime} \mathrm{W}\right]$, 4 (TTU 111456-59); Edmund Forest Reserve, 0.7 km $\mathrm{N}, 1.5 \mathrm{~km}$ E Fond St. Jacques, $550 \mathrm{~m}\left[13^{\circ} 50^{\prime} 27.9^{\prime \prime N}\right.$, 6059'47.6"W], 4 (TTU 109960-63). Vieux Fort: Black Bay, $2.5 \mathrm{mi} W$ Vieux Fort, $100 \mathrm{~m}\left[13^{\circ} 44^{\prime} 36.0^{\prime \prime} \mathrm{N}\right.$, $\left.60^{\circ} 58^{\prime} 55.5^{\prime \prime} \mathrm{W}\right], 1$ (NMNH 514481). No Specific Quarter: no specific locality, 1 (NMNH 110924).

Additional records (Clarke 2009, unless otherwise noted).- Anse La Raye: "Anse La Raye" [= Venus Estate] [converted from UTM, 1355'14.7"N, $\left.61^{\circ} 01^{\prime} 12.1^{\prime \prime} \mathrm{W}\right]$. Choiseul: River Dorée [converted from UTM, 134ㄴ $\left.{ }^{\circ} 05.1^{\prime \prime} \mathrm{N}, 61^{\circ} 01^{\prime} 54.6^{\prime \prime} \mathrm{W}\right]$. Soufrière: Anse Chastanet [converted from UTM, $13^{\circ} 52^{\prime} 00.9^{\prime \prime} \mathrm{N}$, $\left.61^{\circ} 04^{\prime} 10.3^{\prime \prime} W\right]$. No Specific Quarter: no specific locality (Dobson 1878; Allen 1908, 1911; Miller 1913b).

Specimens captured/released (133).-Dauphin:

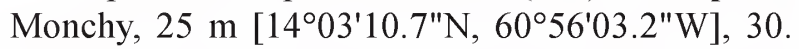
Dennery: Dennery River, $0.25 \mathrm{~km} \mathrm{~S}, 2 \mathrm{~km}$ W Dennery, $11 \mathrm{~m}$ [135ㄴ'34.6"N, 6054'16.2"W], 55; Au Leon Peak, $1 \mathrm{~km} \mathrm{~N}, 1.75 \mathrm{~km}$ E La Ressource, $319 \mathrm{~m}$ [135' $14.4^{\prime \prime} \mathrm{N}$, $60^{\circ} 54^{\prime} 07.1^{\prime \prime W]}$, 7. Laborie: $1.25 \mathrm{~km} \mathrm{~N}, 0.75 \mathrm{~km} \mathrm{E}$

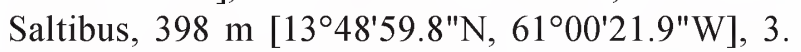
Micoud: Quilesse Forest Reserve, $2.5 \mathrm{~km} \mathrm{~N}, 8 \mathrm{~km} \mathrm{~W}$

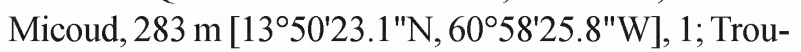

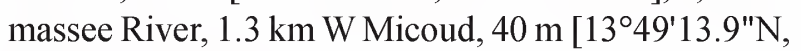
$60^{\circ} 54$ '53.7"W] 37.

Acoustic records.-Clarke (2009) recorded this species at seven of his 16 field sites: Anse La Raye: Anse La Raye; Millet Forest. Castries: Union Trail. Choiseul: River Doree. Dauphin: Sorcière River. Soufrière: Anse Chastanet; Edmund Forest.

Commonly referred to as the "house bat," this bat was widely distributed on the Lesser Antillean islands where historically several scientific names have been used for its populations. Lindsey and Ammerman (2016) included three of our specimens from St. Lucia in their analysis of mitochondrial cytochrome- $b$ gene variation from throughout the geographic range of $M$. molossus. They found that the St. Lucia specimens clustered in a large polytomy including material from Puerto Rico, Lesser Antilles, Guyana, Suriname, Bolivia, and eastern Ecuador. Genetic divergence values 
$(1.2 \%)$ were low within this cluster. This was one of three lineages recovered in their analysis, with the other two consisting of individuals from western Ecuador and from Brazil and Central America. The geographic area of the samples clustered in the large polytomy included the Lesser Antilles where Husson (1962) restricted the type locality of M. molossus to Martinique. This led us to agree with Dolan (1989) and Lindsey and Ammerman (2016) in applying the name M. m. molossus to this species on St. Lucia.

The results of an analysis of secondary sexual variation in the length of forearm and seven cranial measurements of eight male and seven female Molossus are presented in Table 1. Males averaged larger in all measurements, being significantly larger at the $P \leq 0.01$ level for greatest length of skull, zygomatic breadth, and breadth across upper molars and at $P \leq 0.05$ level for length of maxillary toothrow.

Our surveys underestimate the contribution of Molossus to the local bat fauna because it flies higher than our nets usually reach. Our samples were all netted in open flyways or over water where the bats were foraging and attempting to drink. This species can be distinguished by its high, rapid flight in the early evening when some birds were still active. This commensal bat was often abundant over residential areas and adjacent agricultural lands. Clarke (2009) found five day roosts of this species and "All were in abandoned or unoccupied buildings within wet forest." We observed these bats in the walls and ceilings of buildings at all elevations (Fig. 13).

On the central east coast of the island, we placed four mist nets across the Dennery River on the night of 3 August 2008 with the hope of capturing Noctilio. This shallow river was about $10 \mathrm{~m}$ wide with riffles in some areas and small ponds in others. There was a well-developed riparian forest on both sides of the river, beyond that were buildings and small garden/ agricultural plots. The original flora of the area was undoubtedly dry lowland scrub woodland but most of this had been removed. We were unsuccessful in capturing Noctilio; however, we caught four species, with Molossus accounting for $71 \%$ of captures (70). Certainly, these bats were using the river as a water source as they exited from their day roosts, but it also served

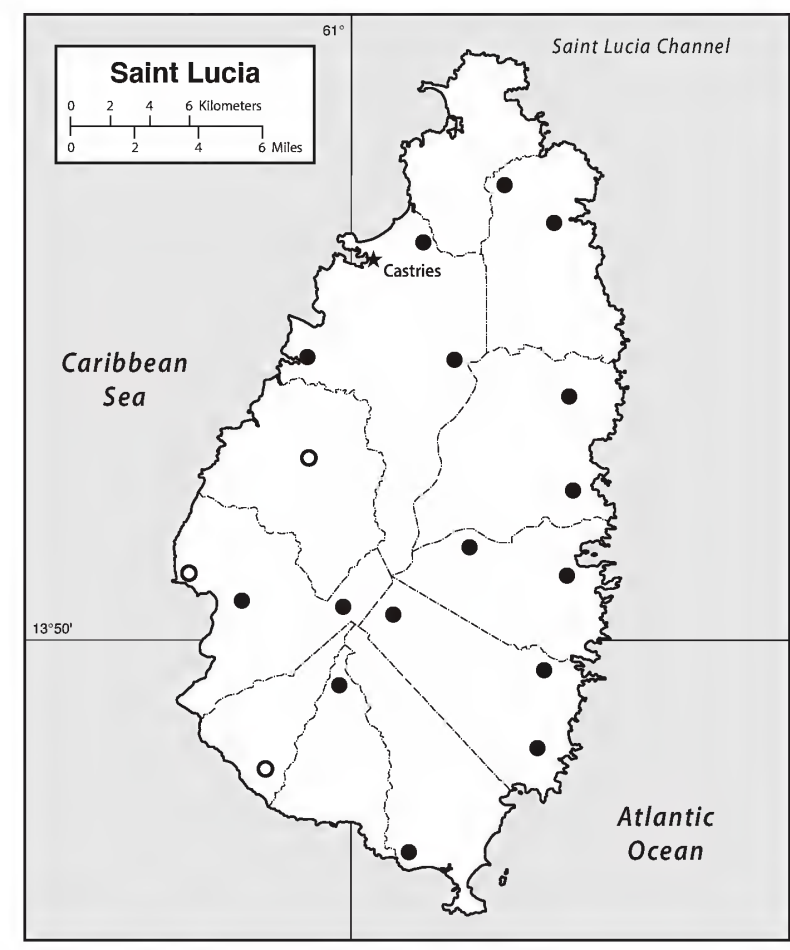

Figure 13. Map of the geographic distribution of Molossus molossus on the Lesser Antillean island of St. Lucia. Symbols include: closed circles represent specimens examined and open circles represent literature records. The closed circle for the record of Molossus molossus from Castries has been omitted because its position has been taken by the star marking the capital city.

as an open flyway in which emergent insects provided a ready food source for these bats. The other three species captured were M. plethodon (1), A.jamaicensis $\times$ schwartzi (27), and T. brasiliensis (1), making this fauna similar to the one from Monchy discussed next.

On the night of 13 March 2009, we netted 34 Molossus at Monchy, our northernmost collecting site on St. Lucia. This was also the driest part of the island where lowland scrub woodland probably prevailed prior to colonization but building development and agriculture had heavily impacted it. Five nets were placed adjacent to the road into the village of Monchy, over a small stream, and across a small access road. This road lay between a small bog with semiaquatic vegetation and a freshly ploughed field. Nearby, there was a small plantation of bananas, a few mango trees, 
and a small chicken raising facility. Three other species were netted at this location: two frugivores $-B$. cavernarum (1) and A. jamaicensis $\times$ schwartzi (39) - and one insectivore- $T$. brasiliensis (1).

The Diamond Botanical Garden was located a short distance inland from the town of Soufrière, up against the leeward slope of the Qualibou Depression. This deep valley would presumably provide some protection from tropical storms. Historically, the Diamond Estate raised limes, cocoa, and coconuts. The botanical garden was established on this site in 1983 and contains many tropical flowering plants and other ornamental plants that are flanked by several large trees that were part of the original forest in the area. From the Diamond Falls at the upper end of the garden, a warm stream runs through the area, eventually draining into the Soufrière River just below the gardens. We set five nets in the garden and one across the stream. We netted eight Molossus and three species of fruit-eating bats $-B$. cavernarum (2), A. jamaicensis $\times$ schwartzi (38), and S. paulsoni (1).

Our study site northeast of Saltibus (Fig. 14) was along a steep ridge $(398 \mathrm{~m}$ ) north of the lowland areas at the southwestern part of the island. The area was dominated by a plantation of Caribbean pines, but tree ferns and pepper plants were located in adjacent disturbed areas. Several inactive farm plots were located below this site where we saw scattered mango and

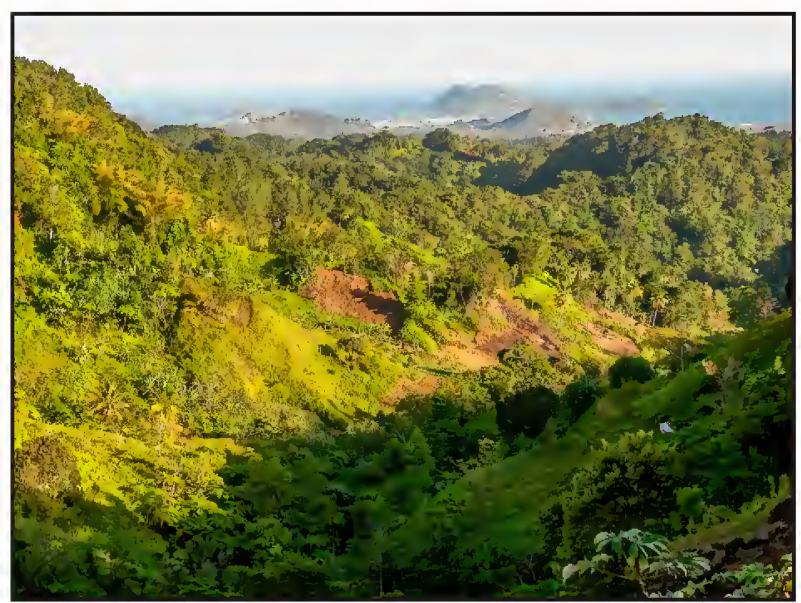

Figure 14. Photograph looking to the south from our field site north and east of Saltibus. The Caribbean Sea can be seen in the far background. Four individuals of Molossus molossus were captured at this site. breadfruit trees. On the evening of 15 March 2009, we netted in mist and light drizzle $\left(23^{\circ} \mathrm{C}\right)$. We set five nets in the plantation and across the access road in which we captured four Molossus along with P. davyi (3), B. cavernarum (2), M. plethodon (6), A. jamaicensis $\times$ schwartzi (3), and S. paulsoni (2).

Between 14 and 17 March 2009, we netted 39 Molossus of which 27 were females and 12 males. None of the females evinced gross reproductive activity. Five of the males were scrotal, two having testes lengths of 4 , whereas seven males had testes in a nonscrotal position with one having a testis length of 2 . All 10 females taken 16-18 June 2007 were pregnant with embryos that averaged 19.3 (10-24) in crown-rump length. The single non-scrotal male taken during that period had testes measuring 4 in length. Between 30 July and 4 August 2008, 90 Molossus were examined for reproductive condition of which 71 were females and 19 were males. The reproductive status of the females was as follows: 55 were lactating; six were lactating and each of which carried a single embryo with a mean crown-rump length of 7.3 (5-10); six were pregnant but were not lactating; and four revealed no gross reproductive activity. Three of the males had testes in an inguinal position. The remaining 16 males were scrotal of which 15 had an average testes length of 4.9 (2-6). A single male taken on 26 August 1967 had testes that measured 3 .

Genoways et al. (2005) concluded that $M$. molossus on Jamaica displayed aseasonal polyestry with some individuals involved in reproductive activity throughout most of the year. However, females taken in mid-March in 2009, on St. Lucia revealed no reproductive activity. This may be due to the fact that February and March are the driest months of the year. Genoways et al. (2001) did not take any pregnant female M. molossus in March on Dominica, but by April 1, three of 10 females were pregnant and three other pregnant females were taken later that month. On Barbados, four non-pregnant $M$. molossus were taken in mid-April, coincident with the netting of juveniles, indicating that parturition had occurred during the previous months. As we view these data from the Antilles, these bats appear to breed at various times during the year but will become quiescent when local conditions are not favorable. 
Weights of 26 non-pregnant female bats taken on St. Lucia between 14 and 17 March averaged 12.0 (11.0-13.0), whereas five scrotal males and seven with testes in non-scrotal had mean weights, respectively, of 14.5 (13.1-17.1) and 13.9 (12.4-15.8). Between 16 and 18 June, 10 pregnant females had a mean body weight of 15.4 (13.4-16.9), while a non-scrotal male from this time weighed 14.7. Fourteen lactating Molossus taken between 30 July and 4 August had a mean weight of $14.3(12.3-15.1)$, whereas six females that were both lactating and pregnant weighed an average of 15.6 (14.6-16.6). Fifteen scrotal males taken during this latter period weighed an average of 17.1 (15.6-18.3). On average, male Molossus weigh more than females, although pregnant females do approach the weights of males.

No gross abnormalities were observed in any of these bats; however, one female exhibited a welldefined white spot on the left ear (Dennery River, 3 August 2008).

\section{Tadarida brasiliensis antillularum (Miller, 1902) Brazilian Free-tailed Bat}

Specimens examined (47).-Castries: Castries, 2 (KU 9663, 9666). Dauphin: Ruins of Marquis Estate, $1.6 \mathrm{~km} \mathrm{~N}, 0.8 \mathrm{~km}$ E Boguis, $25 \mathrm{~m}\left[14^{\circ} 01^{\prime} 35.2^{\prime \prime} \mathrm{N}\right.$, 6054'40.6"W], 12 (TTU 110619-30); Monchy, 25 $\mathrm{m}\left[14^{\circ} 03^{\prime} 10.7^{\prime \prime} \mathrm{N}, 60^{\circ} 56^{\prime} 03.2^{\prime \prime} \mathrm{W}\right], 1$ (TTU 113333). Dennery: Dennery River, $0.25 \mathrm{~km} \mathrm{~S}, 2 \mathrm{~km}$ W Dennery,

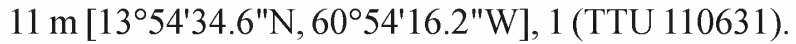
Gros Islet: Union Agriculture Station, $100 \mathrm{ft}, 8$ (KU 110248-55). Micoud: Troumassee River, $1.3 \mathrm{~km} \mathrm{~W}$

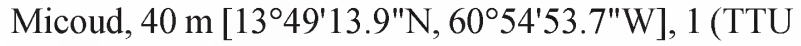
110632). Praslin: Fox Grove Inn, $1.1 \mathrm{~km} \mathrm{~N}, 0.2 \mathrm{~km}$ W Mon Repos, 52 m [1351'47.0"N, 605 $54^{\prime} 22.8^{\prime \prime} \mathrm{W}$, 4 (TTU 110633-36). Soufrière: Edmund Forest Reserve, $0.7 \mathrm{~km} \mathrm{~N}, 1.5 \mathrm{~km}$ E Fond St. Jacques, $550 \mathrm{~m}$ [1350'27.9"N, 6059'47.6"W], 7 (TTU 110637-43). No Specific Quarter: no specific locality, 11 (NMNH 110906-16).

Additional records.-Choiseul: River Dorée [converted from UTM, 1346 $\left.05.1^{\prime \prime} \mathrm{N}, 61^{\circ} 01^{\prime} 54.6^{\prime \prime} \mathrm{W}\right]$ (Clarke 2009). No Specific Quarter: no specific locality (Miller 1902; Allen 1911; Shamel 1931; Jones and Phillips 1970).
Specimens captured/released (135).-Dauphin: Ruins of Marquis Estate, $1.6 \mathrm{~km} \mathrm{~N}, 0.8 \mathrm{~km}$ E Boguis, $25 \mathrm{~m}\left[14^{\circ} 01^{\prime} 35.2^{\prime \prime} \mathrm{N}, 60^{\circ} 54^{\prime} 40.6^{\prime \prime} \mathrm{W}\right], 135$.

Acoustic records.-Clarke (2009) recorded this species at two of his 16 field sites: Castries: Union Trail. Dauphin: Marquis Estate ruins.

Based on holotype material from Roseau, Dominica, Tadarida brasiliensis in the Lesser Antilles were thought to be smaller than those in the Greater Antilles and subsequently named Nyctinomus antillularum [=Tadarida brasiliensis antillularum] by Miller (1902). He assigned specimens from Montserrat, St. Kitts, St. Lucia, and Tobago to this new taxon. In his revision of the genus Tadarida, Shamel (1931) treated this species under the name $T$. antillularum and added material from Antigua, Guadeloupe, and Puerto Rico to this monotypic species. Schwartz (1955) reduced this species to subspecific rank within the widespread mainland species Tadarida brasiliensis. Although several closely related subspecies of this free-tailed bat can be found in the Antilles, T. b. antillularum is distributed from Puerto Rico southward to St. Vincent (Schwartz 1955) and is presently unknown from Barbados (Genoways et al. 2011), Grenadines (Genoways et al. 2010), and Grenada (Genoways et al. 1998). As indicated by Timm and Genoways (2003), there are subtle morphological variations among Antillean populations that separate the subspecies $T . b$. antillularum and $T . b$. constanzae (from Hispaniola).

Owen et al. (1990) raised the possibility that Antillean populations of $T$. brasiliensis were more closely related to T. b. cynocephala of the southeastern United States than to T. b. mexicana of the southwestern United States and Mexico. They studied these relationships using morphometrics and protein electrophoresis, especially of the esterase-2 locus. They found that $T$. b. cynocephala and $T$. b. mexicana could represent separate species because of the larger cranial size of $T$. b. cynocephala and different alleles for the easterase- 2 locus. If their supposition is correct, it would represent a unique invasion of the West Indies from the north (Rodríguez-Durán and Kunz 2001). There is great need for a modern molecular phylogenetic analysis of the entire Tadarida brasiliensis complex including those in the Caribbean basin. 
Our analyses for secondary sexual variation of the length of forearm and seven cranial measurements of 10 male and 15 female Tadarida (Table 1) revealed that only the greatest length of skull in males was significantly larger $(P \leq 0.01)$. In addition, males averaged larger in condylobasal length, whereas females averaged larger in three measurements - length of forearm, postorbital constriction, and mastoid breadth.

The Fox Grove Inn was a small resort above the Mamiku River on the Atlantic Coast of St. Lucia where we made our headquarters during our three surveys (Fig. 15). This area was a sugar plantation during the colonial period, but now produces a variety of fruits, including bananas. On the night of 29 July 2008, we placed four mist nets among the ornamental plantings, between buildings, and one across the $10 \mathrm{~m}$ by $30 \mathrm{~m}$

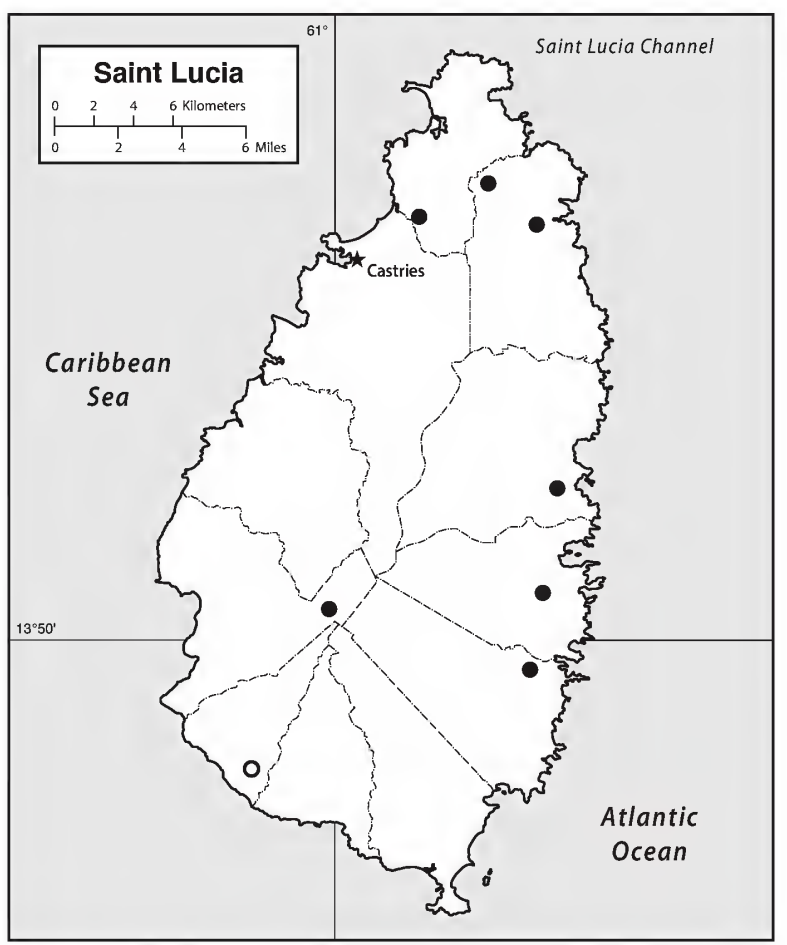

Figure 15. Map of the geographic distribution of Tadarida brasiliensis on the Lesser Antillean island of St. Lucia. Symbols include: closed circles represent specimens examined and the open circle represents a literature record. The closed circle for the record of Tadarida brasiliensis from Castries has been omitted because its position has been taken by the star marking the capital city. resort swimming pool. Over the course of the evening, we captured four of these free-tailed bats in this net located about $0.5 \mathrm{~m}$ above the surface of the water. These bats arrived after $1800 \mathrm{hr}$ and probably were coming to the pool to drink. Other nets at this site captured $M$. plethodon (1) and A. jamaicensis $\times$ schwartzi (18).

In the late afternoon and evening of 17 June 2007, we collected bats in and around the ruins of Marquis Estate in the Quarter of Dauphin. This area was dominated by abandoned agricultural lands that bordered the Marquis River. Four nets were set to take advantage of mango trees, bananas, scrub-forest edge, and flyways. Three large nets ( $18 \mathrm{~m}$ and two $12 \mathrm{~m}$ ) were stretched across the Marquis River in the hopes of catching Noctilio. One of the ruined estate buildings housed a breeding colony of more than 1,000 of these free-tailed bats. We netted 147 individuals from this colony, with 92 being females and 55 males. Eighty-seven of these females were pregnant, carrying a single embryo of which six averaged $15.0(14-18)$ in crown-rump length. Six scrotal males had testes with a mean length of 2.5 (2-3). Three females were netted between 31 July and 4 August 2008, two of which were lactating and the third was pregnant and lactating, with the embryo measuring 22 in crown-rump length. The 10 males collected between 30 July and 2 August 2008 were all judged to have testes in an inguinal position, with seven having a mean testes length of 2.3 (2-3). On 26 August 1967, seven female Tadarida were obtained on St. Lucia of which six were lactating and one exhibited no gross reproductive activity. Mainland populations of this species are monoestrous producing a single young in May-June and fledging them generally by early August (LaVal 1973; Wilkins 1989). Although this island population may be following a similar pattern, parturition and lactation extend through August. Either the island's population reproductive cycle was not as highly synchronous as it was on mainland or there was a postpartum estrus leading to a second period of reproduction.

Six pregnant free-tailed bats captured in mid-June had a mean weight of $9.6(9.0-10.0)$, whereas seven adult males from this time had a mean weight of 7.7 (6.9-8.3). A pregnant and lactating female taken on 30 July weighed 11.7 , whereas two lactating females taken between 31 July and 4 August weighed much 
less at 9.5 and 9.4, respectively. Nine males netted in late July and early August had an average weight of
9.8 (8.5-11.4), which was more than 2 grams heavier than the males in June.

\section{Discussion}

Achieving a better understanding of the ecological and evolutionary mechanisms responsible for patterns of faunal distribution along island archipelagos is a long-standing goal of biogeographical research (Patino et al. 2017). Dispersal of species along island chains is influenced strongly by distances between islands (Koopman 1976; Genoways 1998; Whittaker 1998), regional storm patterns, and species vagility (Paine 1977; Waters 2011; Steinbauer et al. 2016; Steinbauer 2017). But a persistent and mostly unresolved question in island biogeography is the extent to which insular patterns of animal movement and distribution are due to either stochastic (storm transport-Connor and Simberloff 1978, 1979; Simberloff 1978, 1980; Connor and McCoy 1979; Brown 1986; Fleming and Murray 2009; Genoways et al. 2010) or deterministic factors (that is, dispersal behavior-Lawlor 1986; Lomolino 1986; Patterson and Atmar 1986). Despite the wealth of survey data, voluntary movement patterns of bats throughout the Lesser Antilles are effectively unknown and would be certainly species-specific (Carstens et al. 2004; P. Larsen et al. 2010; R. Larsen et al. 2012, 2017). If stochastic rather than deterministic mechanisms drive the movement of bats among islands, the distributional data should be relatively consistent among species. For St. Lucia, this is clearly not the case.

The known fauna of St. Lucia consists of only nine species: one noctilionid ( $N$. leporinus), one mormoopid (P. davyi), five phyllostomids (M. plethodon, A. jamaicensis $\times$ schwartzi, B. cavernarum, A. nichollsi, and S. paulsoni), and two molossids (M. molossus and $T$. brasiliensis). This fauna is smaller than those reported for the other islands in the Lesser Antillean Faunal Core-Montserrat, 10 species; Guadeloupe, 12; Dominica, 12; Martinique, 11; and St. Vincent, 12 (Table 2).

To gain a broader understanding of the role of natural dispersal in the development of the Lesser Antillean bat faunas, we have constructed a tentative framework for such events. Using this, we have analyzed the structure of the St. Lucian bat fauna to learn if there is a reason unique to St. Lucia for its reduced fauna. We are well aware that additional survey work on the island could overturn this view; however, we believe that this framework and analysis should be useful in understanding the formation of the bat faunas along the Lesser Antillean archipelago.

\section{Framework for Natural Dispersal}

Scientists studying human-mediated invasion biology of plants and animals have worked to develop a framework for how this process would proceed (Williamson and Fitter 1996; Richardson et al. 2000; Britton-Simmons and Abbott 2008; Valéry et al. 2008; Blackburn et al. 2011). Because these efforts were centered on human-induced invasions, their framework is not directly applicable to natural dispersal events, but some of the elements are similar and can be used as guideposts to develop a framework for natural dispersal. Invasions are discussed in terms of barriers to be overcome and the stages or events that allow the species to succeed or fail to move forward with dispersal (Blackburn et al. 2011). In our discussion, we use the term propagule as used by Simberloff (2009; see also Lockwood et al. 2005, 2009) meaning: "a group of individuals arriving in a place." Because the natural dispersal events of interest to our research involve overwater dispersal by volant species, we will develop the framework around these events as they may occur in relation to the islands of the Caribbean.

Philopatry.-In our theoretical natural dispersal scenario, the first barrier to be overcome would be philopatry. This is the tendency of bats as well as other organisms to remain close to their place of birth. This is simply because they are familiar with the local fruitripening sequence, where concentrations of insects may occur, where appropriate roost sites are to be found, and the presence or location of conspecifics. Resources beyond this area are unknown and therefore pose a risk. Therefore, displacement and/or dispersal of these animals requires either internal (sex-specific dispersal, conspecific competition, etc.) or external factors that 
Table 2. Species distribution matrix for the bats of Lesser Antilles. Refer to key below the table for more information.

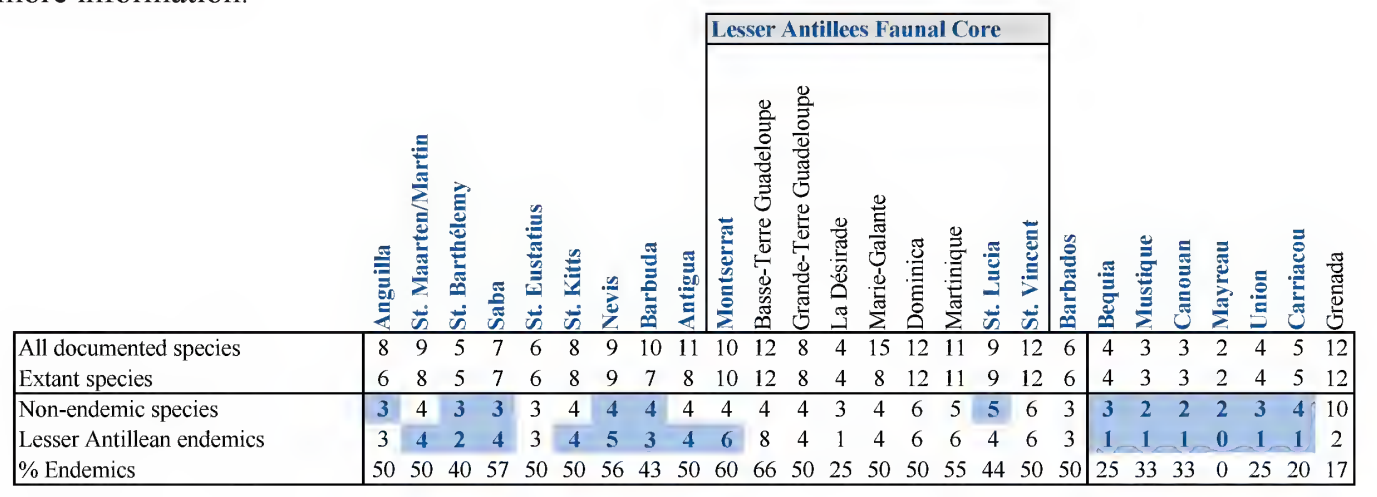

Carnivore

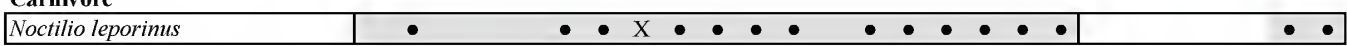
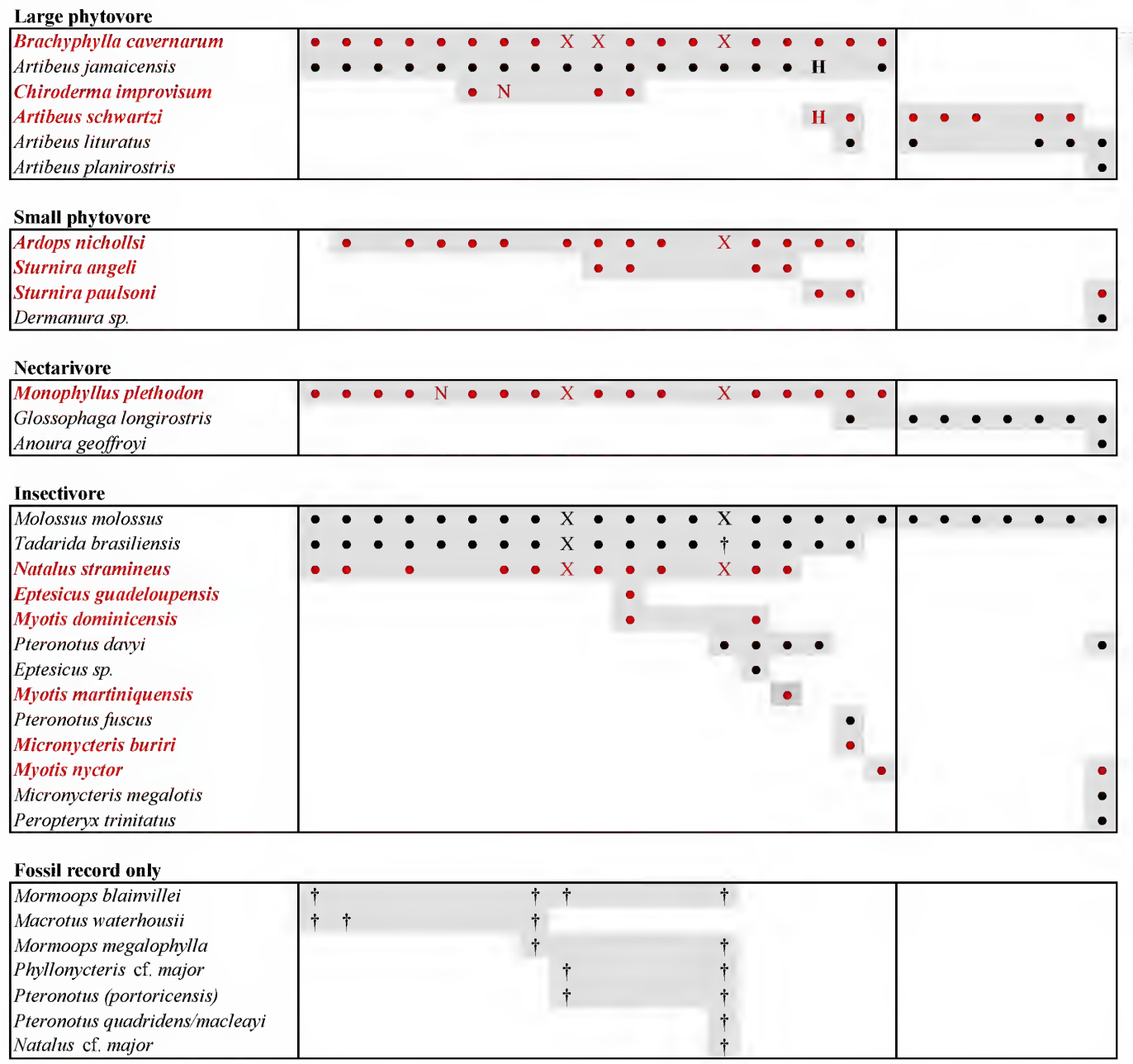

Data: Pedersen et al. 2013, Stoetzel et al. 2016, Pedersen et al. 2018

Blue text - Island surveyed by authors 1993-2011

Blue \# - Effort added at least one species to this category

Red - Lesser Antillean endemic species

Within guild, taxa are arranged by distribution, north $>$ south

The vertical line between Barbados and Bequia represents Koopman's Line.

$\mathrm{H}$ - A. jamaicensis x schwartzi hybrid (see text) Dot - Indicates published record

$\mathrm{N}$ - Unpublished record

$X$ - Both extant \& fossil records

$\uparrow$ - Fossil only

Empty box - species that is 'missing' on SLU 
disrupt the environment or destroy resources - both referred to as "upheavals" by Waters (2011). Common upheavals in the Caribbean would be hurricanes, tropical storms, flooding, droughts, landslides, earthquakes, volcanic eruptions and their associated pyroclastic flows, changing sea levels, and habitat destruction associated with human occupation (Pedersen et al. 2012).

Dispersal mechanisms.-Once oceanic island bats have been motivated/forced to leave their home island or the mainland, the next barrier to surmount would be the overwater distance between islands. In a study of long-distance dispersal to oceanic islands in the Pacific, Gillespie et al. (2012) described the forces that move organisms as "vectors"- "Key elements contributing to the effectiveness of these vectors as dispersal agents are their sustained velocity and directionality, together with their capacity to pick up and transport propagules" (Simberloff 2009; see also Lockwood et al. 2005, 2009). The most relevant of these vectors to our discussion is the dispersal of bats among islands that is facilitated by prevailing winds or tropical storms. Contemporary storms in the Caribbean follow a general pattern-forming over the Atlantic Ocean, the storms move from east to west; at some point the storm's track will make a turn to the north or northwest; finally, as the storms weaken they will turn to the right (east); if the storms hold together they eventually disintegrate over the North Atlantic. The paleoclimatological data demonstrates that there are several variations on this generalized track, but all favor the general movement of bats from northeastern South America up through the Lesser Antillean chain.

Although the trade winds are of lower velocity than the major storms, Gillespie et al. (2012) believed they could be effective in moving a propagule over short distances. At the present time, the trade winds blow steadily ( 18 to $20 \mathrm{~km} / \mathrm{hr}$ ) through the Lesser Antilles toward the equator, from the northeast. These winds may assist the southward dispersal among some islands by such species as A. jamaicensis, $N$. stramineus, and T. brasiliensis. In particular, the available genetic data from $A$. jamaicensis supports this dispersal pattern and indicates a recent (less than 15,000 years ago) southward expansion by this species throughout the Lesser Antilles (P. Larsen et al. 2010). Clearly, some species of bats are stronger fliers than others. Given what we know about foraging distances on individual islands (Pedersen et al. 2006, unpublished data collected on Montserrat), the distances between many islands could be crossed in a normal evening's flight by several species, e.g., $N$. leporinus, B. cavernarum, A. jamaicensis, A. schwartzi, M. molossus, and T. brasiliensis. This is particularly true in the northern Lesser Antilles where the distances between islands would have been even less during the Last Glacial Maximum.

Arrival and Survival.- The next barrier for dispersing bats to overcome would be survival in their new surroundings (Blackburn et al. 2011). Translocated bats may arrive in poor health and it is critical that they find food and shelter almost immediately. Some species apparently have the capability of resting on small, inhospitable islands for a few days before seeking better habitat on other islands. This is what we believe occurred (Genoways et al. 2010) following extensive damage from Hurricane Ivan to the forests on Grenada, resulting in a small group of A. lituratus appearing on the island of Mayreau for about a week before disappearing.

Translocated bats would also come into contact and competition with the incumbent species for resources. This competition could be formidable if this island's habitats and resources had been severely damaged by the same storm that displaced the bats from their previous home. For many species of bats, this initial survival may be the most critical stage of dispersal (Gannon and Willig 1994; Pedersen et al. 1996, 2010, 2013; Jones et al. 2001; Presley et al. 2008; Willig et al. 2010). Jeschke and Strayer (2005), studying humanmediated dispersal of vertebrates, found that the lowest success rate occurred in this initial step, rather than in any of the later stages. Their results showed successful introduction rates of 2.0 to $6.3 \%$ for terrestrial mammals, but without the aid of humans, the introduction rate for natural dispersal would be expected to be less than this.

Colonization.-The next barrier facing displaced bats would be adaptation to their new habitat. Islands with higher elevations have a wider range of habitats and are therefore more likely to provide a match to the propagule's native habitat (Steinbauer 2017), that is, "Successful colonization and establishment 
are more likely in environments that approximately match the source environment" (Gillespie et al. 2012). Vermeji (1996; see also Colautti et al. 2006) opined that "weedy" or opportunistic species would be better dispersers because of their broader habitat tolerance, which would be particularly true in the disturbance prone Lesser Antillean islands-A. jamaicensis and $M$. molossus being the bat exemplars of this. For more specialized species of bat, they will need to identify year-around food supplies, day roosts, and night roosts large enough to serve as maternity/bachelor colonies if necessary, and a sustaining range of microclimates. It is possible that adaptation to these factors happens quickly, as discussed in some detail elsewhere (Lucek et al. 2012; Kwiecinski et al. 2018).

One factor in survival and successful colonization may be the sequence in which species arrive on an island because "only those species differing sufficiently from species already present are likely to become established" (Vermeji 1996). This phenomenon was termed the "priority effect" by Steinbauer (2017) and the "progression rule" by Waters (2011). This "priority effect" can be offset by propagule pressure - the number of individuals arriving (Williamson and Fitter 1996; Blackburn et al. 2011). Simberloff (2009) showed that as the propagule size increases, the likelihood of establishment increased and the number of times that propagules arrive diminishes impacts of environmental stochasticity. In the long term, a failure of a species to survive and ultimately colonize an island, in the first instance of dispersal, does not predict what will happen in subsequent events.

Reproduction.-The final barrier to the successful dispersal of bats to islands would be sustained reproduction. The idea of the lone pregnant female being a successful propagule must be abandoned in favor of identifying what is the minimum viable propagule for each species of bat in the system. Bats have low reproductive rates. On St. Lucia, P. davyi, B. cavernarum, and $T$. brasiliensis produce a single young per year and the other species may produce two young per year. Beyond replacing the original propagule, the process of generating a sustainable population can take several years with these low reproductive rates.

Lockwood et al. (2005) believed that low levels of genetic variation in small propagules will decrease the probability of non-native population establishment. Certainly, the depression of genetic variability in the original propagule can negatively impact reproductive success as inbreeding progresses. However, Presley and Willig (2010) argued that many species of bats in this archipelago exist as a metacommunity, inferring that dispersal amongst islands may not be as much of an obstacle as discussed herein. Indeed, the highly vagile molossid, T. brasiliensis, exhibits a considerable amount of community structure throughout the Bahamas (Speer et al. 2017). This suggests that body size and vagility are poor predictors of connectivity in this system. Such connectivity would overcome the potential reduced genetic variability in a propagule, via the steady exchange of new genetic material between fragmented patches which could promote long-term species survival (Trakhtenbrot et al. 2005).

Hypotheses regarding population-level genetic variation can easily be tested, however nearly all genetic data that have been generated from the bats of the Lesser Antilles has been from particular mitochondrial genes (e.g., cytochrome- $b$ ). Although the nucleotide variation observed in these datasets is appropriate for resolving species or subspecies-level taxonomy, it is not necessarily appropriate for resolving population-level questions of genetic variation. Therefore, we recommend additional studies that utilize appropriate genetic approaches with the resolving power for testing hypotheses regarding population-level genetic variation.

If dispersing species of bats fail to accomplish any of the stages in our proposed framework, the species will be locally extirpated. Jones et al. (2003) studying the causes of extinctions in bats found that the greatest risk factor was associated with small geographic ranges. Other risk factors included island endemicity, low birth rates, and low wing aspect ratios. These factors clearly indicate that it is island populations of bats that are most at risk of extinction, relative to mainland species of bats. There is an adequate fossil record for bats in the Greater Antilles and a developing record for the Lesser Antilles, but these come from the northern Limestone Caribbees (Pregill et al. 1994; Orihuela and Tejedor 2015; Boudadi-Maligne et al. 2016; Stoetzel et al. 2016) and little or no fossil record is available for bats in the southern Lesser Antilles including St. Lucia. Without a fossil record, we cannot determine which species have failed in natural dispersal events 
on the islands, but our data on the modern fauna will allow an assessment of the St. Lucia fauna and its place in the Lesser Antilles.

\section{The "Missing" Species of Bats of St. Lucia}

The known bat fauna of St. Lucia consists of nine species but there are a number of species that are noticeably absent-a) Pteronotus fuscus, Micronycteris buriri, Glossophaga longirostris, and Artibeus lituratus, each known from the adjacent island of St. Vincent to the south; b) Myotis martiniquensis and Natalus stramineus, which are found immediately to the north on Martinique; and c) Myotis nyctor to the east on Barbados (Table 2). These seven "missing" species represent six disparate taxonomic groups: Natalidae, Vespertilionidae, Mormoopidae, and three phyllostomatid subfamilies - Glossophaginae, Phyllostominae, and Stenodermatinae. With the exception of $A$. lituratus, these are small, cave or cavity roosting, presumably monoestrous bats (except Glossophaga), which feed primarily on insects, or will do so seasonally (that is, Glossophaga).

Natalus stramineus: $N$. stramineus is a Lesser Antillean endemic species known from most islands between Anguilla and Martinique but is absent from islands to the south of Martinique. This is in keeping with Genoways et al. (2005), who hypothesized that natalids originated and radiated in the Antilles, with $N$. stramineus appearing in the Lesser Antilles. Despite being small-bodied and seemingly delicate bats, the natalids evolved in disturbance prone environments and $N$. stramineus is found scattered throughout the northern Lesser Antilles, often in rather large numbers (Pedersen et al. 2007). This bat has specific roost requirements (Tejedor 2006) and the lack of suitable roost sites (moist, dark caves) may be partly responsible for the lack of successful colonization of St. Lucia by this species.

Myotis martiniquensis: Large numbers of this single-island endemic have been netted on Martinique (192 of 1859 total bat captures in foraging and commuting habitat, $10.3 \%$ ) (Catzefl is et al., personal communication), suggesting that extant propagule pressure is not the reason for the lack of movement southward to St. Lucia (Lockwood et al. 2005). Its wide-ranging choice of roosts - caves, rock crevices, tree cavities, and human structures - would improve its chances of surviving in the aftermath of tropical storms or would increase its chances of successful colonization of a new island through storm transport. R. Larsen et al. (2012) presented data indicating that members of the genus Myotis invaded the Lesser Antilles at least twice. The ancestor of M. dominicensis and M. martiniquensis entering the islands in the Pliocene, 4 to 5 million years ago. It is unknown whether or not members of this genus ever successfully colonized St. Lucia or if additional fieldwork will identify Myotis on the island.

Myotis nyctor: This species is only known from Barbados and Grenada, presumably colonizing the Caribbean from South America, this being based on close genetic and morphological affinities (R. Larsen et al. 2012). On Barbados, this species was common in the protective rocky limestone walls of numerous gullies and caves. Elsewhere, appropriate roost sites could be a limiting factor for this relatively delicate forest bat. R. Larsen et al. (2012) presented data to indicate that $M$. nyctor represented a second invasion of the Lesser Antilles and probably populated the islands during the Pleistocene and reached Barbados sometime after 700,000 years ago. It is unknown whether or not $M$. nyctor has gone locally extinct on St. Vincent or St. Lucia or if this species ever colonized these islands. Additional fieldwork may or may not identify additional populations of Myotis in the southern Lesser Antilles.

Pteronotus fuscus: This is a large, insectivorous bat, easily capable of moving between St. Vincent and St. Lucia. Indeed, it was caught on the northern tip of St. Vincent a mere $42 \mathrm{~km}$ away. The nearest population of P. fuscus to St. Vincent is on Trinidad and the northern coast of South America indicating that they are capable of covering long distances. This is a cave roosting species, so roost site availability could also be a limiting factor to its colonization of St. Lucia. Pavan and Marroig (2016) placed the divergence of $P$. davyi and $P$. fulvus at about 1.6 million years ago and the divergence among $P$. mesoamericanus, $P$. mexicanus, and $P$. fuscus at about 1.3 million years ago. This could have given $P$. davyi priority in dispersing into the Lesser Antilles. However, the distribution of $P$. davyi extends from Marie Galante southward to Dominica, Martinique, St. Lucia, and Grenada, but it is absent from 
St. Vincent the only island where P. fuscus occurs. This certainly could be an example of the priority effect, with the exclusion based on overlap in prey items or even more probable competition for very limited roost sites on both islands. An anecdotal piece of information indicating a shortage of cave roost sites on St. Lucia was the discovery by Arendt and Anthony (1986) of a large colony of $B$. cavernarum in a cavity in acomat boucan tree. This is a highly unusual day roost site for this cavernicolous species.

Micronycteris buriri: This is relatively rare single-island endemic found on the adjacent island of St. Vincent where it represented only $1 \%$ of all captures $(19 / 1965)$. This cave bat is closely related to the congeneric, M. megalotis, which is equally rare on Grenada (Genoways et al. 1998). As with many other "missing" taxa, the availability of appropriate roost sites may have limited its successful colonization of St. Lucia. Alternatively, given the hypotheses put forth by P. Larsen et al. 2011, it is possible that M. buriri is the result of intense and rapid local adaptation to St. Vincent and has simply not yet successfully colonized St. Lucia to the north.

Glossophaga longirostris: This is a common species of bat on the adjacent island of St. Vincent. This facultative insectivore accounted for $18 \%$ of all captures on St. Vincent (356/1965) - given this relatively large population, its absence on St. Lucia is the most puzzling of all species. It is possible that its absence is due to competition with the incumbent pollinator on St. Lucia-Monophyllus (Waters 2011; Steinbauer 2017) - perhaps a demonstration of the priority effect or progression rule. It should be noted that significant populations of several species of Glossophaga are available for dispersal from source areas in northern South America and Central America. Two species of Glossophaga entered the Antilles from opposite ends$G$. soricina from the west to Jamaica (Genoways et al. 2005) and G. longirostris from the south up to St. Vincent. Only on the islands of Jamaica and St. Vincent do the genera Monophyllus and Glossophaga co-occur.

Artibeus lituratus: This species was rare on St. Vincent with only two specimens taken among the 1965 bats captured during our work there (Kwiecinski et al. 2018). However, these were netted at the northern tip of that island from which St. Lucia was easily seen across the channel. A. lituratus is primarily a tree-roosting species and has often been netted in groves of coconut trees, which are common on the north end of St. Vincent and the adjacent southern shore of St. Lucia. The absence of A. lituratus possibly could be another example of the priority effect with $A$. schwartzi as its competitor. We believe that $A$. schwartzi is a product of reticulate evolution on St. Vincent (P. Larsen et al. 2010) and it approaches the size of A. lituratus (Jones 1978) and they may compete, especially for food resources. The priority effect could account for the low numbers of $A$. lituratus on St. Vincent and its absence from St. Lucia. Alternatively, the genetic data presented by P. Larsen et al. (2013) indicate a very recent expansion event by $A$. lituratus throughout the Neotropics, and therefore this species may simply not had enough time to establish populations in the southern Lesser Antilles.

\section{The Distribution of Bats Throughout the Lesser Antilles}

The Lesser Antillean Faunal Core.-The "Lesser Antillean Faunal Core" refers to the extant bat fauna of the central Lesser Antillean islands-Montserrat to St. Vincent. This fauna is characterized by the presence of ten or more species that includes several endemic taxa. The southern zoogeographic limit of the Lesser Antillean bat fauna is demarcated as Koopman's Line (Genoways et al. 1998, 2010; Kwiecinski et al. 2018) and is located just south of St. Vincent. On islands south of this line, the bat faunas are composed of South American and widespread species of bats. A similar line for avifauna exists between Tobago and Grenada designated as Bond's Line (Lack 1976; Wunderle 1985; but see Ricklefs and Bermingham 2004). This Lesser Antillean bat fauna has two primary sources of colonization-Central America-Greater Antilles and northern South America. Different assemblages of bats from opposite ends of the archipelago should systematically colonize islands. The subsequent boundaries and zones of overlap will vary with the individual species of bat. But without a broad fossil record, we cannot determine the nature of this overlap historically, nor understand why some species failed to disperse more broadly. However, the assemblage of fossil bats on the island of Marie Galante would suggest that these boundaries shift and are influenced by climatic conditions. During 
glacial periods, this assemblage contained several species that are considered to have been derived from the north (Greater Antilles), this alternating with species moving up the chain from the south during interglacial events (Stoetzel et al. 2016).

Plant-visiting bats of South American origin are found on St. Vincent and islands to the south ( $A$. lituratus, A. schwartzi, and G. longirostris), albeit $S$. paulsoni is found on St. Lucia. Those endemic species with origins in the Greater Antilles occur on St. Vincent and islands to the north (B. cavernarum, A. nichollsi, and M. plethodon). The situation with Artibeus is far more complicated and involves reticulated evolution among multiple species of Artibeus converging on St. Lucia and St. Vincent from both northern and southern invasion routes (P. Larsen et al. 2010).

Such feeding guild assignation is also complicated by the fact that several plant-visiting bats are facultative and/or seasonal insectivores: $A$. jamaicensis (Herrera et al. 2001, 2002; Orr et al. 2016), B. cavernarum (Pedersen et al. 1996; Lenoble et al. 2014a), and the two glossophagines, Monophyllus and Glossophaga (Clare et al. 2014). This dietary plasticity is most commonly noted in reproductive females who have an increased demand for nutrients and may also reflect the seasonal availability of preferred forage (Patterson et al. 2003). By itself, such omnivory is not obviously related to species dispersal per se, but it has a strong effect on apparent guild composition and may impact the propagule sequence (Meyer et al. 2015). Certainly, omnivory is an effective adaptation in terms of survival in the aftermath of natural disasters, such as volcanic eruptions and hurricanes (Pedersen et al. 1996, 2012).

There are three species of dedicated insectivorous bats on St. Lucia. To the north, Martinique has five, and St. Vincent to the south has four species of insectivores (Table 2). The apparently depauperate insectivore fauna of St. Lucia poses several questions, including: a) is there something about the physiography or habitat diversity of St. Lucia that could affect its fauna and interfere with species richness in the insectivore guild (Table 3); b) is the propagule pressure too low-is St. Lucia simply located "too far" south for $N$. stramineus and M. martiniquensis, and "too far" north for M. buriri, P. fuscus, and perhaps even M. nyctor, to colonize (Table 2)? If this is the case, St. Lucia may also be an island "too far" north for the phyllostomids, $G$. longirostris and A. lituratus.

Regardless, the bat fauna of St. Lucia is depauperate relative to the neighboring islands. Its species inventory could change with the next expedition to the island, as we have seen with some of our earlier work (Lindsay et al. 2010; Beck et al. 2016). Nevertheless, it can be informative to examine potential reasons as to why only nine species have been taken on the island under conditions and field efforts that have yielded larger numbers of species on other Lesser Antillean islands.

Survey bias, netting effort, and roost surveys.Accurate species inventories for an island are hampered by the inadequacy of ground-based mist netting strategies, something that has been painfully obvious to field biologists who study species-specific responses to mist nets and species-specific ability to avoid mist nets (Francis 1989; Simmons and Voss 1998; Barber et al. 2003; Berry et al. 2004; Lang et al. 2004; R. Larsen et al. 2007; Meyer et al. 2011). This phenomenon was clearly demonstrated by R. Larsen et al. (2007) who found that on average, only $3.2 \%$ of bats passing through a flyway are captured in a mist net.

Caves, rock fissures/over-hangs, and their manmade equivalents (mines, wells, cisterns, abandoned buildings) provide critical refugia for bats during the breeding season and in times of natural disturbance (Gannon and Willig 1994; Pedersen et al. 1996; Rodríguez-Durán 2010). The availability of roosts is thought to be the most critical limiting factor in the successful colonization of islands by bats in the region (Pedersen et al. 2003, 2005, 2006; Genoways et al. 2007a, 2007b, 2007c). The loss of even a single cave roost on a small island, via earthquakes, volcanic activity, or human action can have a disproportional impact on an island's fauna (Pedersen et al. 1996, 2012; Genoways et al. 2007b; Cooke et al. 2017). Dávalos and Russell (2012) attributed the Holocene extinction of bats in the Caribbean to rising sea levels and the flooding of low lying caves. Soto-Centeno and Steadman (2015) disputed this interpretation of the fossil record, yet these data underline the importance of caves and other shelters to bat populations in this region. Unlike our inventory work on other islands in the region 
Table 3. Guild composition and survey efforts. Capture data include only sites located away from known roosts. Data from Catzeflis et al., pers. comm. (Martinique), Kwiecinski et al. 2018 (St. Vincent), and this study (1967, 1987, 2007-2009; St. Lucia). Species classified as follows: Carnivore-Noctilio leporinus; Large fruit bats-Artibeus jamaicensis, A. lituratus, A. schwartzi, Brachyphylla cavernarum; Other fruit bats-Ardops nichollsi, Sturnira angeli, S. paulsoni; Nectarivores—Glossophaga longirostris, Monophyllus plethodon; and Insectivores—Micronycteris buriri, Myotis martiniquensis, Pteronotus davyi, P. fuscus, Natalus stramineus, Tadarida brasiliensis, and Molossus molossus.

\begin{tabular}{|c|c|c|c|}
\hline & Martinique & St. Lucia & St. Vincent \\
\hline \multicolumn{4}{|l|}{ Guild composition } \\
\hline Extant species & 11 & 9 & 12 \\
\hline Lesser Antillean endemics (\%) & $6(55)$ & $4(44)$ & $6(50)$ \\
\hline Carnivore taxa (\%) & $1(9)$ & $1(11)$ & $1(8)$ \\
\hline All fruit bats (\%) & $4(36)$ & $4(44)$ & $5(42)$ \\
\hline Large fruit bats (\%) & $2(18)$ & $2(22)$ & $3(25)$ \\
\hline Other fruit bats (\%) & $2(18)$ & $2(22)$ & $2(17)$ \\
\hline Nectarivore taxa (\%) & $1(9)$ & $1(11)$ & $2(17)$ \\
\hline Insectivore taxa (\%) & $5(45)$ & $3(33)$ & $4(33)$ \\
\hline \multicolumn{4}{|l|}{ Taxa relative to island elevation and area } \\
\hline Elevation (m) & 1,397 & 950 & 1,234 \\
\hline Island area (sq km) & 1,060 & 617 & 345 \\
\hline All taxa / elevation (x 1,000) & 7.9 & 9.5 & 9.7 \\
\hline All taxa / area $(\times 1,000)$ & 10.4 & 14.6 & 34.8 \\
\hline Fruit bat species / elevation (x 1,000) & 2.9 & 4.2 & 3.2 \\
\hline Fruit bat species / area $(\mathrm{x} 1,000)$ & 3.8 & 6.5 & 11.6 \\
\hline Nectarivore species / elevation $(x 1,000)$ & 0.7 & 1.1 & 0.8 \\
\hline Nectarivore species / area (x 1,000) & 0.9 & 1.6 & 2.9 \\
\hline Insectivore species / elevation (x 1,000$)$ & 3.6 & 3.2 & 2.4 \\
\hline Insectivore species / area (x 1,000) & 4.7 & 4.9 & 8.7 \\
\hline \multicolumn{4}{|l|}{ Sampling effort } \\
\hline Locations & 24 & 20 & 28 \\
\hline Number of nets & na & 119 & 172 \\
\hline Netting locations west:east & 13:11 & 10:10 & $14: 14$ \\
\hline Netting locations above:below $250 \mathrm{~m}$ & $12: 12$ & $10: 10$ & $14: 14$ \\
\hline Natural roosts visited & na & 2 & 8 \\
\hline \multicolumn{4}{|l|}{ Capture data (\% of captures) } \\
\hline All species & 1,859 & 1,520 & 1,679 \\
\hline Fruit bats (\%) & $1,244(67)$ & $1,125(74)$ & $1,010(60)$ \\
\hline Artibeus only (\%) & $612(33)$ & $998(66)$ & $766(45)$ \\
\hline Nectarivores (\%) & $259(14)$ & $160(11)$ & $480(23)$ \\
\hline Insectivores (\%) & $356(19)$ & $229(15)$ & $233(14)$ \\
\hline \multicolumn{4}{|l|}{ Capture rates-Bats per net-night } \\
\hline Fruit bats & na & 9.4 & 5.8 \\
\hline Artibeus only & na & 8.4 & 4.4 \\
\hline Nectarivores & na & 1.3 & 2.8 \\
\hline Insectivores & na & 1.9 & 1.3 \\
\hline Island average & na & 12.2 & 10.2 \\
\hline
\end{tabular}


(Pedersen et al. 2013), our cave surveys did not increase the number of species found on either St. Lucia or St. Vincent. Future efforts on St. Lucia must focus on locating roosts and their potential denizens, such as $N$. stramineus, P. fuscus, M. buriri, G. longirostris, and at least one species of Myotis.

Paleoclimatology and storm transport.-The present-day climate in the Lesser Antilles is dictated in part by the seasonal displacement of the inter-tropical convergence zone (ITCZ), which moves north of the Equator in summer and then south of the Equator in winter (Royer et al. 2017). At a much greater time scale, the paleoclimatological data indicate that the mean position of the ITCZ moves significantly to the north during interglacial periods and then south during glacial periods (Schmidt and Spero 2011). It has done this at least twice during the last 11,000 years (Hodell et al. 1991; Fritz et al. 2011; Malaizé et al. 2011). When the ITCZ is located to the south, storms penetrate the Caribbean directly from the east. When the ITCZ swings to the north, it pushes hurricane tracks and generally drier conditions along the Lesser Antilles towards the Bahamas (Royer et al. 2017). Such shifts typically leave the southern Lesser Antilles with a moist, relatively storm-free period that may affect occupation and colonization of those islands by bats.

Along a storm's path, the worst damage is typically associated with the right-front quadrant of the storm. Empirical data indicates that the primary debris field (such as bats and birds) is most likely to be spread across a zone $10^{\circ}$ to $35^{\circ}$ to the left of the storm path (Snow et al. 1995). When the ITCZ moves southwards, bats are likely to be ejected from the storm over open-ocean without a chance of landfall. When the ITCZ moves to the north, storms skirt to the east along the archipelago, shedding a debris field over islands to the NW-NNW of the storm track. Storm transport of bats from the south to St. Lucia is therefore more likely than bats being "blown" to St. Lucia from the north, regardless of time scale. However, the Atlantic trade winds blow steadily $(18-20 \mathrm{~km} / \mathrm{hr}$ ) from the northeast, toward the Equator, throughout the Antilles at the present time. These winds could provide some assistance to bats moving southwards along the archipelago.

Increasingly sophisticated radars have detected large birds flying within the eye of hurricanes (e.g.,
Hurricane Arthur in 2014, Hurricanes Hermine and Mathew in 2016). The transport of birds by hurricanes is not unusual (Tuck 1968; Dionne et al. 2008), but the survival rate of birds lofted by different parts of a storm is unknown. In terms of bats, Hurricane Ivan, which passed over Grenada on 7 September 2004, presumably moved bats through the southern Lesser Antilles (A. lituratus, Genoways et al. 2010) and the Cayman Islands (A. jamaicensis, Fleming and Murray 2009). Storms have also carried A. jamaicensis from St. John to St. Croix (banded animal: Rafe Buolon, personal communication) and at least four species of bat (Erophylla sezekorni, Phyllonycteris poeyi, Artibeus jamaicensis, and Phyllops falcatus) from Cuba to Florida, with each known from only one or two individuals and "have only been found in the Florida Keys and south Miami" (Florida Bat Conservancy 2017), but there is no evidence to suggest that any populations were established.

Several taxa would seem more capable of deterministic dispersal between Lesser Antillean islands (Lawlor 1986; Lomolino 1986; Patterson and Atmar 1986). This ability is driven by at least two thingssheer size and power of the larger bats, and wing shape. For example, the long narrow wing shape in $P$. davyi, $T$. brasiliensis, and $M$. molossus supports efficient longdistance flights (aspect ratios of 8.0-9.0) (Norberg and Rayner 1987; Vaughan et al. 2004; Marinello and Bernard 2014). At the other end of the spectrum, the short round wings of $N$. stramineus, $M$. buriri, A. nichollsi, S. angeli, S. paulsoni, and M. martiniquensis and nyctor (aspect ratios of 5.3-5.9) impose substantial limits on long distance movement, deterministic or otherwise. However, despite their small size and apparent fragility, Natalus, Micronycteris, and Myotis are found on several islands in the archipelago, thus indicating that they are more robust than they appear, or are disturbance adapted, or at least disturbance tolerant (Pedersen et al. 1996, 2010, 2013; Arendt et al. 1999; Hilton et al. 2003; Frank et al. 2017).

Human impact.-An increasing number of studies are reporting new fossil records of bats and other vertebrates, in each case attributing population declines, extirpation, and extinction of Caribbean bats to humans (Steadman et al. 1984b, 2015; Pregill et al. 1988; Bailon et al. 2015; Soto-Centeno and Steadman 2015; Boudadi-Maligne et al. 2016; Stoetzel et al. 2016; Valente et al. 2017), rather than to sea level and 
climate change during the Holocene (sensu Dávalos and Russell 2012).

Beginning approximately 6,000 years ago, there were four waves of human colonization of the West Indies (Lithic, Archaic, Ceramic, and European), the first from Mesoamerica and the next two from South America (Davis 2000; Fitzpatrick and Keegan 2007; Fitzpatrick 2012, 2015; Siegel et al. 2015) and the last from Europe. These movements were more likely influenced by seafaring technology and ocean currents than by geographic distance. Paradoxically, the southern islands of the Lesser Antilles were colonized relatively late (Cooke et al. 2017), with the islands of St. Lucia and St. Vincent being among the last to be occupied by humans-1,395 and 1,650 years ago, respectively (Fitzpatrick et al. 2015).

During the Archaic Age, volcanic activity was more frequent south of the Guadeloupe Passage than to the north. Indeed, the Soufrière volcano on St. Vincent buried several prehistoric sites under a deep blanket of ash, around 295 AD (Bullen and Bullen 1972). Such eruptions may have been a deterrent to prehistoric settlement in the southern Lesser Antilles (Callaghan 2007, 2010; Fitzpatrick 2012).

Bats were a common decorative motif on ceramic vessels during the period 1,500 to 500 years ago (Fitzpatrick 2015; Giovas 2017), but there is only limited zooarchaeological evidence of bats in the western Caribbean (Newsom and Wing 2004). There is no evidence of consumption of bats as a food item and their presence in these archaeological sites is most likely incidental (but see Olson and Nieves-Rivera 2010). If humans impacted bat populations it would have been primarily driven by their destruction of roosts and forest ecosystems.

As humans moved throughout the island chain, they had an adverse impact on both floral and faunal biodiversity (Wilson 1989; Versteeg and Schinkel 1992; Grouard 2001; Giovas et al. 2012; Giovas and Fitzpatrick 2014; Braje et al. 2017) via the clearing of native forest for the cultivation of invasive crop plants (Richardson et al. 2000). Habitat alteration and destruction intensified again with the increasing mechanization of agriculture by European colonists, over the last
500 years (Kimber 1988; Stoetzel et al. 2016). Early humans were also responsible for the culinary-driven extirpation of native vertebrates and invertebrates, the introduction of "semi-domesticated" mammals from South America (Giovas et al. 2012; Cooke et al. 2017; Welch and Leppanen 2017), and the transmission of zoonoses and parasites (Braje et al. 2017) to the native mammals. The scale of these activities undoubtedly varied from island to island (Rick et al. 2013). For example, Carriaçou is unusual among the islands of the Lesser Antilles for its combination and concentration of introduced South American mammals. Multiple mammal introductions to the island occurred between 1,250 to 550 years ago, including peccary, guinea pig, armadillo, opossum, and agouti.

Archaic, pre-Columbian, and colonial populations of humans used caves and natural cavities for shelter, but it is difficult to imagine how such use could affect the bat population on St. Lucia differently than those on the adjacent islands. However, caves and rock shelters on St. Lucia were used heavily on a regular basis throughout the 1790's during the Brigand rebellions (Harmsen et al. 2012) and many of these were subsequently destroyed by the British (Devaux 1997). It is unlikely that destruction of multiple roost sites on St. Lucia would extirpate entire species of bat, because many "cave-obligate species" will adopt alternate roost types if caves are not available (Rodríguez-Durán 2010; Soto-Centeno and Steadman 2015). However, the loss of even a single roost can impact an island's fauna (Genoways et al. 2007b) and the five insectivorous bats that are missing on St. Lucia are typically considered to be cave dwellers.

After surviving climate change and rising sea levels from 15,000 to 9,000 years ago, it is difficult to understand how so many cave dwelling species (primarily mormoopids) in the northern half of the Lesser Antilles were presumably extirpated by small bands of archaic humans some 6,000 years later (Steadman et al. 1984a, 1984b, 2015; Pregill et al. 1988, 1994; Soto-Centeno and Steadman 2015; Stoetzel et al. 2016). However, these extinctions may be exaggerated by survey effort and bias - caves are commonly visited during both archeological and paleontological work in the Antilles and caves provide a microenvironment where the chances of fossilization are very good (Velazco 
and Patterson 2013). Notably, fossils of Ardops and Lasiurus appear in fossil strata that are well correlated with climatic shifts (Stoetzel et al. 2016), but this is not because these species inhabit the caves, it is because their carcasses were incidentally carried back to the roosts by the actual denizens of the cave-American kestrels (Lenoble et al. 2014b) and owls (Bailon et al. 2015; Gala and Lenoble 2015; Steadman et al. 2015; Stoetzel et al. 2016; Pelletier at al. 2017; Soto-Centeno et al. 2017). In fact, owls would seem to have done an excellent job at documenting bat biodiversity (SotoCenteno et al. 2017).

Island elevation and species diversity.-The number of species found on an island is correlated with the diversity of habitats available, which could be affected more by elevation than island size per se (MacArthur and Wilson 1967; Daltry 2009; Steinbauer et al. 2016). This is because elevation influences plant communities and habitat diversity in the West Indies, which should equate to a greater diversity of bats on the taller islands. Evaluation of such relationships is best conducted via simple species-elevation and speciesarea regression analyses (Mathews et al. 2015). The relative position of an island above or below the "curve" is of great importance; that is, those islands that fall above the curve exceed their species richness as predicted by either island area or elevation. Conversely, those islands that fall below either of these curves fall short of their predicted species richness.

Ricklefs and Lovette (1999) developed a specieselevation curve for the Lesser Antilles using 15 islands for which they had reliable survey data for four faunal groups (birds, bats, butterflies, and reptiles and amphibians). Our log-log species-elevation curve is more complete and is based on 25 islands in Lesser Antilles (Fig. 16a, Table 4). The majority of these data stem from our work conducted since the mid1970s on the islands of Anguilla, Antigua, Barbados, Barbuda, Dominica, Grenada, Guadeloupe, Montserrat, Nevis, Saba, St. Bart's, St. Eustatius, St. Kitts, St. Lucia, St. Maarten/St. Martin, St. Vincent, and five of the Grenadine islands. Our curve also includes three recent island records: Chiroderma improvisum from St. Kitts (Beck et al. 2016) and Nevis (Burton Lim in 2016 and Kevel Lindsay in 2017, personal communication), and M. plethodon from St. Eustatius (Pedersen et al. 2018) (Table 2). We found a significant relationship between island elevation and species diversity (Table 4), whereas this was not the case for bats in the study done by Ricklefs and Lovette (1999).

Six of the Limestone Caribbees (Anguilla, Antigua, Barbuda, Grande-Terre Guadeloupe, Marie Galante, and St. Maarten/Martin) fall above the curve, indicating that they are more diverse than predicted by their elevation (Fig. 16a). This may be tied to the abundant caves on these islands, which provide critical refugia for bats during the breeding season and in times of natural disaster. Three of the Limestone Caribbees (St. Bart's, La Désirade, and Barbados) and five of the Grenadines fall below the curve, this being attributed to their small sizes and arid habitats. Barbados falls below the line, but this may be due to its recent geological age of about 1 million years.

All 11 of the Volcanic Caribbees have elevations greater than $600 \mathrm{~m}$ and each has at least six species of bat. Eight of these islands, including St. Lucia, sit above the line and have at least nine species of bat. St. Vincent is not only located above the line but outside of the $95 \%$ percentile, thus indicating that it is significantly species-rich in comparison to its two neighbors. Predictably, these data reflect the positive relationships found among tall islands, habitat diversity, and diverse bat communities. It follows, that high-elevation, wet forests may serve as critical ecological refugia during times of climate change in the future (LaVal 2004; Soto-Centeno et al. 2017) and/or these tall islands may serve as a "source" that could maintain the species pools in the region, pursuant to natural or human-mediated disasters (Carstensen et al. 2012).

Four of the 25 islands in this study are very flat and have elevations of less than $250 \mathrm{~m}$ - two of these islands are located at the north end of the chain (Anguilla and Barbuda), Grande-Terre Guadeloupe lies in the middle, and Mustique lies to the south in the Grenadines. The first three of these have more species than their respective elevations would suggest and are obvious outliers in Figure 16a. This is most likely a consequence of the availability of abundant cave roosts located on these particular islands. 
a.

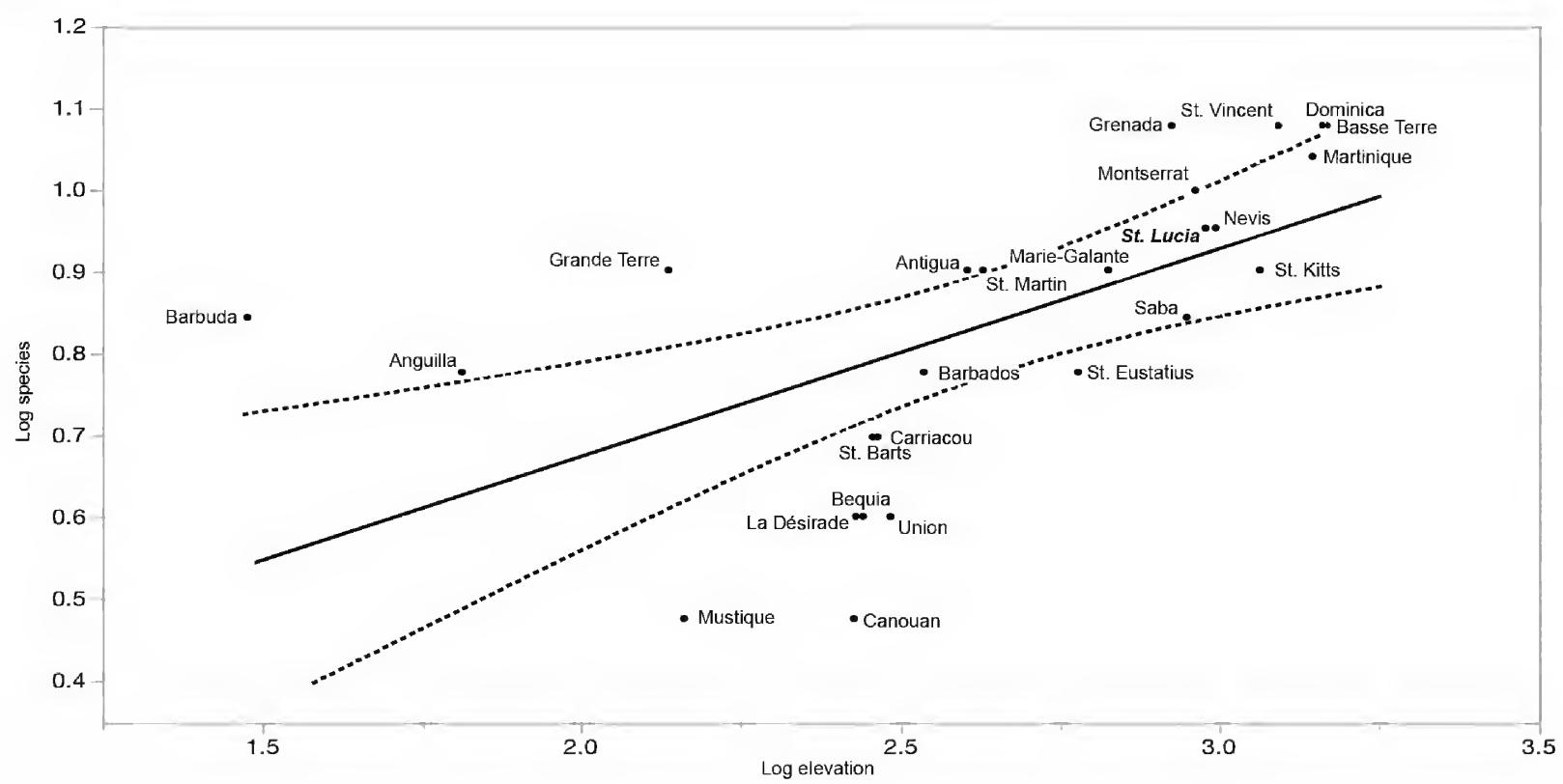

b.

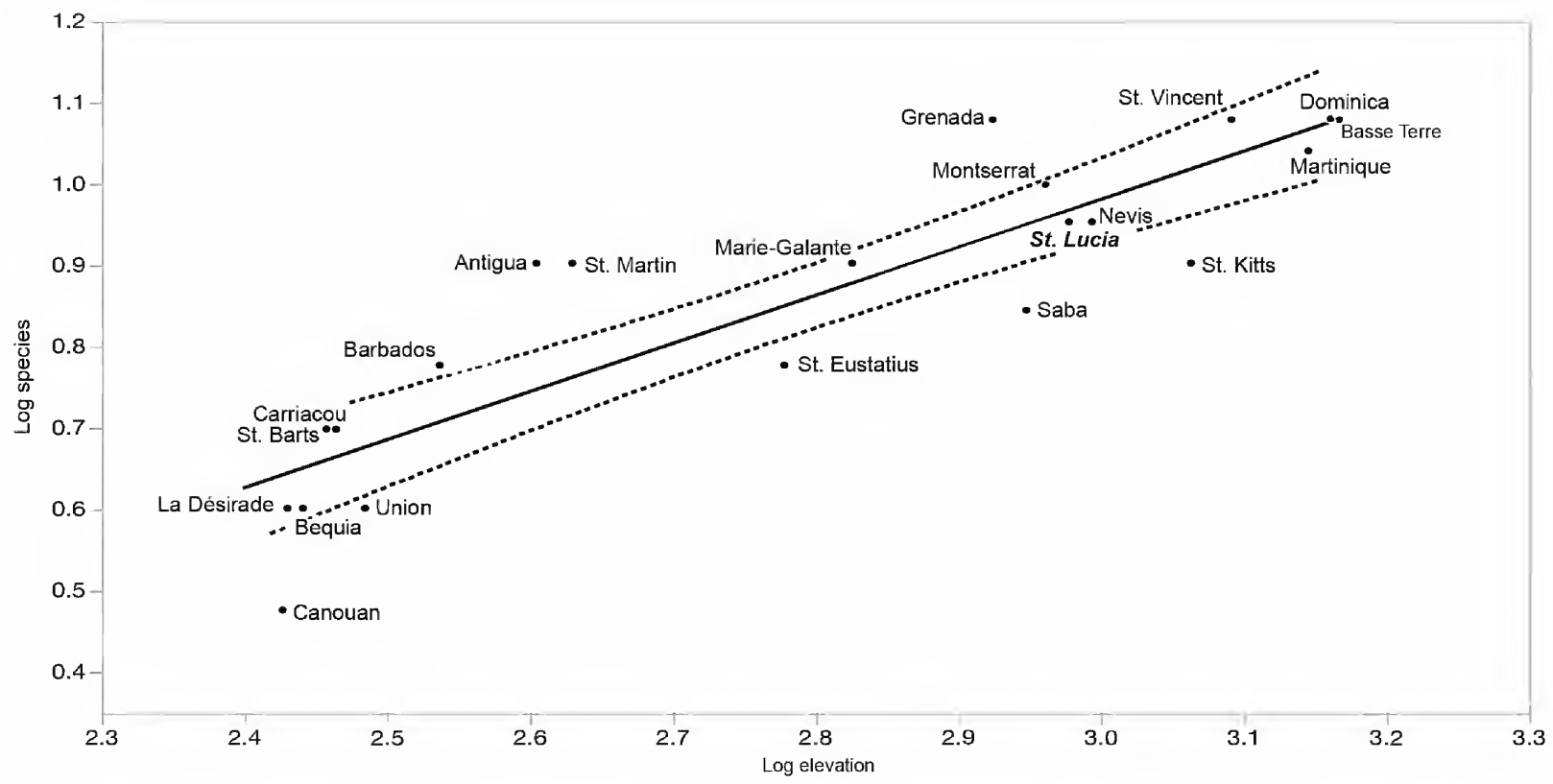

Figure 16. a) Species-elevation curve for 25 islands in the Lesser Antilles. Log species $=0.168+0.254 \mathrm{x}$ Log elevation, $\mathrm{R}^{2}=0.351$. b) Species-elevation curve for a subsample of 21 islands in the Lesser Antilles with a maximum elevation of $250+m$. Log species $=-0.789+0.590 \times \log$ elevation, $\mathrm{R}^{2}=0.788$. 


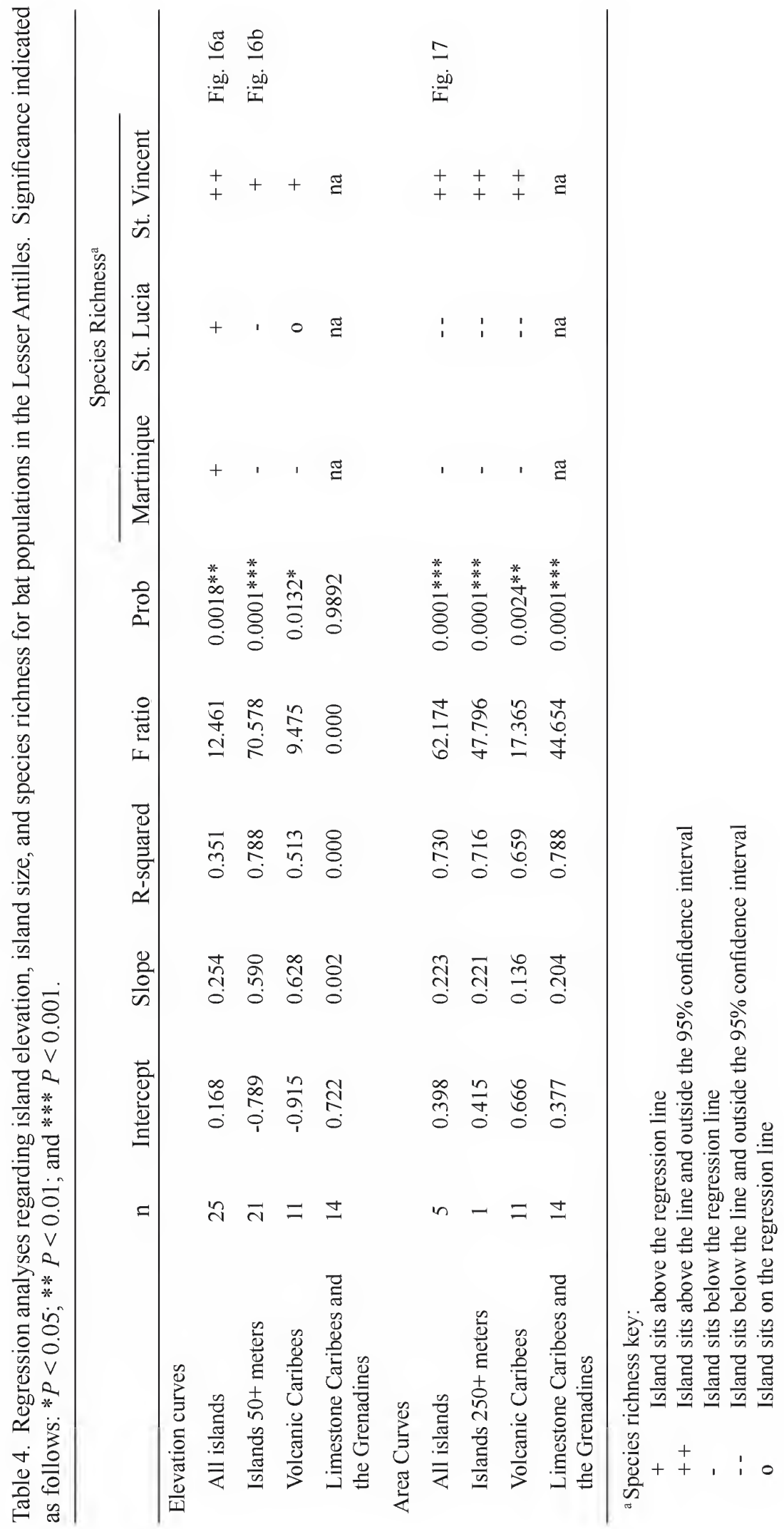


To explore the affect that these flat islands may have on our understanding of the system, we conducted a separate analysis of a reduced data set of the 21 islands that exceed $250 \mathrm{~m}$ in maximum elevation. This grouping is not inconsequential-habitats above $250 \mathrm{~m}$ are cooler and wetter due primarily to islandgenerated weather. As such, orographic wet forests are found in the interior or on the leeward side of these taller islands, which in concert serve as a more ecologically appropriate data set against which to evaluate the presumed "depauperate" fauna of St. Lucia (Fig. 16b). Predictably, the explanatory power of this second species-elevation curve increased substantially from an $R$-squared of 0.35 to 0.79 (Table 4). Although the positions of Martinique, St. Lucia, and St. Vincent did not change relative to each other, their locations shifted relative to the steeper curve. St. Lucia and Martinique dropped to just below the line and all three islands fall within the $95 \%$ confidence limits. Four of the eleven volcanic Caribbees sit above the line, whereas five of the Limestone Caribbees and Carriaçou sit above the line in Fig. 16b. Two additional species-elevation curves were derived, one for the Volcanic Caribbees and the other for the Limestone Caribbees + Grenadines (Table 4), but both had poor statistical support relative to those data depicted in Fig. 16b.

Four species of bat were rarely netted outside of moist forests on St. Lucia: $89 \%$ of the Monophyllus were netted in forest, between 200 and $300 \mathrm{~m}$ (and presumably at higher elevations); $95 \%$ of the Sturnira captured were netted in forest, above $200 \mathrm{~m}$ (mostly at 200-300 m); 41 of the 42 Ardops captured were netted in forests within a very narrow range of elevations, 294 to $319 \mathrm{~m}$; and $92 \%$ of the Pteronotus were netted in forest, above $250 \mathrm{~m}$. The small number of Monophyllus and Sturnira that were netted outside the forest and below $200 \mathrm{~m}$ on St. Lucia probably represent facultative foraging trips, rather than a para-montane distribution, that is, species that roost at one elevation but habitually forage at another (sensu Koopman 1983). Of these, M. plethodon, S. paulsoni, and A. nichollsi are Lesser Antillean endemics.

Endemism and species richness increase with elevation on islands (Steinbauer et al. 2016). For those islands listed in Table 2, the percent of endemic species differs between the Limestone Caribbees and the
Volcanic Caribbees, effectively a dichotomy between those islands with maximum elevations either below or above $600 \mathrm{~m}$ (39.6\% and $50.5 \%$, respectively). This equates to having two additional endemic species on tall volcanic islands and these are most often single-island records of insectivorous moist forest bats ( $P$. fuscus, $M$. buriri, E. fuscus [Dominica], E. guadeloupensis, and M. martiniquensis) (Table 2). Three of these (P. fuscus, $M$. buriri, and M. martiniquensis) have not been found on St. Lucia. On St. Vincent, M. buriri has been netted only in a narrow band of higher elevations (242-640 $\mathrm{m})$, which may partially explain the absence of this unique bat on St. Lucia. None of the plant-visiting bats that are "missing" on St. Lucia (A. lituratus and G. longirostris) are elevation-restricted and only $A$. jamaicensis $\times$ schwartzi is a Lesser Antillean endemic.

Despite this impression of a depauperate fauna, St. Lucia has the predicted number of species for its elevation and the relative number of insectivorous bats that were netted was similar to that of the adjacent islands of Martinique and St. Vincent (16\%, 13-19\%) (Table $3)$. Enigmatically, this net-presence is effectively half of that noted on islands with more comparable elevations to the north (40\%, 23-63\%; Antigua, Barbuda, Montserrat, Nevis, Saba, St. Eustatius, St. Kitts, and St. Martin), which like St. Lucia, do not have moist forest insectivorous bats.

Island area and the last glacial maximum.-We derived a species-area curve based on 25 islands in the Lesser Antilles (Fig. 17, Table 4). The slope of our curve $(0.223)$ is similar to that of Ricklefs and Lovette (Slope $=0.232,14$ islands; see discussion above; Ricklefs and Lovette 1999) and that of Willig et al. (slope $=0.262,23$ islands; Willig et al. 2010). With its dearth of insectivorous bats, St. Lucia sits below the line and outside of the $95 \%$ confidence limit in Figure 17. Conversely, St. Vincent sits above the line and outside of the $95 \%$ confidence limit indicating that it is as species-rich as St. Lucia is species-poor, in regard to both island area and island elevation. This pattern is seen in the other species-area curves listed in Table 4.

Most of the Volcanic Caribbees exhibit conical aprons that may extend as far outward as 3,000 to 4,000 $\mathrm{m}$ from the current shoreline at a fairly constant depth of 40-60 m. During the last glacial maximum, these 


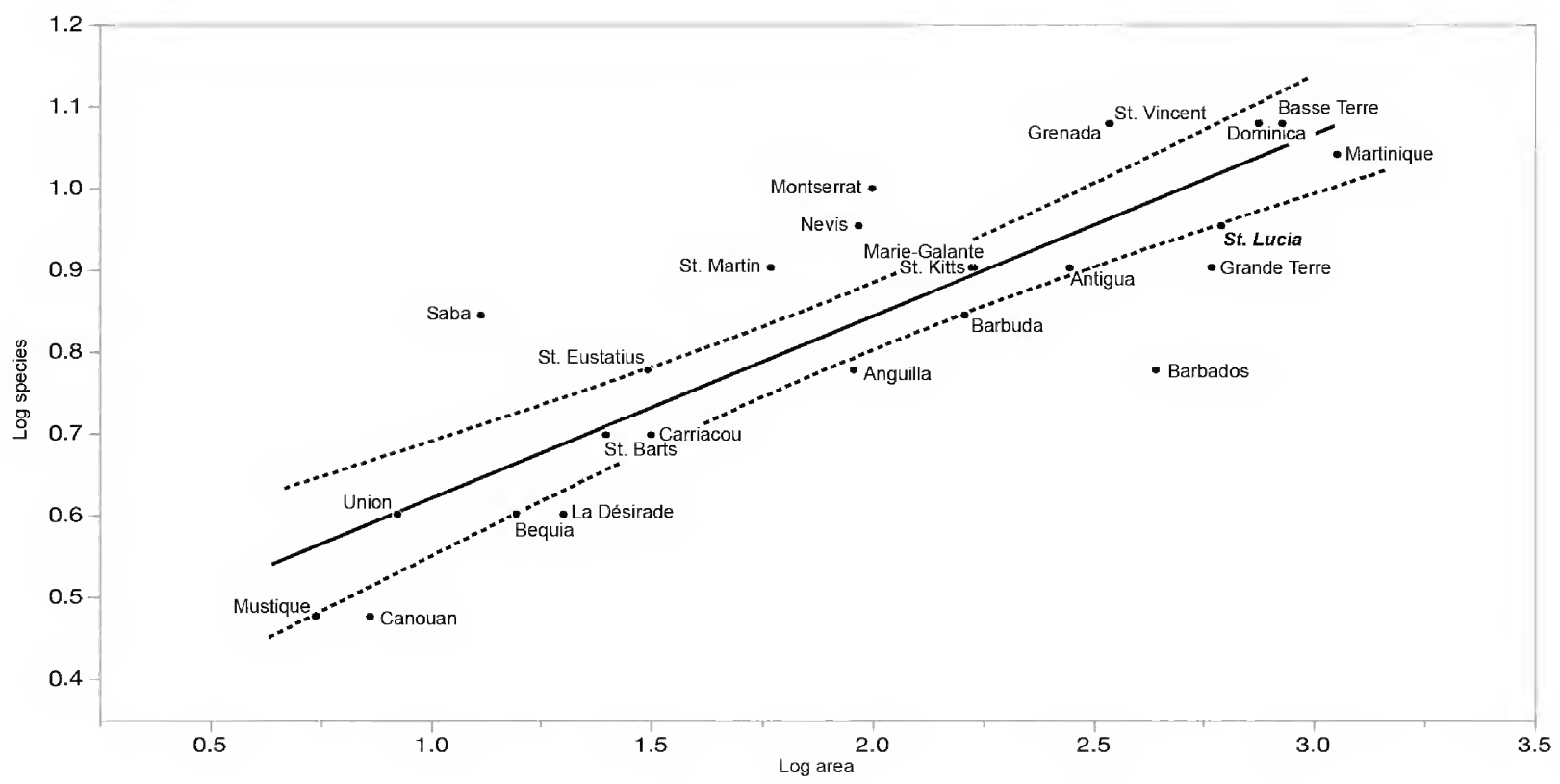

Figure 17. Species-area curve for 25 islands in the Lesser Antilles. Log species $=0.398+0.223 \times$ Log area, $R^{2}=0.730$.

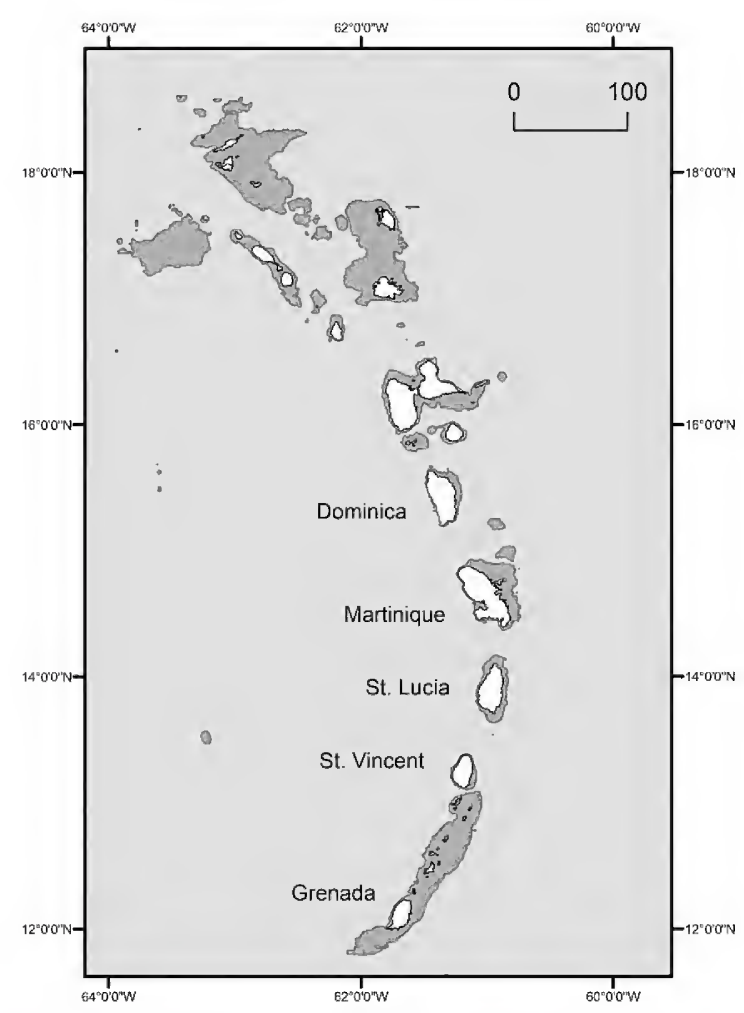

Figure 18. Bathymetric map of the Lesser Antilles. Dark grey shading represents potential extent of exposed land during the Pleistocene at last glacial maximum $(26,500$ to 19,000 years before present; sea levels $\sim 130$ m below present). aprons were exposed as sea levels were $\sim 130$ to $120 \mathrm{~m}$ lower than present day, thereby increasing the absolute size of these islands, but not necessarily increasing the amount of habitat diversity usable by bats (Fig. 18). Regardless, the distance between St. Vincent and St. Lucia, and between St. Lucia and Martinique, would have changed very little due to abrupt geological features (deep water passages) to the north and south of St. Lucia. Despite changes in island area during the late Pleistocene, these relatively static inter-island distances would have made movement of bats among these three islands much as it is today.

Dávalos and Russell (2012) developed a model to test if changes in sea level during the last glacial maximum (LGM) were responsible for extirpations and extinctions of bats throughout the Antilles. Their model showed that island area during the LGM was well correlated with species richness in the Greater Antilles and Bahamas. However, their model indicated that island area did not correlate well with species richness in the Lesser Antilles, during the LGM. This they attributed to a poor fossil record in the Lesser Antilles. Recent fossil data from Marie Galante would have affected their results, but these data were not available to them at the time, i.e., Stoetzel et al. (2016) and Royer et al. (2017). Nevertheless, their model inexplicably neglected the survey data published between 2003 and 2012 (by the 
authors) from seven islands: Saba, St. Kitts, Nevis, Montserrat, Martinique, Grenada, and Barbados. Yet, Dávalos and Russell (2012) included Tintamarre, a 100 -hectare island northeast of St. Maarten/Martin, which does not have any bats. Their depauperate 2012 data were therefore insufficient to support their claims regarding island area and species richness in the Lesser Antilles, in either the past or the present. Below, we redress their model with a more complete data set and with more attention paid to the geological differences between the Volcanic and Limestone Caribbees (Table 2).

Island elevation, island area, and the presence of caves.-We used a multiple regression analysis $(\mathrm{R}$ Development Core Team 2008) to investigate which factor-island elevation or island area-best predicts bat species richness in the Lesser Antilles (Table 5). In the greater sample of 25 islands, the combination of island elevation and island area accounts for $82 \%$ of the overall variance $(R$-squared $=0.8168)$ and island area accounts for $\sim 60 \%$ of that. In the subsample of 21 islands that are 250 meters in elevation or higher, island elevation and island area account for $88 \%$ of the overall variance $(R$-squared $=0.8803)$ and island elevation accounts for the majority of that $(\sim 7 \%)$. This increase in $R$-squared and the apparently greater effect of island elevation on species richness is an artifact of the reduced sample of islands with elevations greater than $250 \mathrm{~m}$ (Table 4). This latter result supported our assumption, and those of others, that island elevation is an effective proxy for habitat diversity, plant biodiversity, and hence species richness in the bat fauna.

However, island area better explains species richness than does habitat diversity (elevation) for the greater sample of 25 islands (Table 2). Though ecologically counterintuitive, this result is driven primarily by three islands that have far more species than predicted by their elevation: Anguilla, Barbuda, and Grande-Terre (Guadeloupe) (Fig. 16a). Despite their relative dearth of habitat, the abundant caves on these islands have made them ecological sinks (Pulliam 1988; Carstensen et al. 2012) that tend to "collect" species. This result not only underlines the importance of cave conservation on islands (Genoways et al. 2007b), but also infers that simple regression models of biodiversity that do not consider the presence of caves may be illusory.
Perhaps, the apparently lower number of caves on the Volcanic Caribbees may be a reason for the lower than anticipated numbers of bats on these islands, of which St. Lucia is an obvious example.

Implications of the Artibeus hybrid swarm.-The identification of naturally occurring hybridization events is incredibly important from the perspective of evolutionary biology. This is because hybrid zones provide a unique window into the evolutionary tempo of the formation of genetic isolating mechanisms and the speciation process. Therefore, robust evidence of chiropteran hybridization is critical to the understanding of bat evolution and speciation. Although bats are one of the most speciose clades of mammals, documented cases of naturally occurring hybridization events are rare and only a handful of putative bat hybrid zones have been identified to date. This pattern is likely a consequence of poor taxon sampling and the limited deployment of genomic datasets that have the resolving power to elucidate ongoing or historical hybridization events.

Arguably one of the most well-defined bat hybrid zones is the Artibeus hybrid zone in the southern Lesser Antilles. This is because the data supporting hybridization among species of Caribbean Artibeus spans decades of research and includes a number of independent datasets (e.g., nuclear AFLPs, mitochondrial DNA genotyping and sequencing, and morphometrics) that collectively provide strong support for ongoing hybridization (see Artibeus jamaicensis $\times$ schwartzi species account above; Jones and Phillips 1976; Pumo et al. 1988; Phillips et al. 1989; P. Larsen et al. 2010). When examining the collective scope of these available datasets, alongside subfossil records from the Greater Antilles, genetic data from both Central and South American Artibeus populations, and an evolutionary timescale of diversification events within Artibeus (see P. Larsen et al. 2007, 2010, 2013), several critically important patterns emerge with respect to the origin of the Artibeus hybrid swarm that centers on the islands of St. Lucia and St. Vincent in the southern Lesser Antilles. It is important to note that these patterns are consistent with recent hypotheses regarding rapid hybrid speciation on insular systems and they are intimately tied to and likely facilitated by aspects of classical island biogeography (P. Larsen et al. 2010; Lamichhaney 
Table 5. Multiple regression analyses regarding species elevation and species area curves for bat populations in the Lesser Antilles. Significance indicated as follows: ${ }^{*} P<0.05 ; * * P<0.01$; and $* * * P<0.001$.

\begin{tabular}{|c|c|c|c|c|}
\hline \multicolumn{5}{|c|}{ All 25 islands in the study } \\
\hline Multiple regression & & Estimate & Std error & t ratio \\
\hline Intercept & & 0.099 & 0.105 & 0.95 \\
\hline Log Elevation & & 0.136 & 0.042 & $3.23 * *$ \\
\hline$\underline{\text { Log Area }}$ & & 0.191 & 0.256 & $7.48 * * *$ \\
\hline \multicolumn{5}{|c|}{ Multiple R-square $=0.813$} \\
\hline ANOVA & DF & Sum of squares & Mean square & $\mathrm{F}$ ratio \\
\hline Model & 2 & 0.674 & 0.337 & $49.06 * * *$ \\
\hline Error & 22 & 0.151 & 0.007 & \\
\hline Total & 24 & 0.825 & & \\
\hline Effect tests & & Sum of squares & $\mathrm{F}$ ratio & \\
\hline Log Elevation & 1 & 0.071 & $10.435 * *$ & \\
\hline Log Area & 1 & 0.384 & $55.907 * * *$ & \\
\hline
\end{tabular}

Islands with elevations above 250 meters $(n=21)$

\begin{tabular}{llll} 
Multiple regression & Estimate & Std error & t ratio \\
\hline Intercept & -0.440 & 0.178 & $-2.49^{*}$ \\
Log Elevation & 0.385 & 0.077 & $4.98^{* * *}$ \\
Log Area & 0.113 & 0.030 & $3.73^{* *}$ \\
\hline Multiple R-square $=0.878$ & &
\end{tabular}

\begin{tabular}{lllll} 
ANOVA & DF & Sum of squares & Mean square & F ratio \\
\hline Model & 2 & 0.599 & 0.299 & $66.18^{* * *}$ \\
Error & 18 & 0.081 & 0.004 & \\
\hline Total & 20 & 0.681 & &
\end{tabular}

\begin{tabular}{llll} 
Effect tests & & Sum of squares & F ratio \\
\hline Log Elevation & 1 & 0.112 & $24.769^{* * *}$ \\
Log Area & 1 & 0.062 & $13.892^{* *}$ \\
\hline
\end{tabular}

et al. 2018). These patterns include: 1) primary and secondary contact among evolutionary young congeners (including non-sister lineages) across an insular system; 2) primary or secondary contact occurring on small and ecologically monotypic islands; and 3) geographic position of a genetically and morphologically distinct phenotype on islands that are at the very center of an active hybrid zone. Each of these patterns are associated with the Artibeus hybrid zone in the southern Lesser Antilles, and they collectively provide the foundation for the hypothesis of a hybrid origin of A. schwartzi (P. Larsen et al. 2010). Moreover, they provide a unique window into the evolution of genetic isolating mechanisms within stenodermatine bats, the most recently evolved and most speciose clade of the Phyllostomidae. This is because hybridization among Artibeus jamaicensis, A. planirostris, and A. schwartzi on islands in the southern Lesser Antilles indicates that $\sim 4$ million years of evolution was an insufficient amount of time to evolve complete genetic isolating mechanisms (occurring in the absence of allopatric reinforcement; see P. Larsen et al. 2013).

The significance of the geographic location of $A$. schwartzi being at the center of an insular hybrid zone cannot be understated. This is because the distinct 
phenotype is consistent with the hypothesis that hybrid speciation is facilitated by the disruption of parental gene flow due to classical island biogeography, e.g., fluctuating island size and colonization success being tied to fluctuating climate and ecology (P. Larsen et al. 2010). In light of this observation, as well as the remarkably similar hypothesis of hybrid origins of Galapagos finches (Lamichhaney et al. 2018), we recommend additional studies aimed at identifying hybrid zones associated with insular systems. Targeting these hybrid zones using advanced genomic technologies will likely identify additional instances of hybrid speciation and will provide new, dynamic perspectives on biological evolution.

The depauperate bat fauna on St. Lucia remains an enigma.-The bat populations in the Lesser Antilles are shaped by asynchronous variation in speciation, colonization, and extinction rates among taxa. These are affected by more than just island complexity and isolation alone. As we have noted elsewhere, the adaption of the bats themselves to the new island conditions can shape these numbers (Kwiecinski et al. 2018). In turn, biodiversity data sit precariously atop differential survey bias, idiosyncrasies or a lack of a fossil record, the asynchronous shifting of the ITCZ, the stochastic effects of major storms and shifting of the trade winds, the influence of humans during the last 2,000 years, and certainly the looming effects of climate change in the next 200 years (Gannon and Willig 2010; Pedersen et al. 2010; Rodriguez-Duran 2010; Willig et al. 2010;
Conenna et al. 2017). As such, biodiversity estimates and conservation guidelines can only be approximations at best and almost certainly underestimate the true faunal diversity of any of the Lesser Antillean islands. There remains a need to collect and interpret data on natural dispersal so that movements between the mainland and islands and among oceanic islands themselves become understood and that the natural barriers to dispersal are better defined.

Despite this daunting collection of unknowns, the enigmatic bat fauna of St. Lucia begs further study and analysis. Are the species discussed above actually "missing" from the chiropteran fauna of St. Lucia? This could change with the next additional field expedition to the island (sensu Lindsay et al. 2010; Beck et al. 2016). In the future, acoustic surveys should be utilized to help focus mist netting efforts. Such efforts must also include searches for caves and other natural roosts. Therein, efforts to locate owl roosts and owl pellets could provide evidence of species of bat that evade mist nets and/or cavernicolous species that are roosting in undisclosed caves or seeking shelter in non-cave roosts. Finally, because island-dwelling bats face increasing threats to their environments by humans (Jones et al. 2003; Conenna et al. 2017), we advocate for future research efforts to be directed towards understanding the natural history of the least-known island endemic species system-wide and to apply what funding there is to conservation efforts.

\section{ACKnOWledgements}

We thank Alwin Dornelly (Head of Research, Department of Forestry) for his tremendous efforts in all phases of our survey work on St. Lucia. We thank Michael Anthony (Head of Wildlife), Michael Bobb (Senior Forestry Officer), and Alwin Dornelly for arranging the MOU that supported our survey efforts and for Michael Andrew (Chief of Forestry) for providing the Export Permit. We appreciate the help of the Department of Forestry with communications and guidance to potential netting sites. In particular, we thank the Department of Forestry for arranging for their Officers and others to meet us at several localities: Tim Baptiste at Marquis Estate; Alwin Dornelly and Matt Morton, Woodland Estate; Lester Jean-Baptiste,
Edmond Forest Reserve; Stephen Lesmond, Quilesse Forest Reserve Trail; Adam Michelle, Forestière Nature Trail; and the Soufrière Marine Management Association. Robert J. Devaux OBE kindly provided his expert knowledge of the island's geography, history, and the locations of several caves that we surveyed for bats. Our work on St. Lucia was also made possible by the cooperation and good humor extended to us by several landowners who gave us access to their properties and by Corporal Elias Auguste of the Micoud Police.

We thank our colleagues for sharing their unpublished survey data with us: Rafe Buolon, François Catzeflis, Burton Lim, and Kevel Lindsay. 
We appreciate the cooperation of the following curators and collection managers for allowing us access to study specimens in their care: Nancy B. Simmons, American Museum of Natural History (AMNH); Richard W. Thorington, Jr., and Linda K. Gordon, National Museum of Natural History (NMNH); Robert M. Timm, University of Kansas (KU); Robert J. Baker and Heath Garner, Museum of Texas Tech University (TTU); Patricia W. Freeman and Thomas E. Labedz, University of Nebraska State Museum (UNSM). We also appreciate the statistical assistance provided by Jennifer Krauel (University of Tennessee, Knoxville).

Angie Fox, Technical Artist, University of Nebraska State Museum, prepared the distribution maps. Finally, we want to acknowledge the field assistance of our colleagues: Brandon Bales, Matt Clarke, Jeff Corneil, Jennifer Krauel, Matt Morton and Rachael Pedly (Durrell Wildlife), and Mike Roedel.

\section{Literature Cited}

Adams, J. K. 1989. Pteronotus davyi. Mammalian Species 346:1-5.

Allen, G. M. 1908. Notes on Chiroptera. Bulletin of the Museum of Comparative Zoology, Harvard College 52:25-62.

Allen, G. M. 1911. Mammals of the West Indies. Bulletin of the Museum of Comparative Zoology, Harvard College 54:175-263.

Andersen, K. 1908. A monograph of chiropteran genera Uroderma, Enchisthenes, and Artibeus. Proceedings of the Zoological Society of London 1908:204-319.

Arendt, W. J., and D. Anthony. 1986. Bat predation by the St. Lucia boa (Boa constrictor orophias). Caribbean Journal of Science 22:219-220.

Arendt, W. J., D. W. Gibbons, and G. Gray. 1999. Status of the volcanically threatened Montserrat oriole Icterus oberi and other forest birds in Montserrat, West Indies. Bird Conservation International 9:351-372.

Bailon S., C. Bochaton, and A. Lenoble. 2015. New data on Pleistocene and Holocene herpetofauna of Marie Galante (Blanchard Cave, Guadeloupe Islands, French West Indies): insular faunal turnover and human impact. Quaternary Science Reviews 128:127e137.

Baker, R. J., O. R. P. Bininda-Emonds, H. Mantilla-Meluk, C. A. Porter, and R. A. Van Den Bussche. 2012. Molecular timescale of diversification of feeding strategy and morphology in New World leaf-nosed bats (Phyllostomidae): a phylogenetic perspective. Pp. 385-409 in Evolutionary history of bats: fossils, molecules and morphology (G. F. Gunnell and N. B. Simmons, eds.). Cambridge University Press, Cambridge Studies in Molecules and Morphology-New Evolutionary Paradigms, New York. $\mathrm{xii}+560 \mathrm{pp}$.

Baker, R. J., H. H. Genoways, and J. C. Patton. 1978. Bats of Guadeloupe. Occasional Papers, Museum of Texas Tech University 50:1-16.

Baker, R. J., S. Solari, A. Cirranello, and N. B. Simmons. 2016. Higher level classification of phyllostomid bats with a summary of DNA synapomorphies. Acta Chiropterologica 18:1-38.

Barataud, M., S. Giosa, G. Issartel, and J. Jemin. 2011. Bioévaluation des forêts de Martinique par l'étude de l'activité des guildes de chiroptères. Rapport, Direction Régionale de l'Environnement, Martinique, $32 \mathrm{pp}$.

Barber, J. R., K. A. Razak, and Z. M. Fuzessery. 2003. Can two streams of auditory information be processed simultaneously? Evidence from the gleaning bat Antrozous pallidus. Journal Comparative Physiology A 189:843-855.

Beard, J. 1949. The natural vegetation of the Windward and Leeward Islands. Clarendon Press, Oxford. 192 pp.

Beck, J. D., A. D. Loftis, J. L. Daly, W. K. Reeves, and M. V. Orlova. 2016. First record of Chiroderma improvisum Baker and Genoways, 1976 (Chiroptera: Phyllostomidae), from Saint Kitts, Lesser Antilles. Check List 12(2):1-4.

Berry, N., W. O’Connor, M. W. Holderied, and G. Jones. 2004. Detection and avoidance of harp traps by echolocating bats. Acta Chiropterologica 62:335-346.

Blackburn, T. M., P. Pyšek, S. Bacher, J. T. Carlton, R. P. Duncan, V. Jarošík, J. R. U. Wilson, and D. M. Richardson. 2011. A proposed unified framework for biological invasions. Trends in Ecology and Evolution 26:333-339.

Boudadi-Maligne, M., S. Bailon, C. Bochaton, F. Casagrande, S. Grouard, N. Serrand, and A. Lenoble. 2016. Evidence for historical human-induced extinctions of vertebrate species on La Désirade (French West Indies). Quaternary Research 85:54-65.

Braje, T. J., T. P. Leppard, S. M. Fitzpatrick, and J. M. Erlandson. 2017. Archaeology, historical ecology and anthropogenic island ecosystems. Environmental Conservation 44:286-297.

Breen, H. H. 1844. St. Lucia: historical, statistical, and descriptive. Longman, Brown, Green, and Longmans publishing., London. 
Britton-Simmons, K. H., and K. C. Abbott. 2008. Short- and long-term effects of disturbance and propagule pressure on a biological invasion. Journal of Ecology 96:68-77.

Brown, J. H. 1986. Two decades of interaction between the MacArthur-Wilson model and the complexities of mammalian distributions. Biological Journal of the Linnean Society 28:231-251.

Bullen, R. P., and A. K. Bullen. 1972. Archaeological investigations on St. Vincent and the Grenadines West Indies. American Studies, Report Number Eight, The William Bryant Foundation, Orlando.

Callaghan, R. T. 2007. Prehistoric settlement patterns on St. Vincent, West Indies. Caribbean Journal of Science $43: 11-22$.

Callaghan, R. T. 2010. Crossing the Guadeloupe passage in the Archaic Age. Pp. 127-147 in Island shores, distant pasts: archaeological and biological approaches to the pre-Columbian settlement of the Caribbean (S. M. Fitzpatrick and A. H. Ross, eds.). University Press of Florida, Gainesville. 246 pp.

Caribbean Hurricane Network. 2015. <https://atlas.media.mit. edu/en/profile/country/lca/>.

Carstens, B. C., J. Sullivan, L. M. Dávalos, P. A. Larsen, and S. C. Pedersen. 2004. Exploring population genetic structure in three species of Lesser Antillean bats. Molecular Ecology 13:2557-2566.

Carstensen, D., B. Dalsgaard, J-C. Svenning, C. Rahbek, J. Fjeldså, W. Sutherland, and J. Olesen. 2012. Biogeographical modules and island roles: a comparison of Wallacea and the West Indies. Journal of Biogeography 39:739-749.

Cirranello, A., N. B. Simmons, S. Solari, and R. J. Baker. 2016. Morphological diagnoses of higher-level phyllostomid taxa (Chiroptera: Phyllostomidae). Acta Chiropterologica 18:39-71.

Clare, E. L., R. G. Holger, V. A. Drapeau, M. W. Holderied, A. M. Adams, J. Nagel, E. R. Dumont, P. D. N. Herbert, and M. B. Fenton. 2014. Trophic niche flexibility in Glossophaga soricina: how a nectar seeker sneaks an insect snack. Functional Ecology 28:632-641.

Clarke, F. M. 2009. The mammals of St. Lucia. National Forest Demarcation and Bio-Physical Resource Inventory Project, Forestry Department, Ministry of Sustainable Development, Energy, Science and Technology, Gabriel Charles Forestry Complex, Union, Castries, Saint Lucia. $92 \mathrm{pp}$.

Colautti, R. I., I. A. Grigorovich, and H. J. MacIsaac. 2006. Propagule pressure: a null model for biological invasions. Biological Invasions 8:1023-1037.

Conenna, I., R. Rocha, D. Russo, and M. Cabeza. 2017. Insular bats and research effort: a review of global patterns and priorities. Mammal Review 47:169-182.
Connor, E. F., and E. D. McCoy. 1979. The statistics and biology of the species-area relationship. American Naturalist 113:791-833.

Connor, E. F., and D. Simberloff. 1978. Species number and compositional similarity of the Galapagos flora and fauna. Ecological Monographs 48:219-248.

Connor, E. F., and D. Simberloff. 1979. The assembly of species communities: chance or competition? Ecology 60:1132-1140.

Cooke S. B., L. M. Dávalos, A. M. Mychajliw, S. T. Turvey and N. S. Upham. 2017. Anthropogenic extinction dominates Holocene declines of West Indian mammals. Annual Review of Ecology and Evolutionary Systematics 48:301-327.

Daltry, J. C. 2009. Biodiversity assessment of Saint Lucia's forests, with management recommendations. Technical Report No. 10 to the National Forest Demarcation and Bio-Physical Resource Inventory Project, FCG International Ltd, Helsinki, Finland.

Dávalos, L. M., and A. L. Russell. 2012. Deglaciation explains bat extinction in the Caribbean. Ecology and Evolution 12:3045-3051.

Davis, D. 2000. Jolly Beach and the preceramic occupation of Antigua, West Indies. Yale University Publications in Anthropology 84:1-146.

Davis, W. B. 1973. Geographic variation in the fishing bat, Noctilio leporinus. Journal of Mammalogy 54:862-874.

de la Torre, L. 1966. New bats of the genus Sturnira (Phyllostomidae) from the Amazonian lowlands of Peru and the Windward Islands, West Indies. Proceedings of the Biological Society of Washington 79:267-272.

de la Torre, L., and A. Schwartz. 1966. New species of Sturnira (Chiroptera: Phyllostomidae) from the islands of Guadeloupe and Saint Vincent, Lesser Antilles. Proceedings of the Biological Society of Washington 79:297-304.

Devaux, R. J. 1997. They called us Brigands: the saga of St. Lucia's freedom fighters. Optimum Printers Ltd., St. Lucia, $129 \mathrm{pp}$.

Dionne, M., C. Maurice, J. Gauthier, and F. Shaffer. 2008. Impact of Hurricane Wilma on migrating birds: the case of the Chimney Swift. The Wilson Journal of Ornithology 120:784-792.

Dobson, G. E. 1878. Catalogue of the Chiroptera in the collection of the British Museum. Trustees of the British Museum, London. xlii + 567 pp.

Dolan, P. G. 1989. Systematics of Middle American mastiff bats of the genus Molossus. Special Publications, Museum of Texas Tech University 29:1-71.

Fitzpatrick, S. M. 2012. On the shoals of giants: natural catastrophes and the overall destruction of the Caribbean's archaeological record. Journal of Coastal Conservation 16:173-186. 
Fitzpatrick, S. M. 2015. The Pre-Columbian Caribbean: colonization, population dispersal, and island adaptations. PaleoAmerica 1:305-331

Fitzpatrick, S. M., and W. F. Keegan. 2007. Human impacts and adaptations in the Caribbean islands: an historical ecology approach. Earth and Environmental Science Transactions of the Royal Society of Edinburgh 98:29-45.

Fitzpatrick, S. M., T. C. Rick, and J. M. Erlandson. 2015. Recent progress, trends, and developments in island and coastal archaeology. Journal of Island and Coastal Archaeology 10:3-27, https://doi.org/10.1080/1556489 4.2015.1013647.

Fleming, T. H., and K. L. Murray. 2009. Population and genetic consequences of hurricanes for three species of West Indian phyllostomid bats. Biotropica 41:250-256.

Florida Bat Conservancy. 2017. Accidental bat species in Florida. Accessed at $<$ http://www.floridabats.org/Species_Accidentals.htm $>$ on 10 August.

Francis, C. M. 1989. A comparison of mist nets and two designs of harp traps for capturing bats. Journal of Mammalogy 70:865-870.

Frank, H. K., L. O. Frishkoff, C. D. Mendenhall, G. C. Daily, and E. A. Hadly. 2017. Phylogeny, traits, and biodiversity of a Neotropical bat assemblage: close relatives show similar responses to local deforestation. American Naturalist 190:200-212, http://dx.doi.org/10.5061/dryad.mb552.

Fritz, S. C., S. Björck, C. A. Rigsby, P. A. Baker, A. CalderChurch, and D. J. Conley. 2011. Caribbean hydrological variability during the Holocene as reconstructed from crater lakes on the island of Grenada. Journal of Quaternary Science 26:829-838.

Gala, M., and A. Lenoble. 2015. Evidence of the former existence of an endemic macaw in Guadeloupe, Lesser Antilles. Journal of Ornithology 156:1061-1066.

Gannon, M. R., and M. R. Willig. 1994. The effects of Hurricane Hugo on bats of the Luquillo Experimental Forest of Puerto Rico. Biotropica 26:320-321.

Gannon, M. R., and M. R. Willig. 2010 (c2009). Island in the storm: disturbance ecology of plant-visiting bats in the hurricane-prone island of Puerto Rico. Pp. 281-301 in Island bats: evolution, ecology, and conservation (T. H. Fleming and P. A. Racey, eds.). University of Chicago Press, Chicago, Illinois. 549 pp.

Genoways, H. H. 1998. Two new subspecies of bats of the genus Sturnira from the Lesser Antilles, West Indies. Occasional Papers, Museum of Texas Tech University 176:1-7.

Genoways, H. H., R. J. Baker, J. W. Bickham, and C. J. Phillips. 2005. Bats of Jamaica. Special Publications, Museum of Texas Tech University 48:1-155.

Genoways, H. H., G. G. Kwiecinski, P. A. Larsen, S. C. Pedersen, R. J. Larsen, J. D. Hoffman, M. de Silva, C. J. Phillips, and
R. J. Baker. 2010. Bats of the Grenadine islands, West Indies, and placement of Koopman's Line. Chiroptera Neotropical 16:501-521.

Genoways, H. H., P. A. Larsen, S. C. Pedersen, and J. J. Huebschman. 2007a. Bats of Saba, northern Lesser Antilles. Acta Chiropterologica 9:91-114.

Genoways, H. H., R. J. Larsen, S. C. Pedersen, G. G. Kwiecinski, and P. A. Larsen. 2011. Bats of Barbados. Chiroptera Neotropical 17:1029-1054.

Genoways, H. H., S. C. Pedersen, P. A. Larsen, G. G. Kwiecinski, and J. J. Huebschman. 2007b. Bats of St. Martin, French West Indies/St. Maarten, Netherlands Antilles. Mastozoologica Neotropical 14:169-188.

Genoways, H. H., S. C. Pedersen, C. J. Phillips, and L. K. Gordon. 2007c. Bats from Anguilla, northern Lesser Antilles. Occasional Papers, Museum of Texas Tech University 270:1-12.

Genoways, H. H., C. J. Phillips, and R. J. Baker. 1998. Bats of the Antillean island of Grenada: a new zoogeographic perspective. Occasional Papers, Museum of Texas Tech University 177:1-32.

Genoways, H. H., R. M. Timm, R. J. Baker, C. J. Phillips, and D. A. Schlitter. 2001. Bats of the West Indian island of Dominica: natural history, areography, and trophic structure. Special Publication, Museum of Texas Tech University 43:1-44.

Gillespie, R. G., B. G. Baldwin, J. M. Waters, C. I. Fraser, R. Nikula, and G. K. Roderick. 2012. Long-distance dispersal: a framework for hypothesis testing. Trends in Ecology and Evolution 27:47-56.

Giovas, C. M. 2017. The beasts at large-perennial questions and new paradigms for Caribbean translocation research. Part I: Ethnozoogeography of mammals. Environmental Archaeology 1-17. https://doi.org/10.1080/14614103.2 017.1315208 .

Giovas, C. M., and S. M. Fitzpatrick. 2014. Prehistoric migration in the Caribbean: past perspectives, new models and the ideal free distribution of West Indian colonization. World Archaeology 46:569-589.

Giovas, C. M., M. J. LeFebvre, and S. M. Fitzpatrick. 2012. New records for prehistoric introduction of Neotropical mammals to the West Indies: evidence from Carriaçou, Lesser Antilles. Journal of Biogeography 39:476-487.

Gonzalez, O. J., and D. R. Zak. 1996. Dry forests of St. Lucia, West Indies: vegetation and soil properties. Biotropica 28:618-626.

Graveson, R. 2009. The classification of the vegetation of Saint Lucia. Technical Report No. 3 to the National Forest Demarcation and Bio-Physical Resource Inventory Project, FCG International Ltd, Helsinki, Finland.

Graveson, R., and M. Smith. 2013. Plants of Saint Lucia. Accessed at $<$ http://www.saint lucianplants.com/ $>$. 
Grouard, S. 2001. Faunal remains associated with Late Saladoïd and Post-Saladoïd occupations Anse à la Gourde, Guadeloupe, West Indies: preliminary results. Archaeofauna 10:71-98.

Hall, E. R. 1946. Mammals of Nevada. University of California Press, Berkeley. xi $+710 \mathrm{pp}$.

Harmsen, J., G. Ellis, and R. J. Devaux. 2012. A history of St. Lucia. Lighthouse Road Publications, St. Lucia. 438 pp.

Herrera, L. G., E. Gutierrez, K. A. Hobson, B. Altube, W. G. Diaz, and V. Sanchez-Cordero. 2002. Sources of assimilated protein in five species of New World frugivorous bats. Oecologia 133:280-287.

Herrera, L. G., K. A. Hobson, L. M. Miron, N. P. Ramirez, G. C. Mendez, and V. Sanchez-Codero. 2001. Sources of protein in two species of phytophagous bats in a seasonal dry forest: evidence from stable-isotope analysis. Journal Mammalogy 82:352-361.

Hilton, G. M., P. W. Atkinson, G. A. L. Gray, W. J. Arendt, and D. W. Gibbons. 2003. Rapid decline of the volcanically threatened Montserrat oriole. Biological Conservation 111:79-89. https://doi.org/10.1016/S00063207(02)00252-5.

Hodell, D. A., J. H. Curtis, G. A. Jones, A. Higuera-Gundy, M. Brenner, M. W. Binford, and K. T. Dorsey. 1991. Reconstruction of Caribbean climate change over the past 10,500 years. Nature 352:790-793.

Hood, C. S., and J. K. Jones, Jr. 1984. Noctilio leporinus. Mammalian Species 216:1-7.

Husson, A. M. 1962. The bats of Suriname. Rijksmuseum van Natuurlijke Historie te Leiden, Zoologische verhandelingen 58:1-282.

Isaac, C., and C. P.-A. Bourque. 2001. Ecological life zones of Saint Lucia. Global Ecology and Biogeography 10:549-566.

Issartel, G., and F. Leblanc. 2004. Contribution à l'inventaire des chiroptères de Martinique. Direction Régionale de l'Environnement, Martinique. 63 pp.

Jeschke, J. M., and D. L. Strayer. 2005. Invasion success of vertebrates in Europe and North America. Proceedings of the National Academy of Sciences of the USA 102:7198-7202.

JMP 12. 2015. SAS Institute Inc., Cary, North Carolina.

Jones, J. K., Jr. 1978. A new bat of the genus Artibeus from the Lesser Antillean island of St. Vincent. Occasional Papers, Museum of Texas Tech University 51:1-6.

Jones, J. K., Jr., and C. J. Phillips. 1970. Comments on the systematics and zoogeography of the bats in the Lesser Antilles. Studies on the Fauna of Curaçao and other Caribbean Islands 32:131-145.

Jones, J. K., Jr., and C. J. Phillips. 1976. Bats of the genus Sturnira in the Lesser Antilles. Occasional Papers, Museum of Texas Tech University 40:1-16.
Jones, J. K., Jr., and A. Schwartz. 1967. Bredin-ArchboldSmithsonian Biological Survey of Dominica. 6. Synopsis of bats of the Antillean genus Ardops. Proceedings of the United States National Museum 124(3634):1-13.

Jones, K. E., K. E. Barlow, N. Vaughan, A. Rodríguez-Durán, and M. R. Gannon. 2001. Short-term impacts of extreme environmental disturbance on the bats of Puerto Rico. Animal Conservation 4:59-66.

Jones, K. E., A. Purvis, and J. L. Gittleman. 2003. Biological correlates of extinction risk in bats. American Naturalist 161:601-614.

Khan, F. A. A., C. D. Phillips, and R. J. Baker. 2014. Timeframes of speciation, reticulation, and hybridization in the bulldog bat explained through phylogenetic analyses of all genetic transmission elements. Systematic Biology 63:96-110.

Kimber, C. T. 1988. Martinique revisited: the changing plant geographies of a West Indian island. Texas A\&M University Press, College Station. $x x+458 \mathrm{pp}$

Koopman, K. F. 1968. Taxonomic and distributional notes on Lesser Antillean bats. American Museum Novitates 2333:1-13.

Koopman, K. F. 1976. Zoogeography. Pp. 39-47 in Biology of bats of the New World family Phyllostomatidae, Part I (R. J. Baker, J. K. Jones, Jr., and D. C. Carter, eds.). Special Publications, Museum of Texas Tech University 10:1-218.

Koopman, K. F. 1983. Two general problems involved in systematics and zoogeography of bats. Pp. 412-415 in Advances in herpetology and evolutionary biology. Essays in honor of Ernest E. Williams (A. G. J. Rhodin and K. Miyata, eds.). Museum of Comparative Zoology, Cambridge. 725 pp.

Krutzch, P. H., and D. W. Nellis. 2006. Reproductive anatomy and cyclicity of the male bat Brachyphylla cavernarum (Chiroptera: Phyllostomidae). Acta Chiropterologica 8:497-507.

Kwiecinski, G. G., S. C. Pedersen, H. H. Genoways, P. A. Larsen, R. J. Larsen, J. D. Hoffman, F. Springer, C. J. Phillips, and R. J. Baker. 2018. Bats of Saint Vincent, Lesser Antilles. Special Publications, Museum of Texas Tech University 68:1-68.

Lack, D. 1976. Island biology: illustrated by the land birds of Jamaica. University of California Press, Berkeley and Los Angeles. xvi +445 pp.

Lamichhaney, S., F. Han, M. T. Webster, L. Andersson, B. R. Grant, and P. R. Grant. 2018. Rapid hybrid speciation in Darwin's finches. Science 359(6372):224-228.

Lang, A. B., C. D. Weise, E. K. V. Kalko, and H. Roemer. 2004 The bias of bat netting. Bat Research News 45:235.

Larsen, P. A., S. R. Hoofer, M. C. Bozeman, S. C. Pedersen, H. H. Genoways, C. J. Phillips, D. E. Pumo, and R. J. Baker. 2007. Phylogenetics and phylogeography of the Artibeus 
jamaicensis complex based on the cytochrome- $b$ DNA sequence. Journal of Mammalogy 88:712-727.

Larsen, P. A., M. R. Marchán-Rivadeneira, and R. J. Baker. 2010. Natural hybridization generates mammalian lineage with species characteristics. Proceedings of the National Academy of Sciences of the USA 107:11447-11452.

Larsen, P. A., M. R. Marchán-Rivadeneria, and R. J. Baker. 2013. Speciation dynamics of the fruit-eating bats (genus Artibeus): evidence of ecological divergence in Central American populations. Pp. 315-339 in Bat Evolution, Ecology, and Conservation (R. A. Adams and S. C. Pedersen, eds.). Springer, New York. 547 pp.

Larsen, P. A., L. Stiles, S. C. Pedersen, and G. G. Kwiecinski. 2011. A new species of Micronycteris (Chiroptera: Phyllostomidae) from Saint Vincent, Lesser Antilles. Mammalian Biology 76:687-700.

Larsen, R. J., K. Boegler, H. H. Genoways, W. Masefield, R. Kirsch, and S. C. Pedersen. 2007. Mist netting bias, species accumulation curves, and rediscovery of two bats on Montserrat. Acta Chiropterologica 9:423-435.

Larsen, R. J., P. A. Larsen, H. H. Genoways, F. M. Catzeflis, K. Geluso, G. G. Kwiecinski, S. C. Pedersen, F. Simal, R. J. Baker. 2012. Evolutionary history of Caribbean species of Myotis, with evidence of a third Lesser Antillean endemic. Mammalian Biology 77:124-134.

Larsen, R. J., P. A. Larsen, C. D. Phillips, H. H. Genoways, G G. Kwiecinski, S. C. Pedersen, C. J. Phillips, and R. J. Baker. 2017. Patterns of morphological and molecular evolution in the Antillean tree bat, Ardops nichollsi (Chiroptera: Phyllostomidae). Occasional Papers, Museum of Texas Tech University 345:1-28.

LaVal, R. K. 1973. Observations on the biology of Tadarida brasiliensis cynocephala in southeastern Louisiana. American Midland Naturalist 89:112-120.

LaVal, R. K. 2004. Impact of global warming and locally changing climate on tropical cloud forest bats. Journal of Mammalogy 85:237-244.

Lawlor, T. E. 1986. Comparative biogeography of mammals on islands. Pp. 99-125 in Island biogeography of mammals (L. R. Heaney and B. D. Patterson, eds.). Academic Press, New York. 271 pp.

Lefort de Latour, J.-F. 1787. Description générale et particulière de l'isle de Ste-Lucie en 1784. Sainte-Lucie, Fille de la Martinique.

Lenoble, A., B. Angin, J-B. Huchet, and A. Royer. 2014a. Seasonal insectivory of the Antillean fruit bat (Brachyphylla cavernarum). Caribbean Journal of Science 48:127-131.

Lenoble, A., C. Bochaton, T. Bos, E. Discamps, and A. Queffelec. 2014b. Predation of Lesser naked-backed bats by a pair of American Kestrels on the Island of Marie-Galante, French West Indies. Journal Raptor Research 48:78-81.
Lewis-Oritt, N., C. A. Porter, and R. J. Baker. 2001a. Molecular systematics of the family Mormoopidae (Chiroptera) based on cytochrome- $b$ and recombination activating gene 2 sequences. Molecular Phylogenetics and Evolution 20:426-436.

Lewis-Oritt, N., R. A. Van Den Bussche, and R. J. Baker. 2001b. Molecular evidence for evolution of piscivory in Noctilio (Chiroptera: Noctilionidae). Journal of Mammalogy 82:748-759.

Lindsay, J., J. David, J. Shepard, and J. Ephraim. 2002. Scientific supplement to the volcanic hazard assessment for Saint Lucia, Lesser Antilles. St. Augustine, University of the West Indies, Seismic Research Unit, Trinidad and Tobago. iii $+60 \mathrm{pp}$.

Lindsay, K. C., G. G. Kwiecinski, S. C. Pedersen, J.-P. Bacle, and H. H. Genoways. 2010. First record of Ardops nichollsi from Antigua, Lesser Antilles. Mammalia 74:93-95.

Lindsey, L. L., and L. K. Ammerman. 2016. Patterns of genetic diversification in a widespread species of bat, Molossus molossus. Occasional Papers, Museum of Texas Tech University 339:1-15.

Lockwood, J. L., P. Cassey, and T. M. Blackburn. 2005. The role of propagule pressure in explaining species invasions. Trends in Ecology and Evolution 20:223-228.

Lockwood, J. L., P. Cassey, and T. M. Blackburn. 2009. The more you introduce the more you get: the role of colonization pressure and propagule pressure in invasion ecology. Diversity and Distribution 15:904-910.

Lomolino, M. V. 1986. Mammalian community structure on islands: immigration, extinction and interactive effects. Biological Journal of the Linnean Society 28:1-21.

Lucek, K., A. Sivasundar, and O. Seehausen. 2012. Evidence of adaptive evolutionary divergence during biological invasion. Public Library of Science ONE 7(11): e49377. https://doi.org/10.1371/journal.pone.0049377.

MacArthur, R. H., and E. O. Wilson. 1967. The theory of island biogeography. Princeton University Press, Princeton, New Jersey. $x i+203$ pp.

Malaizé, B., P. Bertran, P. Carbonel, D. Bonnissent, K. Charlier, D. Galop, D. Imbert, N. Serrand, C. Stouvenot, and C. Pujol. 2011. Hurricanes and climate in the Caribbean during the past 3700 years BP. Holocene 21:911-924.

Marinello, M. M., and E. Bernard. 2014. Wing morphology of Neotropical bats: a quantitative and qualitative analysis with implications for habitat use. Canadian Journal of Zoology 92:141-147.

Masson, D., M. Breuil, and A. Breuil. 1990. Premier inventaire des chauves-souris de l'île de Marie-Galante (Antilles Françaises). Mammalia 54:656-658.

Mathews T. J., F. Guilhaumon, K. A. Triantis, M. K. Borregaard, and R. J. Whittaker. 2015. On the form of the species-area 
relationships in habitat islands and true islands. Global Ecology and Biogeography 25:847-858.

McCarthy, T. J., and R. W. Henderson. 1992. Confirmation of Ardops nichollsi on Marie-Galante, Lesser Antilles, and comments on other bats. Caribbean Journal of Science 28:106-107.

Meyer, C. F., L. M. Aguiar, L. F. Aguirre, et al. 2011. Accounting for detectability improves estimates of species richness in tropical bat surveys. Journal of Applied Ecology 48:777-787.

Meyer, C. F., L. M. Aguiar, J. Baumgarten, et al. 2015. Species undersampling in tropical bat surveys: effects on emerging biodiversity patterns. Journal of Animal Ecology 84:113-123.

Miller, G. S., Jr. 1902. Twenty new American bats. Proceedings of the Academy of Natural Sciences of Philadelphia 54:389-412.

Miller, G. S., Jr. 1913a. Five new mammals from tropical America. Proceedings of the Biological Society of Washington 26:31-34.

Miller, G. S., Jr. 1913b. Notes on bats of the genus Molossus. Proceedings of the United States National Museum 46:85-92.

Minitab 17. 2010. Statistical Software. State College, Pennsylvania.

Morton, M. N. 2009. Management of critical species on Saint Lucia: species profiles and management recommendations. Technical Report No. 13 to the National Forest Demarcation and Bio-Physical Resource Inventory Project, FCG International Ltd, Helsinki, Finland.

Newman, W. R. 1965. A report of general and economic geological studies, St. Lucia, West Indies. United Nations Programme of Technical Assistance. 43 pp.

Newsom, L. A., and E. S. Wing. 2004. On Land and Sea: Native American uses of biological resources in the West Indies. University of Alabama Press, Tuscaloosa, AL. xviii +323 pp.

Norberg, U. M., and J. M. V. Rayner. 1987. Ecological morphology and flight in bats (Mammalia; Chiroptera): wing adaptations, flight performance, foraging strategy, and echolocation. Philosophical Transactions of the Royal Society B 316:335-427.

Olson, S. L., and A. M. Nieves-Rivera. 2010. Fossil evidence and probable extinction of the greater fishing bat Noctilio leporinus (Chiroptera: Noctilionidae) on Isla de Mona, Puerto Rico. Mastozoologica Neotropical 17:167-170.

Orihuela, J., and A. Tejedor. 2015. Report of Peter's ghost faced bat Mormoops megalophylla fossils from the island of Barbuda, Lesser Antilles. Chiroptera Neotropical 21:1338-1341.
Orr, T. J., J. Ortega, R. A. Medellin, C. D. Sánchez, and K. A. Hammond. 2016. Diet choice in frugivorous bats: gourmets or operational pragmatists? Journal of Mammalogy 97:1578-1588.

Owen, R. D., R. K. Chesser, and D. C. Carter. 1990. The systematic status of Tadarida brasiliensis cynocephala and Antillean members of the Tadarida brasiliensis group, with comments on the generic name Rhizomops Legendre. Occasional Papers, Museum of Texas Tech University 133:1-18.

Paine, R. T. 1977. Controlled manipulations in the marine intertidal zone, and their contributions to ecological theory. Special Publications of the Academy of Natural Sciences of Philadelphia 12:245-270.

Patiño, J., R. J. Whittaker, P. A. V. Borges, et al. 2017. A roadmap for island biology: 50 fundamental questions after 50 years of the theory of island biogeography. Journal of Biogeography 44:963-983.

Patterson, B. D., and W. Atmar. 1986. Nested subsets and the structure of insular mammalian faunas and archipelagos. Biological Journal of the Linnean Society 28:65-82.

Patterson, B. D., M. R. Willig, and R. D. Stevens. 2003. Trophic strategies, niche partitioning, and patterns of ecological organization. Pp. 536-579 in Bat ecology (T. H. Kunz and M. B. Fenton, eds.). University of Chicago Press, Chicago, Illinois. xix +779 pp.

Pavan, A. C., and G. Marroig. 2016. Integrating multiple evidences in taxonomy: species diversity and phylogeny of mustached bats (Mormoopidae: Pteronotus). Molecular Phylogenetics and Evolution 103:184-198.

Pavan, A. C., F. M. Martins, and J. S. Morgante. 2013. Evolutionary history of bulldog bats (genus Noctilio): recent diversification and the role of the Caribbean in Neotropical biogeography. Biological Journal of the Linnaean Society 108:210-224.

Pedersen, S. C., H. H. Genoways, and P. W. Freeman. 1996 Notes on the bats from Montserrat (Lesser Antilles), with comments concerning the effects of Hurricane Hugo. Caribbean Journal of Science 32:206-213.

Pedersen, S. C., H. H. Genoways, G. G. Kwiecinski, P. A. Larsen, and R. J. Larsen. 2013 (c2012). Biodiversity, biogeography, and conservation of bats in the Lesser Antilles. Pp. 62-73, 330 in Biodiversité insulaire: la flore, la faune et l'homme dans les Petites Antilles (J.-L. Vernier and M. Burac, eds.). Schoelchers, Martinique, Direction de l'Environnement, de l'Aménagement et du Logement de Martinique et Université des Antilles et de la Guyane, France. 335 pp.

Pedersen, S. C., H. H. Genoways, M. N. Morton, J. W. Johnson, and S. E. Courts. 2003. Bats of Nevis, northern Lesser Antilles. Acta Chiropterologica 5:251-267. 
Pedersen, S. C., H. H. Genoways, M. N. Morton, G. G. Kwiecinski, and S. E. Courts. 2005. Bats of St. Kitts (St. Christopher), northern Lesser Antilles, with comments regarding capture rates of Neotropical bats. Caribbean Journal of Science 41:744-760.

Pedersen, S. C., H. H. Genoways, M. N. Morton, V. J. Swier, P. A. Larsen, K. C. Lindsay, R. A. Adams, and J. D. Appino. 2006. Bats of Antigua, northern Lesser Antilles. Occasional Papers, Museum of Texas Tech University 249:1-18.

Pedersen, S. C., G. G. Kwiecinski, P. A. Larsen, M. N. Morton, R. A. Adams, H. H. Genoways, and V. J. Swier. 2010 (c2009). Bats of Montserrat: population fluctuation and response to hurricanes and volcanoes, 1978-2005. Pp. 302-340 in Island bats: evolution, ecology, and conservation (T. H. Fleming and P. A. Racey, eds.). University of Chicago Press, Chicago, Illinois. 549 pp.

Pedersen, S. C., P. A. Larsen, H. H. Genoways, M. N. Morton, K. C. Lindsay, and J. Cindric. 2007. Bats of Barbuda, northern Lesser Antilles. Occasional Papers, Museum of Texas Tech University 271:1-19.

Pedersen, S. C., P. A. Larsen, S. A. Westra, E. van Norren, W. Overman, G. G. Kwiecinski, and H. H. Genoways. 2018. Bats of Sint Eustatius, Caribbean Netherlands. Occasional Papers, Museum of Texas Tech University 353:1-24.

Pedersen, S. C., T. E. Popowics, G. G. Kwiecinski, and D. E. B. Knudsen. 2012. Pathology in phyllostomid fruit bats associated with volcanic ash fall on Montserrat. Journal of Mammalogy 93:1380-1392.

Pelletier, M., E. Stoetzel, D. Cochard, and A. Lenoble. 2017. Sexual dimorphism in the pelvis of Antillean fruit-eating bat (Brachyphylla cavernarum) and its application to a fossil accumulation from the Lesser Antilles. Geobios 50:311-318.

Phillips, C. J., D. E. Pumo, H. H. Genoways, and P. E. Ray. 1989. Caribbean island zoogeography: a new approach using mitochondrial DNA to study Neotropical bats. Pp. 661-684 in Biogeography of the West Indies: past, present, and future (C. A. Woods, ed.). Sandhill Crane Press, Gainesville, Florida. 878 pp.

Phillips, C. J., D. E. Pumo, H. H. Genoways, P. E. Ray, and C. A. Briskey. 1991. Mitochondrial DNA evolution and phylogeography in two Neotropical fruit bats, Artibeus jamaicensis and Artibeus lituratus. Pp. 97-123 in Latin American mammalogy, history, biodiversity, and conservation (M. A. Mares and D. J. Schmidly, eds.). University of Oklahoma Press, Norman. 468 pp.

Pregill, G. K., D. W. Steadman, S. L. Olson, and F. V. Grady. 1988. Late Holocene fossil vertebrates from Burma Quarry, Antigua, Lesser Antilles. Smithsonian Contributions to Zoology 463:1-27.

Pregill, G. K., D. W. Steadman, and D. R. Watters. 1994. Late Quaternary vertebrate faunas of the Lesser Antilles: his- torical components of Caribbean biogeography. Bulletin of the Carnegie Museum of Natural History 30:1-51.

Presley, S. J., M. R. Willig, and K. E. Jones. 2008. Composition and structure of Caribbean bat (Chiroptera) assemblages: effects of inter-island distance, elevation, and hurricaneinduced disturbance. Global Ecology and Biogeography 17:747-757.

Presley, S. J. and M. R. Willig. 2010. Bat metacommunity structure on Caribbean islands and the role of endemics. Global Ecology and Biogeography 19:185-199.

Pulliam, H. R. 1988. Sources, sinks, and population regulation. American Naturalist 132:652-661.

Pumo, D. E., E. Z. Golden, B. Elliot, C. J. Phillips, and H. H. Genoways. 1988. Mitochondrial DNA polymorphism in three Antillean island populations of the fruit bat, Artibeus jamaicensis. Molecular Biology and Evolution 5:79-89.

Pumo, D. E., I. Kim, J. Remsen, C. J. Phillips, and H. H. Genoways. 1996. Molecular systematics of the fruit bat, Artibeus jamaicensis: origin of an unusual island population. Journal of Mammalogy 77:491-503.

R Development Core Team. 2008. Statistical Software. Vienna, Austria.

Richardson, D. M., Pyšek, M. Rejmánek, M. G. Barbour, F. D. Panetta, and C. J. West. 2000. Naturalization and invasion of alien plants: concepts and definitions. Diversity and Distribution 6:93-107.

Rick, T. C., P. V. Kirch, J. M. Erlandson, and S. M. Fitzpatrick. 2013. Archeology, deep history, and the human transformation of island ecosystems. Anthropocene 4:33-45.

Ricklefs, R. E., and E. Bermingham. 2004. History and the species-area relationship in Lesser Antillean birds. The American Naturalist 163:227-239.

Ricklefs, R. E., and I. J. Lovette. 1999. The roles of island area per se and habitat diversity in the species-area relationships of four Lesser Antillean faunal groups. Journal of Animal Ecology 68:1142-1160.

Rodríguez-Durán, A. 2010 (c2009). Bat assemblages in the West Indies: the roles of caves. Pp. 265-280 in Island bats: evolution, ecology, and conservation (T. H. Fleming and P. A. Racey, eds.). University of Chicago Press, Chicago, Illinois. 549 pp.

Rodríguez-Durán, A., and T. H. Kunz. 2001. Biogeography of West Indian bats: an ecological perspective. Pp. 355-368 in Biogeography of the West Indies, patterns and perspectives (C. A. Woods and F. E. Sergile, eds.). CRC Press, Washington, DC. $582 \mathrm{pp}$.

Rojas, D., A. Vale, V. Ferrero, and L. Navarro. 2011. When did plants become important to leaf-nosed bats? Diversification of feeding habits in the family Phyllostomidae. Molecular Ecology 20:2217-2228.

Roobol, M. J., J. V. Wright, and A. L. Smith. 1983. Calderas or gravity slide structures in the Lesser Antilles island 
arc. Journal of Volcanology and Geothermal Research 19:121-134.

Royer, A., B. Malaizé, C. Lécuyer, A. Queffelec, K. Charlier, T. Caley, and A. Lenoble. 2017. A high-resolution temporal record of environmental changes in the eastern Caribbean (Guadeloupe) from 40 to $10 \mathrm{ka}$ BP. Quaternary Science Reviews 155:198-212.

Schmidt, M. W., and H. J. Spero. 2011. Meridional shifts in the marine ITCZ and the tropical hydrologic cycle over the last three glacial cycles. Paleoceanography and Paleoclimatology 6:PA1206, https://doi.org/10.1029/2010PA001976.

Schwartz, A. 1955. The status of the species of the brasiliensis group of the genus Tadarida. Journal of Mammalogy 36:106-109.

Schwartz, A., and J. K. Jones, Jr. 1967. Bredin-ArchboldSmithsonian Biological Survey of Dominica. 7. Review of bats of the endemic Antillean genus Monophyllus. Proceedings of the United States National Museum 124(3635): 1-20.

Shamel, H. H. 1931. Notes on the American bats of the genus Tadarida. Proceedings of the United States National Museum 78(19):1-27.

Siegel, P. E., J. G. Jones, D. M. Pearsall, N. P. Dunning, P. Farrell, N. A. Duncan, J. H. Curtis, and S. K. Singh. 2015. Paleoenvironmental evidence for first human colonization of the eastern Caribbean. Quaternary Science Reviews 129:275-295

Simberloff, D. S. 1978. Using island biogeographic distribution to determine if colonization is stochastic. American Naturalist 112:713-726.

Simberloff, D. S. 1980. Dynamic equilibrium island biogeography: the second stage. Pp. 1289-1295 in Acta XVII Congressus Internationalis Ornithologici, 2 (R. Nohring, ed.). Deutschen Ornithologen-Gesellschaft, Berlin. 1463 pp.

Simberloff, D. S. 2009. The role of propagule in biological invasions. Annual Review of Ecology, Evolution, and Systematics 40:81-102.

Simmons, N. B. 2005. Order Chiroptera. Pp. 312-529 in Mammal species of the world: a taxonomic and geographic reference, 3rd ed. (D. E. Wilson and D. M. Reeder, eds.). John Hopkins University Press, Baltimore, Maryland. $\mathrm{xxxv}+2142 \mathrm{pp}$.

Simmons, N. B., and R. S. Voss. 1998. The mammals of Paracou, French Guiana, a Neotropical lowland rainforest fauna. Part 1, Bats. Bulletin of the American Museum of Natural History 237:1-219.

Smith, J. D. 1972. Systematics of the chiropteran family Mormoopidae. Miscellaneous Publication of the Museum of Natural History, University of Kansas 56:1-132.

Snow, J. T., A. L. Wyatt, A. K. McCarthy, and E. K. Bishop. 1995. Fallout of debris from tornadic thunderstorms: a historical perspective and two examples from VORTEX. Bulletin of the American Meteorological Society 76:1777-1790.

Soto-Centeno, J. A., N. B. Simmons, and D. W. Steadman. 2017. The bat community of Haiti and evidence for its long-term persistence at high elevations. Public Library of Science One 12(6): e0178066, https://doi.org/10.1371/ journal.pone. 0178066

Soto-Centeno, J. A., and D. W. Steadman. 2015. Fossils reject climate change as the cause of extinction of Caribbean bats. Science Reports 5:7971.

Speer, K. A., B. J. Petronio, N. B. Simmons, R. Richey, K. Magrani, J. A. Soto-Centeno, and D. L. Reed. 2017. Population structure of a widespread bat (Tadarida brasiliensis) in an island system. Ecology and Evolution 7:7585-7598.

Steadman, D. W., N. A. Albury, B. Kakuk, J. I. Mead, J. A. Soto-Centeno, H. M. Singleton, and J. Frankling. 2015. Vertebrate community on an ice-age Caribbean island. Proceedings of the National Academy of Sciences of the USA 112:44 E5963-E5971.

Steadman, D. W., G. K. Pregill, and S. L. Olson. 1984b. Fossil vertebrates from Antigua, Lesser Antilles: evidence for late Holocene human-caused extinctions in the West Indies. Proceedings of the National Academy of Science of the USA 81:4448-4451.

Steadman, D. W., D. R. Watters, E. J. Reitz, and G. K. Pregill. 1984a. Vertebrates from archeological sites on Montserrat, West Indies. Annals of the Carnegie Museum $53: 1-29$.

Steinbauer, M. J. 2017. A generalization of the taxon cycle. Journal of Biogeography 44:1110-1112.

Steinbauer, M. J., F. Field, J-A. Grytnes, et al. 2016. Topography-driven isolation, speciation, and a global increase of endemism with elevation. Global Ecology and Biogeography 25:1097-1107.

Stoetzel, E., A. Royer, D. Cochard, and A. Lenoble. 2016. Late Quaternary changes in bat palaeobiodiversity and palaeobiogeography under climatic and anthropogenic pressure: new insights from Marie-Galante, Lesser Antilles. Quaternary Science Review 143:150-174.

Swanepoel, P., and H. H. Genoways. 1978. Revision of the Antillean bats of the genus Brachyphylla (Mammalia: Phyllostomatidae). Bulletin of the Carnegie Museum of Natural History 12:1-53.

Swanepoel, P., and H. H. Genoways. 1983. Brachyphylla cavernarum. Mammalian Species 205:1-6.

Tavares, V., O. Warsi, F. Balseiro, C. Mancina, and L. Dávalos. 2018. Out of the Antilles: fossil phylogenies support reverse colonization of bats to South America. Journal of Biogeography 45:859-873. 
Tejedor, A. 2006. The type locality of Natalus stramineus (Chiroptera: Natalidae): implications for the taxonomy and biogeography of the genus Natalus. Acta Chiropterologica 8:361-380.

Timm, R. M., and H. H. Genoways. 2003. West Indian mammals from the Albert Schwartz Collection: biological and historical information. Scientific Papers, Natural History Museum of the University of Kansas 29:1-47.

Tomblin, J. 1981. Earthquakes, volcanoes and hurricanes: a review of natural hazards and vulnerability in the West Indies. Ambio 10:340-344.

Toussaint, A., L. John, and M. Morton. 2009. The status and conservation of Saint Lucia's forest birds. Technical Report No. 12 to the National Forest Demarcation and Bio-Physical Resource Inventory Project, FCG International Ltd, Helsinki, Finland.

Trakhtenbrot, A., R. Nathan, G. Perry, and D. M. Richardson. 2005. The importance of long-distance dispersal in biodiversity conservation. Diversity and Distribution 11:173-181.

Tuck, L. M. 1968. Laughing Gulls (Larus atricilla) and Black Skimmers (Rynchops nigra) brought to Newfoundland by hurricane. Bird-Banding 39:200-208.

Valente, L., R. S. Etienne, and L. M. Dávalos. 2017. Recent extinctions disturb path to equilibrium diversity in Caribbean bats. Nature Ecology and Evolution 1:26, https:// doi.org/10.1038/s41559-016-0026.

Valéry, L., H. Fritz, J.-C. Lefeuvre, and D. Simberloff. 2008. In search of a real definition of biological invasion phenomenon itself. Biological Invasions 10:1345-1351.

Vaughan, N. 1995. New records of bats on St. Vincent. Bulletin of the British Ecological Society 26:102-104.

Vaughan, N., and J. E. Hill. 1996. Bat (Chiroptera) diversity and abundance in banana plantations and rain forest, and three new records for St. Vincent, Lesser Antilles. Mammalia 60:441-447.

Vaughan, N., S. Parsons, K. E. Barlow, and M. R. Gannon. 2004. Echolocation calls and wing morphology of bats from the West Indies. Acta Chiropterologica 6:75-90.

Velazco, P. M., and B. D. Patterson. 2013. Diversification of the yellow-shouldered bat, genus Sturnira (Chiroptera, Phyllostomidae), in the New World tropics. Molecular Phylogenetics and Evolution 68:683-698.

Vermeij, G. J. 1996. An agenda for invasion biology. Biological Conservation 78:3-9.

Versteeg, A.H., and K. Schinkel. 1992. The archaeology of St. Eustatius: the Golden Rock Site. Publication of the
Foundation for Scientific Research in the Caribbean Region, number 113, Amsterdam. 284 pp.

Waters, J. M. 2011. Competitive exclusion: phylogeography's "elephant in the room"? Molecular Ecology 20:4388-4394.

Welch, J., and C. Leppanen. 2017. The threat of invasive species to bats: a review. Mammal Review 47:277-290.

Whittaker, R. J. 1998. Island biogeography: ecology, evolution, and conservation. Oxford University Press, Oxford. $285 \mathrm{pp}$.

Wilkins, K. T. 1989. Tadarida brasiliensis. Mammalian Species $331: 1-10$.

Williamson, M., and A. Fitter. 1996. The varying success of invaders. Ecology 77:1661-1666.

Willig, M. R., S. J. Presley, C. P. Bloch, and H. H. Genoways. 2010 (c2009). Macroecology of Caribbean bats: effects of area, elevation, latitude, hurricane-induced disturbance. Pp. 216-264 in Island bats: evolution, ecology, and conservation (T. H. Fleming and P. A. Racey, eds.). University of Chicago Press, Chicago, Illinois. 549 pp.

Wilson, D. E. 1973. Reproduction in neotropical bats. Periodicum Biologorum 75:215-217.

Wilson, D. E. 1979. Reproductive pattern. Pp. 317-378 in Biology of bats of the New World family Phyllostomatidae, part III (R. J. Baker, J. K. Jones, Jr., and D. C. Carter, eds.). Special Publications, Museum of Texas Tech University 16:1-441.

Wilson, D. E., C. O. Handley, Jr., and A. L. Gardner. 1991. Reproduction on Barro Colorado Island. Pp. 43-52 in Demography and natural history of the common fruit bat, Artibeus jamaicensis, on Barro Colorado Island, Panamá (C. O. Handley, Jr., D. E. Wilson, and A. L. Gardner, eds.). Smithsonian Contributions in Zoology 511:iii + 1-173.

Wilson, S. M. 1989. The prehistoric settlement pattern of Nevis, West Indies. Journal of Field Archaeology 16:427-450.

Wohletz, K., G. Heiken, M. Ander, F. Goff, F-D. Vuataz, and G. Wadge. 1986. The Qualibou Caldera, St. Lucia, West Indies. Journal of Volcanology and Geothermal Research 27:77-115.

Wright, J. V., M. J. Roobol, A. L. Smith, R. S. J. Sparks, S. A. Brazier, W. I. Rose, and H. Sigurdsson. 1984. Late Quaternary explosive volcanism on St. Lucia, West Indies. Geological Magazine 121:1-15.

Wunderle, J. M., Jr. 1985. An ecological comparison of the avifauna of Grenada and Tobago, West Indies. Wilson Bulletin 97:356-365. 
Addresses of authors:

\section{Scott C. Pedersen}

Department of Biology and Microbiology

South Dakota State University

Brookings, SD 57007

scott.pedersen@sdstate.edu

\section{Gary G. KWIEcinSKI}

Department of Biology

University of Scranton

204 Monroe Avenue

Scranton, PA 18510

gary.kwiecinski@scranton.edu

\section{Hugh H. Genoways}

University of Nebraska State Museum

W436 Nebraska Hall

Lincoln, NE 68588

hgenoways1@unl.edu

\section{RoXanne J. LARSEN}

Department of Veterinary and Biomedical Sciences College of Veterinary Medicine

University of Minnesota

Saint Paul, MN 55108

rlarsen@umn.edu
Peter A. Larsen

Department of Veterinary and Biomedical Sciences College of Veterinary Medicine

University of Minnesota

Saint Paul, MN 55108

plarsen@umn.edu

\section{Carleton J. Phillips}

Department of Biological Sciences and Museum Texas Tech University

Lubbock, TX 79409

carl.phillips@ttu.edu

\section{Robert J. BaKer [DECEASED]}

Department of Biological Sciences and Museum Texas Tech University

Lubbock, TX 79409 


\begin{tabular}{|c|c|c|c|c|}
\hline \multicolumn{5}{|c|}{ APPENDIX } \\
\hline \multicolumn{5}{|c|}{$\begin{array}{l}\text { St. Lucia Gazetteer-The coordinates for collecting sites that we visited during our survey were determined by } \\
\text { using a Garmin eTrex handheld GPS system. Coordinates for sites where other collectors conducted the work } \\
\text { were taken from the specimens, published records, or other reference material, including online St. Lucia gazet- } \\
\text { teers and maps. }\end{array}$} \\
\hline Locality & Quarter & Latitude & Longitude & Elevation (m) \\
\hline Anse Chastanet & Soufrière & $13^{\circ} 52^{\prime} 00.9^{\prime \prime} \mathrm{N}$ & $61^{\circ} 04^{\prime} 10.3^{\prime \prime} \mathrm{W}$ & --- \\
\hline Anse La Raye & Anse La Raye & $13^{\circ} 56^{\prime} 30.3^{\prime \prime} \mathrm{N}$ & $61^{\circ} 02^{\prime} 28.2^{\prime \prime} \mathrm{W}$ & 1 \\
\hline "Anse La Raye" = Venus Estate & Anse La Raye & $13^{\circ} 55^{\prime} 14.7^{\prime \prime} \mathrm{N}$ & $61^{\circ} 01^{\prime} 12.1^{\prime \prime} \mathrm{W}$ & --- \\
\hline Au Leon Peak & Dennery & $13^{\circ} 57^{\prime} 14.4^{\prime \prime} \mathrm{N}$ & $60^{\circ} 54^{\prime} 07.1^{\prime \prime} \mathrm{W}$ & 319 \\
\hline Barre de l'Isle Ridge & Castries & $13^{\circ} 55^{\prime} 35.3^{\prime \prime} \mathrm{N}$ & $60^{\circ} 57^{\prime} 32.0^{\prime \prime} \mathrm{W}$ & 294 \\
\hline Black Bay & Vieux Fort & $13^{\circ} 44^{\prime} 36.0^{\prime \prime} \mathrm{N}$ & $60^{\circ} 58^{\prime} 55.5^{\prime \prime} \mathrm{W}$ & 100 \\
\hline Boguis & Dauphin & $14^{\circ} 00^{\prime} 41.7^{\prime \prime} \mathrm{N}$ & $60^{\circ} 55^{\prime} 08.6^{\prime \prime} \mathrm{W}$ & 35 \\
\hline Canelles River & Micoud & $13^{\circ} 46^{\prime} 59.6^{\prime \prime} \mathrm{N}$ & $60^{\circ} 54^{\prime} 53.1 " \mathrm{~W}$ & 10 \\
\hline Castries & Castries & $14^{\circ} 00^{\prime} 36.7^{\prime \prime} \mathrm{N}$ & $60^{\circ} 59^{\prime} 15.0^{\prime \prime} \mathrm{W}$ & 10 \\
\hline Cul de Sac River (near Deglos) & Castries & $13^{\circ} 58^{\prime} 29.1^{\prime \prime} \mathrm{N}$ & $60^{\circ} 58^{\prime} 36.0^{\prime \prime} \mathrm{W}$ & 34 \\
\hline Dennery River & Dennery & $13^{\circ} 54^{\prime} 34.6^{\prime \prime} \mathrm{N}$ & $60^{\circ} 54^{\prime} 16.2^{\prime \prime} \mathrm{W}$ & 11 \\
\hline Des Cartier Rainforest Trail & Micoud & $13^{\circ} 50^{\prime} 24.2^{\prime \prime} \mathrm{N}$ & $60^{\circ} 58^{\prime} 45.9^{\prime \prime} \mathrm{W}$ & --- \\
\hline Diamond Botanical Garden & Soufrière & $13^{\circ} 51^{\prime} 08.7^{\prime \prime} \mathrm{N}$ & $61^{\circ} 02^{\prime} 57.5^{\prime \prime} \mathrm{W}$ & 47 \\
\hline "Durocher" = Morne Durocher & Praslin & $13^{\circ} 52^{\prime} 34.4^{\prime \prime} \mathrm{N}$ & $60^{\circ} 56^{\prime} 12.5^{\prime \prime} \mathrm{W}$ & --- \\
\hline Edmund Forest Reserve & Soufrière & $13^{\circ} 50^{\prime} 31.8^{\prime \prime} \mathrm{N}$ & $61^{\circ} 00^{\prime} 16.0^{\prime \prime} \mathrm{W}$ & 550 \\
\hline Forestière Trail Head & Castries & $13^{\circ} 58^{\prime} 11.2^{\prime \prime} \mathrm{N}$ & $60^{\circ} 57^{\prime} 08.8^{\prime \prime} \mathrm{W}$ & 300 \\
\hline Fox Grove Inn & Praslin & $13^{\circ} 51^{\prime} 47.0^{\prime \prime} \mathrm{N}$ & $60^{\circ} 54^{\prime} 22.8^{\prime \prime} \mathrm{W}$ & 52 \\
\hline Grace Cave & Vieux Fort & $13^{\circ} 47^{\prime} 57.0^{\prime \prime} \mathrm{N}$ & $60^{\circ} 58^{\prime} 43.6^{\prime \prime} \mathrm{W}$ & 165 \\
\hline Mamiku River & Praslin & $13^{\circ} 52^{\prime} 02.8^{\prime \prime} \mathrm{N}$ & $60^{\circ} 54^{\prime} 05.0^{\prime \prime} \mathrm{W}$ & 3 \\
\hline Marigot Bay & Castries & $13^{\circ} 57^{\prime} 50.0^{\prime \prime} \mathrm{N}$ & $61^{\circ} 01^{\prime} 34.0^{\prime \prime} \mathrm{W}$ & 5 \\
\hline Marquis Estate & Dauphin & $14^{\circ} 01^{\prime} 35.2^{\prime \prime} \mathrm{N}$ & $60^{\circ} 54^{\prime} 40.6 " \mathrm{~W}$ & 25 \\
\hline Millet Forest (= Millet Bird Sanctuary) & Anse La Raye & $13^{\circ} 53^{\prime} 44.7^{\prime \prime} \mathrm{N}$ & $60^{\circ} 59^{\prime} 50.2^{\prime \prime} \mathrm{W}$ & --- \\
\hline Monchy & Dauphin & $14^{\circ} 03^{\prime} 10.7^{\prime \prime} \mathrm{N}$ & $60^{\circ} 56^{\prime} 03.2^{\prime \prime} \mathrm{W}$ & 25 \\
\hline near Piaye & Laborie & $13^{\circ} 46^{\prime} 05.1^{\prime \prime} \mathrm{N}$ & $61^{\circ} 01^{\prime} 54.6^{\prime \prime} \mathrm{W}$ & --- \\
\hline Piton Flore & Castries & $13^{\circ} 57^{\prime} 51.6^{\prime \prime} \mathrm{N}$ & $60^{\circ} 56^{\prime} 24.0^{\prime \prime} \mathrm{W}$ & 300 \\
\hline Quilesse & Micoud & $13^{\circ} 50^{\prime} 23.1^{\prime \prime} \mathrm{N}$ & $60^{\circ} 58^{\prime} 25.8^{\prime \prime} \mathrm{W}$ & 283 \\
\hline Raillon Negres & Praslin & $13^{\circ} 52^{\prime} 25.3^{\prime \prime} \mathrm{N}$ & $60^{\circ} 56^{\prime} 09.6^{\prime \prime} \mathrm{W}$ & 255 \\
\hline River Dorée & Choiseul & $13^{\circ} 46^{\prime} 05.1^{\prime \prime} \mathrm{N}$ & $61^{\circ} 01^{\prime} 54.6^{\prime \prime} \mathrm{W}$ & --- \\
\hline Saltibus & Laborie & $13^{\circ} 48^{\prime} 59.8^{\prime \prime} \mathrm{N}$ & $60^{\circ} 00^{\prime} 21.9^{\prime \prime} \mathrm{W}$ & 398 \\
\hline Sorcière River* & Dauphin & $14^{\circ} 01^{\prime} 26.0^{\prime \prime} \mathrm{N}$ & $60^{\circ} 54^{\prime} 33.2^{\prime \prime} \mathrm{W}$ & --- \\
\hline Soufrière Cave & Soufrière & $13^{\circ} 51^{\prime} 29.1^{\prime \prime} \mathrm{N}$ & $61^{\circ} 03^{\prime} 52.2^{\prime \prime} \mathrm{W}$ & 0 \\
\hline
\end{tabular}




\begin{tabular}{llccc}
\hline Locality & Quarter & Latitude & Longitude & Elevation $(\mathrm{m})$ \\
\hline Troumassee River & Micoud & $13^{\circ} 49^{\prime} 13.9^{\prime \prime} \mathrm{N}$ & $60^{\circ} 54^{\prime} 53.7^{\prime \prime} \mathrm{W}$ & 40 \\
Union Nature Trail & Castries & $14^{\circ} 01^{\prime} 14.2^{\prime \prime} \mathrm{N}$ & $60^{\circ} 57^{\prime} 41.8^{\prime \prime} \mathrm{W}$ & 18 \\
Union Agricultural and Research Station & Gros Islet & $14^{\circ} 02^{\prime} 00.0^{\prime \prime} \mathrm{N}$ & $60^{\circ} 58^{\prime} 00.0^{\prime \prime} \mathrm{W}$ & 30.5 \\
Woodlands Estate & Vieux Fort & $13^{\circ} 47^{\prime} 54.7^{\prime \prime} \mathrm{N}$ & $60^{\circ} 58^{\prime} 50.7^{\prime \prime} \mathrm{W}$ & 226 \\
\hline
\end{tabular}

*We did not plot the Sorcière River site on the map (Fig. 12) for the Artibeus jamaicensis x schwartzi hybrid because we are uncertain of its exact location. It is entered above exactly as reported by Clarke (2009), albeit converted from his UTM designation [13⒌ $\left.59^{\prime} 06.7^{\prime \prime} \mathrm{N}, 60^{\circ} 53^{\prime} 21.4^{\prime \prime} \mathrm{W}\right]$. This location is near our site in the Marquis Estate, Dauphin Quarter. 




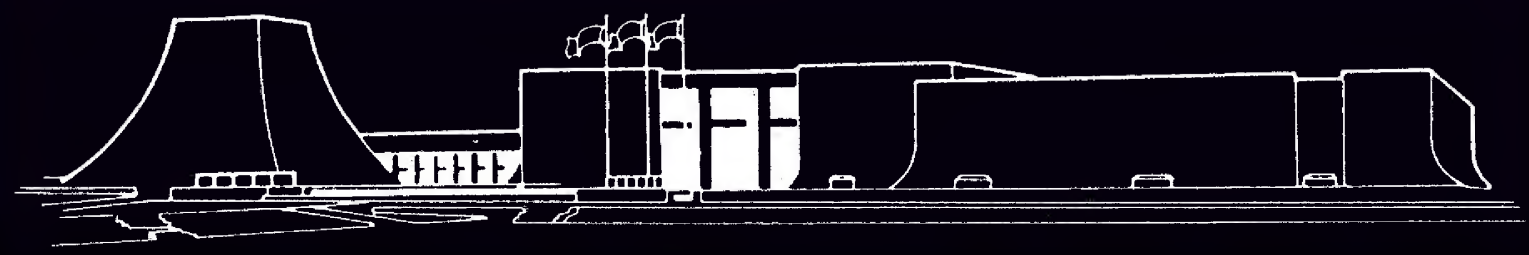

